UNIVERSIDADE DE SÃO PAULO - USP

ESCOLA DE COMUNICAÇÕES E ARTES - ECA

\title{
Poros - ou as passagens da comunicação
}

Tese apresentada ao Departamento de Jornalismo e Editoração da Escola de Comunicações e Artes da USP, para obtenção do grau de Doutora em Ciências da Comunicação, realizada sob orientação do Prof. Dr. Ciro J. R. Marcondes Filho.

Danielle Naves de Oliveira

São Paulo - Frankfurt am Main, 2006 
Para Michael 
" Terra a que me inclino sob o frio de minha testa que se alonga, e sinto mais presente quanto aspiro em ti o fumo antigo dos parentes, minha terra, me tens; e teu cativo passeias brandamente como ao que vai morrer se estende a vista de espaço luminosos, intocáveis: em mim o que resiste são teus poros. "

Carlos Drummond de Andrade

("Elegia", in Fazendeiro do ar, 1954) 


\section{Resumo}

A noção de poro é neste trabalho o fio condutor para pensar a comunicação. Palavra grega que quer dizer passagem, póros ( $\pi \square \square \square \square$ ) integra tanto o vocabulário dos mitos quanto o dos filósofos da pólis. Póros é passagem inédita, trajetória em mar aberto; portanto, não é caminho pré-traçado (ódos), participa de uma outra lógica, que aproxima o pensamento de sua própria margem, que põe continuamente a questão em questão. Com a ajuda deste fio condutor, o objetivo da presente tese é dissolver certos lugares-comuns que antecedem a pergunta "o que é comunicação?" e não exatamente respondê-la. Comunicar, como descrevem alguns manuais, pressupõe um solo comum e, a partir dele, tornar comum. Mas este solo merece atenção, pois não se sabe até hoje se o que está em questão é um habitar (ethos), um mover-se nômade pelo mundo ou uma troca de vivências ou símbolos. Lugares-comuns, lugares em comum: do imediato ao medium, do sujeito à mensagem, da vida privada ao espaço público, o que se tem são ainda pares metafísicos que não levam à elucidação, mas sim à aporia $(\square \pi \square \square \square \square)$ comunicativa. E aporias não se resolvem pelo método, mas pelo movimento do poro. Segundo esta perspectiva, comunicar tem a ver tanto com o pátrio, ordinário e comum, quanto com o desterro e o extraordinário (das Unheimliche).

A pesquisa foi realizada em duas fases: primeiramente no grupo temático FILOCOM (Estudos Filosóficos da Comunicação) na ECA-UsP e, em seguida, em estágio de 16 meses na Universidade J. W. Goethe de Frankfurt. No período brasileiro, contou-se com bolsa de doutorado da FAPESP e, no período alemão, com bolsa do convênio CAPES-DAAD.

\section{Sobre a autora}

Danielle Naves de Oliveira nasceu em São Paulo no dia 5 de novembro de 1975. Formou-se em jornalismo em 1997 pela Universidade Federal de Mato Grosso do Sul. Em 1998 ingressou na pós-graduação da Escola de Comunicação e Artes da USP onde, três anos depois, obteve o título de mestre em Ciências da Comunicação. Também na USP, foi aluna de graduação em filosofia a partir de 2001; curso seguido durante quatro anos, porém não concluído. Entre 2001 e 2003 foi docente contratada em instituições de ensino superior. De agosto de 2002 a novembro de 2006, seguiu o doutorado no Departamento de Jornalismo da ECA-UsP. 


\begin{abstract}
The idea of pore drives this work to a way of thinking communication. It is a Greek word that means passageway $(\pi \square \square \square \square)$ and comes both from mythology and philosophy. Pores is unhackneyed passage, path into open ocean: it is not a previewed path (ódos) then. It takes part in a different logic, that questions about the question itself, as it is a thought around hem - an edged thought. Going through this sense the thesis shall break down foregone commonplaces usual to "what is communication?" question, not answering it nevertheless. Communication, as it is supposed in research guides, comes from a common ground towards a sharing state, the common itself. One must pay attention to this ground, though, since it is not clear so far what it is about: an inhabitance (ethos), a nomadic moving around the world or yet a sharing of symbols and experience? Commonplaces, places in common: from prompt to the medium; from subject to message; from private life to public space. Does not matter what pair is taken since it is all about metaphysics, which does not quite lead to clarification but to communicative aporia. Nonetheless, aporias cannot be settled thru method, though only thru pores moving. According to this viewpoint, communication has got to have as much to do with home, common and ordinary as it has with desertion and uncanny (das Unheimliche).

This work was done in two stages: firstly in Filocom working group (Philosophical Studies of Communication) at Eca-UsP; secondly, in a 16 months period at J. W. Goethe University of Frankfurt. In Brazilian stage there was a grant from FAPESP and in German period there was a grant from CAPES-DAAD agreement.
\end{abstract}




\section{Agradecimentos}

Rastros, traços sutis, também fazem parte de um texto de doutorado. Rastros deixados por pessoas que silenciaram quando necessário, que abraçaram, que se rebelaram, que se revelaram, que ouviram, que falaram. Rastros que hoje se misturam ao cheiro dos livros, sempre os mesmos, anotados e amontoados em lugares inconvenientes da casa. Benjamin disse certa vez que "a obra é a máscara mortuária da concepção"; sim, a obra é o que fica de um pensamento que já foi movente, que já tirou o sono, que foi discutido e pensado em voz alta, rasurado, reescrito. Esta obra é o que fica de um tempo particular, intenso e vivo, graças à presença - próxima ou separada por um oceano - de gente insubstituível, de sua amizade.

Nestas páginas há rastros consideráveis de meu orientador, Ciro Marcondes Filho, a quem agradeço por seu incentivo permanente, por seu vigor e sua delicadeza no pensar, sua musicalidade, seu diálogo.

Sou também grata ao professor Manfred Faßler, que me acolheu em seu grupo de pesquisas na Universidade de Frankfurt.

Ao professor Norval Baitello Jr. e a todos os integrantes do CisC, com os quais tenho partilhado ao longo de alguns anos as interrogações e alegrias da Cultura.

Aos colegas do FILOCOM, pela troca vivaz; especialmente a Marco Toledo Bastos, pelo debate danificações/marcações, levado sistematicamente em torno de nossas dúvidas e idéias.

À professora Jerusa Pires Ferreira, por seu voto de confiança e estímulo.

Não posso deixar de fazer referência às aulas da professora Olgária C. F. Matos, no Departamento de Filosofia da USP, onde me foram sopradas pistas importantes sobre as questões da cidade, dos mitos e das tragédias.

A minha mãe e irmãos, Maria, Cibelle e Davi, por estarem sempre presentes e, de maneira especial, a meu sobrinho Pedro. Também a meu pai, Daniel, por ter me deixado como herança a inquietude.

A Wolfgang e Waltraud Schröder, pelo carinho e acolhimento familiar.

Por fim, gratidão infinita para aquele que me ajudou a encontrar forças contra a melancolia do inverno alemão, meu marido Michael Schröder.

A pesquisa foi financiada, no período brasileiro, pela FAPESP e, no período alemão, pela CAPES e pelo DAAD. A estas instituições de fomento também registro meu agradecimento. 


\section{Poroscópio}

\section{I - Porografias}

1. Exposição de uma filosofia dos poros

1.1. O sonho da integridade; 1.2. A comunicação; 1.3. Do póros marítimo à passagem socrática; 1.4. "A dialética é justamente esse percurso (poreía)". 1.5. Um discurso anacrônico; 1.6. Sarah Kofman e a tensão poro-aporia; 1.7. Sarah Kofman: Como escapar?; 1.8. Poro dialético: um caminho belo demais; 1.9. Outros discursos filosóficos sobre o poro; 1.10. Antígona: o poro trágico; 1.11. Estranha maravilha: o homem é pántopóros-áporos; 1.12. Pequena nota sobre a exposição filosófica dos poros.

2. Exposição de uma ferida dos poros

2.1. Na superfície do abismo; 2.2. Comunicaşão vem da ruptura; 2.3. Comum versus estranho; 2.4. Os céticos e a vida comum; 2.5. "Phaenomenomania"; 2.6. Nietzsche e a tragédia: cura pela máscara; 2.7. Ainda Nietzsche: $A$ sociedade raquítica dos teóricos; 2.8. Gaia ciência: comunicação a serviço da consciência; 2.9. Zaratustra: aos companheiros de viagem; 2.10. Domesticação e ideal ascético; 2.11. Heidegger: "A linguagem é a casa do ser"; 2.12. Não há domesticação sem comunicaşão.

3. Viver sem pele

3.1. Carne de vitrine; 3.2. O fantasma competente. 3.3 Günther Anders: canibalismo pós-civilizatório; 3.4. Walter Benjamin: pele, aura, labirinto; 3.5. "Sou todas as comunicações, como posso ser triste?"; 3.6. Melancolia: uma doença da imagem; 3.7. Georges Bataille: experiência interior sem interior, 3.8. Ressonâncias acéfalas; 3.9. Das Unheimliche: apreender o monstruoso; 3.10. Frend e o medo ocular, 3.11. A mulher on o terror da câmara obscura; 3.12. De passagem, uma nota.

\section{II - DANIFICAÇõES}

- Drummond: "Ao Deus Kom Unik Assão"

- À guisa de conclusão 


$$
\text { I- Porografias }
$$




\section{EXPOSIÇÃO DE UMA FILOSOFIA DOS POROS}

E esse alheamento do que na vida

é porosidade e comunicação.

Carlos Drummond de Andrade ${ }^{1}$

\section{1}

Poro é o que destrói nosso sonho de integridade. E o faz não de uma destruição a marteladas, explosiva, mas de uma destruição-diluição, líquida, pelas bordas, pela pele, pela força do impreciso. Um poro não se constrói, não se delimita, não se dobra à lei da forma. É sobretudo abertura para a existência, para o que há de comum na trajetória de cada humano, para o absurdo de sua solidão, para a remota possibilidade de comunicar a própria condição. Poro é simplesmente - ou estranhamente - a passagem para a comunicação.

\section{2}

E integridade é apenas um sonho, um velho sonho ligado a outro ainda mais antigo, o da razão - e que por isso também produz monstros. Na medida em que é um sonho da civilização, participa como força útil, como aglutinante de individualidades, como o que assegura os papéis numa sociedade obediente às exigências do tudo comunicar. A idéia de integridade alimenta a constituição de sujeitos dispostos a elaborarem o mundo e suas imagens, dispostos a tomarem parte no trabalho de emancipação pela informação. Esses sujeitos chamam a si próprios de “íntegros". E, ao contrário do que se imagina, eles não têm nada a ver com o homem inteiro, pleno de vida; são sujeitos que, justamente para provar a todo custo sua (frágil) integridade, buscam mais e mais se integrar, fazer parte, esforçam-se para ligar sua identidade a instituições, grupos, titulações. Fixam-se, habitam a cidade, vão à praça, ao mercado, lêem jornais, fazem jornais, participam do público e voltam para casa, onde - em princípio - ninguém sabe o que fazem. Trata-se de um tipo humano

${ }^{1}$ Do poema “Confidência do itabirano", em Sentimento do Mundo, 1940. 
alheio ao poroso e insensível à presença do estranho, o que equivale de certa forma à própria marca do Ocidente, luz e assombro da razão.

A partir de tal marca se formaram ao longo dos séculos os ditos conhecimentos sistemáticos, inclusive um conhecimento sistemático da comunicação. Este último, nosso objeto trabalho, toma força a partir do fim do século XIX como disciplina universitária e com ambição a estatuto científico. Desde então, muito se escreveu sobre a comunicação e seu caráter estratégico, político, mediático, simbólico, social. Pode-se mesmo dizer que a comunicação foi um dos temas privilegiados do século passado, de um século curiosamente assombrado, danificado por grandes e pequenas guerras. No entanto, isso não fez da comunicação uma ciência devidamente reconhecida. Ao contrário, certa marginalidade a acompanha: a classificação "ciência social aplicada" lhe confere posição epistemológica limitada, ou melhor, limiar. Há naturalmente quem se dedique à tarefa iluminista de levá-la ao patamar dos saberes clássicos ou das ciências ditas duras; porém tal tarefa soa aqui imprópria, no sentido em que outras possibilidades nos aparecem (erscheinen) e se mostram mais condizentes com a época e com caráter mesmo comunicacional. Assim, no contexto deste trabalho, a única medida possível é assumir a margem, fronteira, porosidade, como lugar próprio da comunicação.

Nossa tarefa é buscar aquilo que na comunicação é fenômeno marginal, produzido nos limites da história e da razão. Com isso entende-se que não serão contemplados como objeto direto de estudo os media de massa, tampouco as implicações comunicacionais do chamado espaço público moderno. Muito menos se trata de estudar a comunicação no âmbito do privado ou pessoal - isso seria tãosomente inverter os pólos da questão. O problema então obedece a uma anterioridade filosófica, tendo como fio condutor uma investigação do estatuto ontológico da comunicação, suas relações com as noções de sujeito, meio e objeto. Toma-se o comunicar sobretudo como ofício da fronteira, do conflito entre passagem e bloqueio, hospitalidade e hostilidade, entre o si e o outro. $\mathrm{Na}$ fronteira, comunicar ocupa não somente a centralidade do espaço público e citadino, mas constitui também um corpo de tensões que dificilmente teria lugar na pólis, tensões que não são nem cidadãs nem bárbaras, mas tão-somente marginais, enfim, tensões comunicantes. 


\section{3}

A entrada para essas tensões é o poro.

Porosidade, o que deixa entrar, passar, passar para mim, de mim para o outro, do outro para meu corpo; passar pela pele, pela superfície lisa para meu interior indefinido e incômodo, para esta carne que palpita, que envelhece, para estas veias, para este sangue que às vezes verte em forma de ferida. É o que no poema de Drummond mostra um homem que se esconde, que é alheio ao que é "porosidade e comunicação". Mas o que é ser alheio, se não renunciar a todas essas comunicações derrisórias, ao cotidiano que insiste em abrir passagens para o que na existência é tagarelice, discurso vazio?

Passagem marginal, no limite mesmo do ilimitado (apeíron), poro é onde dificilmente resistem os fenômenos de integridade ou, para usarmos termos da Tradição, onde toda unidade, individuação, identidade, ser, abrem-se à danificação. Por isso o poro é tão aparentado à aporia, ao impedimento da passagem, ao problema sem solução, mas também à dissolução de toda a rigidez. E mesmo operando no fronteiriço e na impotência da linguagem, deixa para nós a possibilidade ou o dever do discurso. É certo que um discurso sobre a passagem é também ele uma passagem, um atravessar pelo lógos que envolve pergunta e meditação, que envolve principalmente o movimento daquilo que passa, sua porificação. Incorporação. Neste sentido, o rastreamento de uma filosofia dos poros pode ser tentado.

Esta palavra grega, poro $(\pi \square \square \square \square)$, significa passagem. No período homérico já fazia parte do vocabulário dos navegantes, daqueles que partiam para o desconhecido, que enfrentavam os desafios do mar, onde tudo é abertura, onde não há estradas previamente traçadas: o que há no mar são tais passagens que se constituem a cada instante, póros. Esses gregos, habituados às intempéries e assombros do oceano, às monstruosidades e maravilhas, às sereias diante das quais se tem de trancar os ouvidos, ao horizonte nunca estável, a não terem chão além de um piso balaçante de navio, esses homens, quando pisavam novamente em terra firme, sentiam-se desterrados. Viam-se desalojados de sua condição navegante - até descobrirem que, mesmo em terra, não há nada que seja de fato firme. Princípio geológico da mobilidade, princípio civilizatório grego. 
Mais tarde, encontramos um segundo significado relevante para a palavra póros, predominante no período clássico: estratagema, solução extraordinária, saída pelo inteligível. Neste momento, em que a cidade é o centro do pensamento e da democracia para os gregos, póros deixa de ser apenas uma passagem marítima para assumir um estatuto teórico entre os filósofos. Mas é através de sua oposição direta, a a-poria $(\square \pi \square \square \square \square)$, que os discursos filosóficos mostram seu vigor. Aporia é ausência de poro, de passagens e de respostas; é a questão por excelência, problema sem solução, bloqueio, fronteira intransponível. Sem ela não há filosofia nem possibilidade de saída. É o pensamento levado ao seu limite. E quando se trata de limite, aporia e poro não são vistos como dualidade, mas como conceitos participantes do mesmo movimento dialético, da incessante passagem pelo pensamento e suas questões.

Não é exagerado afirmar que um pensamento da passagem, pelo menos a partir de Sócrates, tem vital importância para a filosofia. Vital, pois é assim que tomou força e popularidade a maiêutica socrática: o filósofo como parteiro das idéias. Procedimento plenamente dinâmico, realizado quase sempre em ambientes públicos como a praça do mercado ateniense, a maiêutica teve entretanto como fim primeiro dar a verdade - eterna e incorruptível - à luz. O mestre jamais se impunha dogmaticamente diante de seus adversários ou discípulos. O grande embate se dava através do diálogo, que começava geralmente com a formulação de questões aparentemente elementares como "o que é verdade", "o que é virtude", "o que é liberdade". As respostas do interlocutor eram rebatidas com mais questões, sendo estas colocadas estrategicamente com o intuito de levar à contradição e à confissão de sua ignorância. Nisso consistia a ironia socrática, em perguntas que dirigiam o diálogo não à certeza intelectual, mas à consciência de que nada se sabe. Somente assim o ensinamento do filósofo poderia fazer jus à inscrição do templo de Apolo: "Conhece a ti mesmo", ou seja, conhece que és tão-somente ser efêmero

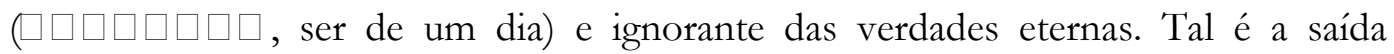
socrática para o saber, póros primordial, que dá ao pensamento vida própria, engendra reviravoltas e combate aporias. Passagem que exige esforço e perspicácia, longe da fluidez tranqüila dos rios, é antes de tudo trabalho de parto. 
Autêntico espírito de seu tempo, Sócrates foi também considerado pela posteridade como "o fenômeno formador mais poderoso da história do Ocidente."” Mesmo assim, a escassez e descontinuidade das fontes dificultam uma análise do que teria sido efetivamente sua doutrina. Como se sabe, Sócrates é tido como o filósofo que não escreveu ${ }^{3}$; bastava-lhe o vigor da voz viva e do embate dialético. Outros entretanto se incumbiram de relatar o pensamento do mestre, sendo remarcáveis neste sentido os textos de Xenófanes e de Platão. Do primeiro, sabe-se que freqüentou o mestre ateniense em sua juventude e deixou descrições sucintas. Do segundo, o mesmo não pode ser dito. Platão consagrou a Sócrates dezenas de diálogos, os quais não mostram com precisão onde termina o Sócrates histórico e onde começa o personagem porta-voz das idéias platônicas.

De qualquer maneira, tem-se na noção de dialética um importante ponto de convergência entre mestre e discípulo. Alguns comentadores dividem a obra de Platão em duas grandes fases, sendo a primeira considerada socrática. Certamente tal divisão, como qualquer periodização epistemológica e histórica, é alvo de inumeráveis controvérsias que não convêm serem aqui tratadas. Assim, guardados os limites da divisão, pode-se dizer que em seus diálogos de juventude Platão apresenta a dialética como a faculdade de apresentar um raciocínio e também de permitir que outrem o apresente. Isso está ainda muito próximo do método socrático - ou do que se conhece historicamente como tal. Uma concepção propriamente platônica da dialética só se encontra nos chamados diálogos médios e tardios, dentre os quais a “Alegoria da Caverna”, no livro sétimo da República, é exemplo paradigmático. Ali, o filósofo mostra que a aporia, prisão de sombras e ilusões, se resolve através do esforço dialético; logo, póros como passagem para a luz da verdade. A alegoria mostra o caminho do espírito, no qual tem papel fundamental a experiência visual dos prisioneiros, cujos olhos tentam virar-se para a saída da caverna e olhar primeiramente as estrelas e somente então o sol. Tenta-se gradualmente, em vez das sombras habituais, ver a verdade em toda sua luminosidade. Tal é a tentativa daquele

\footnotetext{
${ }^{2}$ A afirmação é de Werner JÄGER: Paideia - Die Formung des Griechischen Menschen. Berlin: Walter de Gruyter, 1973. Pág. 590.

3 A imagem de um Sócrates agrafo é geralmente aceita. Porém, historiadores e comentadores como Jäger e Vernant mostram que o filósofo teria sim, pelo menos, escrito poemas e contribuído na autoria de tragédias. Sarah Kofman, em sua obra Socrate(s) chega mesmo a lançar a suspeita de que Sócrates teria "ditado" vários dos diálogos atribuídos a Platão. In: KOFMAN. Socrate(s). Paris, Galilée, 1989. Pág. 13.
} 
que toma a dialética como caminho próprio do conhecimento e não deve desistir até que tenha acesso pelo pensamento ao "bem em si". E a dialética, diz o filósofo, não está nos fins, mas sim no percurso, no caminhar em direção à luz, encontro da passagem ideal.

\section{4}

"A dialética é justamente este percurso ( $\pi \square \square \square \square \square$, poreía)"4.

\section{5}

Mas tal percurso, por excelência grego, só mostra pleno vigor e sentido quando vinculado a seu próprio tempo. Assim, falar aqui de póros não é o mesmo que fazê-lo há 25 ou 26 séculos; trata-se de discurso inevitavelmente anacrônico, quando muito, diferido ${ }^{5}$, adiado. O cuidado deve começar por sua grafia, que pede variações: Póros, com inicial maiúscula, é nome próprio nas narrativas mitológicas; póros $(\pi \square \square \square \square)$, substantivo comum, designa tanto uma passagem marítima quanto a trajetória dialética; e simplesmente poro, na língua portuguesa (ou pore, escrita válida tanto em francês, inglês ou alemão) é palavra que hoje tem a ver com pele e superfície, com outros tipos de passagens e imagens. Uma investigação de suas diferenças e nuances é portanto necessária.

\section{6}

A que fontes e a que método de leitura recorrer? Há rastros possíveis teóricos ou genealógicos - quando se trata de póros, ou seja, de rotas que não deixam marcas, rotas sobre a água? A autora francesa Sarah Kofman (1934-1994) desdobrou tais questões de maneira incontornável. Interessa seguir com ela e sua obra um certo destino, ou melhor, o fatum filosófico que envolve o conceito de póros, seus vínculos com a inteligência astuciosa, com a técnica, com a maravilha-assustadora chamada ser

\footnotetext{
${ }^{4}$ PLATÃO. República, 532 C.

${ }^{5}$ Aqui se faz referência ao conceito de différance de Jacques Derrida.
} 
humano. No livro Como escapar? ${ }^{6}$ a autora solta o primeiro fio de uma intrincada rede, formada pelo pensamento daqueles que constituem não só suas referências eletivas, mas também dos que lhe são alvo simultaneamente de crítica e de interlocução. É assim que em sua rede são pouco a pouco pescadas estranhezas demasiadamente comuns. Por exemplo: um Platão capaz de forjar, não por impostura, mas em nome da passagem dialética, uma fantástica genealogia para o deus Amor; ou o impasse prometeico que faz do humano prisioneiro das vias (póros) por ele mesmo abertas. Certamente, a teia é complexa e envolve a consulta permanente da autora à sua "comunidade", formada, em primeiro plano por Friedrich Nietzsche; em seguida, por nomes como os de Jacques Derrida, Maurice Blanchot e Jean-Luc Nancy. Comunidade de homens profundamente tocados pelo terror (das Unheimliche), pela falência de comunicações clássicas como a narrativa e pela ascendência de comunicações técnicas, muitas vezes usadas para fins sinistros como a propaganda no Terceiro Reich alemão. Tem-se portanto um enredamento de vozes destinadas a narrar sem narrar; vozes que foram sufocadas mas ainda assim tematizaram as aporias de seu século para além da secularidade, pois reverberam nas bases da Civilização. Isso significa que simplesmente não há aporia que seja localizada ou individualizada. Uma aporia ecoa em todos os cantos onde houver humanidade, passa pelos poros do discurso (lógos), mas também o bloqueia com ardis, canto e poesia, em suma, com tudo o que Platão expulsou de sua República. Para seguir os rastros desse debate aporético, feito de elementos postos à margem, sugere-se aqui um trajeto porológico e porográfico que, sem ambição cronológica, começa com trabalho comum de Sarah Kofman e seus contemporâneos.

\section{7}

Como escapar? Como sair do sem-saída de uma aporia?

A saída, se existe, é de ordem do extraordinário, das forças de ultrapassamento ${ }^{8}$ como as que eram evocadas nas tragédias. Tal escape não se

\footnotetext{
${ }^{6}$ Comment s'en sortir? Paris: Galilée, 1983.

${ }^{7}$ Em verdade, trata-se da comunidade dos sem comunidade, tematizada freqüentemente nos textos de Georges Bataille e Mauriche Blanchot. O tema será retomado mais à frente.

${ }^{8} \mathrm{~A}$ tais forças os gregos chamavam $\square \square \square \square \square \square$ (deinós), palavra que denota simultaneamente o terrível e o maravilhoso. Em alemão, o termo encontra seu correlato na expressão das Unheimliche.
} 
fabrica, não se planeja; ele simplesmente aparece, torna-se visível e efetivo para, mais uma vez, se desfazer. Isso não quer dizer que tudo se opera como por milagre, sem qualquer interferência ou manobra. Eis o ponto de partida que Kofman toma para seu livro: há um tipo de inteligência negligenciada pela filosofia acadêmica, a saber, pela tradição platônica. Métis é para os gregos inteligência astuciosa, a artimanha personificada. A autora não hesita em dizer que "Platão, claramente, em nome da Verdade, teria relegado à sombra e condenado todo esse plano da inteligência, suas maneiras de compreender e suas modalidades práticas." O tema não é de todo inédito mas, de alguma forma, costuma-se "claramente" colocá-lo à sombra. A manobra de Platão ${ }^{10}$ separa métis, com seus "procedimentos oblíquos, aproximativos e incertos", da ciência dita "exata e rigorosa, a episteme filosófica" ". Manobra no entanto ambígua e plena de contornos retorcidos. Sabendo que filosofar também se firma através da contemplação, da teoria, o filósofo opera uma partilha hierarquizante, mas ainda uma partilha, "entre a filosofia e as outras ciências, a filosofia e as technê, a filosofia e a sofística"12. O imbróglio platônico coloca Métis em parentesco com Póros e Eros. Estranha, "fantástica genealogia", diz Kofman, que tem como ponto central o papel de Eros no percurso que leva ao conhecimento. Deus intermediário entre a dúvida e o saber, entre as ilusões e a verdade, os humanos e o Olimpo, Eros ou Amor é em suma filósofo. Está sempre a caminho, “emprega toda sua vida a filosofar" ${ }^{\prime 3}$. A passagem está no diálogo Banquete e desperta ainda hoje polêmica entre os comentadores.

A própria ascendência de Eros é mitologicamente nebulosa. E não há, de fato, como escreve Jean-Pierre Vernant, teogonia que seja precisa: “Que sabemos nós do nascimento dos deuses gregos? Uma pesquisa de suas origens é sempre difícil. No caso dos gregos, estamos em plena obscuridade." ${ }^{14}$ Do nascimento do deus Amor são conhecidas pelo menos três versões: no poema de Hesíodo, Eros é um princípio de união participante da origem do cosmos, juntamente com Géia e Caos; posteriormente, nas narrativas do período clássico, ele é filho da deusa do amor e da

\footnotetext{
${ }^{9}$ KOFMAN, Sarah. Comment s'em sortir. Opus cit., pág. 13.

${ }^{10}$ Detalhes sobre essa clássica questão são dados por Marcel DETIENNE e Jean-Pierre VERNANT em Les ruses de l'intelligence, la métis des Grecs. Paris: Flammarion, 1974.

${ }^{11}$ KOFMAN. Opus cit., pág. 14.

${ }^{12}$ Idem.

13 PLATÃO. Banquete, 203e.

14 VERNANT, Jean-Pierre. Mithe et societé en grèce ancienne. Paris: La découverte, 1988.
} 
beleza, Afrodite, e de Ares, deus da guerra; finalmente, no diálogo de Platão, Eros aparece como filho de Pénia, a penúria, e de Póros, o todo-passagem, o pleno em recursos.

Certamente Platão conheceu bem os mitos e a história de seu povo. Foi portanto em nome da filosofia (ou de sua filosofia) que elaborou tal genealogia. Sendo Eros filósofo, seus ancestrais equivalem às próprias forças impulsoras da inquietação pelo saber. De sua mãe, a penúria personificada, o diálogo não dá nenhum esclarecimento; é "como se, em seu infortúnio, Pénia devesse mesmo ser desprovida de qualquer ascendência, ser desde sempre órfã."15 Por outro lado, "quanto ao pai, Póros, aparece no texto como filho de Métis"", da astúcia. Kofman explica que para Platão “a ligação de parentesco entre Póros e Métis é uma ligação indissolúvel entre o trajeto, a passagem, a transposição, o recurso, a artimanha, o expediente, a techné, a luz e o limite (peiras)." ${ }^{17}$ Assim, na origem da filosofia está a inteligência plena de artimanhas e geradora de poros (porói), de estratagemas que dão escape às aporias. Tais porói não têm sequer uma existência consumada, pois estão sempre em geração, fazendo-se a cada momento em que aparece o sem-saída.

No entanto, muito ainda resta de insuspeitado entre tais relações. Para falar de Póros, Platão recorre aos mitos, mas cala sobre diversos de seus aspectos. No mais, como já dissemos, é preciso hoje lidar com o fato de que esses termos gregos, verdadeiros campos de força, caminharam no tempo. À complicada apreensão do que a palavra póros nos evoca hoje, Sarah Kofman escreve entre parênteses:

(Trata-se de dizer a dificuldade de "traduzir" póros e o termo correlativo aporia; e sublinhar as aporias nas quais mergulham os tradutores que saem de suas perplexidades ao traduzirem, em geral, póros por expediente [expédient] e aporia por obstáculo [embarras]; traduções que deixam na sombra toda a riqueza semântica de póros e de aporia, deixam impensados os laços com as palavras da mesma "família", por exemplo, com euporia, termo utilizado por Platão para qualificar o paradigma, este expediente que ele faz intervir no passo dialético para facilitar o acesso do interlocutor à compreensão de idéias

\footnotetext{
${ }^{15}$ KOFMAN. Opus cit., pág. 15.

${ }^{16} \mathrm{Idem}$.

17 Idem.
} 
inabordáveis. Elas fazem sobretudo desaparecer a ligação com o radical perao (atravessar), a relação íntima entre a mechané e o trajeto, a realização, a luz, o limite. Traduzir, abrir um caminho em uma língua utilizando seus recursos, decidir por um sentido, é sair de impasses angustiantes, aporéticos de toda tradução. É concluir o gesto filosófico por excelência, um gesto de traição. Reconhecer a intradutibilidade de póros e de aporia é indicar que, nestes termos retomados por Platão a partir de toda uma tradição, existem elementos de ruptura com uma concepção filosófica da tradução e com a lógica de identidade que ela implica. $)^{18}$

Amplitude do conceito, perigo de generalização epistemológica. Póros é a passagem, está ligado a diversas formas de estratagemas, o que no limite o remete à techné, palavra que significa técnica, mas também (e não só) arte e inventividade. Póros é abertura, indeterminação. Contudo, transformá-lo em coringa metodológico seria mais que um empobrecimento. Póros não está na ordem do método. Se Platão fala do personagem Póros em um contexto genealógico, colocando-o ao lado de Métis (a mãe), Pénia (a parceira) e Eros (o filho), é para, ao menos, mostrar que o mito não age sozinho. Póros não vem aos homens em forma de solução milagrosa; como mostra Kofman, precisa de intermediação - e esta só pode vir de Eros:

Nem mortal nem imortal, Amor é um daímon, ser intermediário. Nem sábio nem ignorante, ele é filósofo, destinado a inventar todos os tipos de astúcias; é fértil em expedientes como um feiticeiro, um mágico, um sofista. Por não possuir o saber, não deve ser confundido com Póros; ele nunca tem nenhuma riqueza. Nada guarda; deve, em cada situação, inventar caminhos inéditos, encontrar novos expedientes. Por fim, escorre sempre por entre seus dedos o proveito de suas buscas. Mas por não ser um ignorante, o filósofo Eros pode inventar, procurar. Não fica bloqueado, paralisado na aporia. Ele não está na riqueza do saber, aquela dos deuses, nem dos imortais, de Póros que, encadeados nos laços do sono e da embriaguez, não têm necessidade de buscar; tampouco está Eros na penúria, na aporia extrema, aquela que se

${ }^{18}$ Ibid., pág. 17. 
ignora como tal, na ignorância da ignorância, na certeza da opinião que nada deseja buscar pois já se crê de tudo provida. ${ }^{19}$

Como o mais humano dos deuses, Eros é quem impulsiona os mortais a saírem de suas aporias extremas, a buscarem a passagem lá onde toda passagem é obstruída. Logo, “o único póros do homem, que não é nem Póros nem Pénia-Aporia, é Eros. ${ }^{20}$ Mas não se deve esquecer que se trata de um Eros platônico, participante do percurso dialético e combatente dos falsos filósofos.

Neste combate, fica claro que nem todas as aporias são de igual valor: é preciso distinguir, no interior dos discursos, as aporias dialéticas, autênticas, das outras menores, preparadas pelos sofistas. As artimanhas sofísticas são, em Platão, criadas com o propósito de impedir a fluidez discursiva e não passam de falsas maravilhas vendidas por seus autores. Maravilhas fabricadas no sensível, jamais alcançarão a verdadeira aporia que se impõe ao filósofo que busca o inteligível, o belo e o bem eternos. A aporia sofística, em resumo, não é verdadeira e sim um artifício, recurso da techné, tramada através de uma técnica de desorientação, de maquinação que faz dar voltas". O sofista "faz o lógos voltar ao estado de caos, caos do mar ou do Tártaro, onde todas as direções são confusas" ${ }^{, 2}$. Ele pode inclusive ser comparado a Hermes, deus do comércio e do que comunica, que "para confundir as pistas, traça sobre o solo um entrelace de direções opostas" ${ }^{23}$. Fabricante de falsas questões e de discursos coloridos, retorcidos, o sofista significa uma verdadeira sombra (skia) para o filósofo:

Agilidade, polimorfismo, duplicidade, equivocidade, ambigüidade tortuosa e oblíqua, essas características do sofista são as mesmas de métis, a inteligência 'técnica' plena de recursos, de idas e voltas: aporia viva, o sofista, qualquer que seja sua situação, é sempre capaz de traçar seu próprio póros e encontrar a saída. ${ }^{24}$

\footnotetext{
19 Ibid., pág. 61.

${ }^{20}$ Ibid., pág. 62.

${ }^{21}$ Sobre as "voltas maquinadas" no discurso sofístico, ver: PLATÃO. República. 405c.

22 KOFMAN, Sarah. Opus cit., pág. 33.

${ }^{23}$ Idem.

${ }^{24}$ Ibid., pág. 36.
} 
Por outro lado, no contexto platônico a autêntica aporia é necessariamente fértil, preparadora de um caminho que se abre e se desvela. Não é para qualquer humano, claro, mas para filósofos. Porém, mesmo em sua autenticidade, observa argutamente Kofman, essa aporia tem algo de duplo, uma pré-aporia antes da aporia final. Tome-se a alegoria da caverna como exemplo: a situação inicial dos prisioneiros não é, para eles, aporética, pois suas correntes lhes são invisíveis; esses homens ignoram a situação de prisioneiros, ignoram sua própria ignorância ${ }^{25}$. "Com a cabeça imóvel, os prisioneiros não podem sequer se colocar uns diante dos outros, numa contradição fecunda que os faça terem consciência de sua ignorância."26 Somente com a descoberta de que estão em aporia é que, paradoxalmente, podem buscar uma forma de escapar - passagem da aporia ordinária, sensível, para a verdadeira. Eis o primeiro passo do percurso dialético que, de certa forma, constituise de sucessivos bloqueios em movimento ascendente (saída da caverna) e descendente (retorno). Não basta sair: o filósofo volta e reencontra os prisioneiros ainda acorrentados e sujeitos às sombras do sensível. Seu retorno é não menos difícil que a primeira viagem:

A passagem da luz à obscuridade, por sua vez, provoca os mesmos sofrimentos, mesmas perturbações, a mesma vertigem. O prisioneiro que retorna à caverna tem, desta vez, os olhos ofuscados pelas manchas vindas do sol; ele se torna inferior aos outros, pronto a rir, como se para chegar lá em cima tivesse que danificar os próprios olhos. ${ }^{27}$

Mas estes olhos, sensíveis, agora pouco importam; eles em nada contribuem para a visão do verdadeiro. Assim, a resposta à pergunta "como escapar?", embora de difícil acesso, é clara. Para Platão, a tarefa é eminentemente filosófica, constitui-se do constante a-caminho (poreín) da dialética, do encontro com a luz e do conseqüente retorno, doloroso, porém impulsionado pelo esforço de rememoração inerente à vida mortal.

\footnotetext{
25 Ibid., pág. 48

${ }^{26}$ Idem.

${ }^{27}$ Ibid., pág. 50.
} 


\section{8}

Não seria este caminho belo demais?

Com a pergunta, Sarah Kofman desconstrói o edifício platônico. Ao separar as aporias em dois tipos diferentes, "Platão camufla o caráter prometeico da empreitada filosófica." 28 Se a dialética é um belo caminho, é por estar enraizada no inteligível. Aos mortais, ela atua no campo do irrealizável e do desejo, restando-lhes buscar o saber através de astúcias e artimanhas. Ou seja, da técnica. Constatação desconfortável, pois ratifica a hipótese de que nossa sociedade moderna e tecnológica teria começado ao menos com Platão, e não com o legado cartesiano, tampouco com o período industrial e seu arrazoamento (Gestell, no vocabulário heideggeriano). Neste ponto, Kofman opõe-se abertamente a Heidegger ao alegar que este teria pensado a técnica do século XX como vinculada ao "método e aos tratados de método, a Descartes e à afirmação do sujeito como vontade." ${ }^{29}$ Deste modo, a autora adverte que em meio à pretendida pureza filosófica ocultam-se traços prometeicos, técnicos por excelência, frutos da fragilidade humana diante de seu destino aporético, finito. No caminho platônico, tal fragilidade dá lugar à busca do eterno e do Bem, num caminho "demasiado" belo, como aponta seu texto:

A via dialética, com efeito, é de origem divina. E quem a utiliza é tentado a se tornar parecido com os deuses imortais. As aporias dialéticas funcionam como punição necessária à hybris humana, uma lembrança permanente ao erro prometeico: pois foi dos deuses que veio aos homens o momento dialético que, por sua vez, não foi dado como presente: "Foi lançado do alto das regiões divinas por algum Prometeu, juntamente com o fogo iluminador." O "presente" divino foi furtado, resulta de roubo fraudulento. ${ }^{30}$

Prometeu assume um papel multifacetado. Personagem mais que complexo, é ao mesmo tempo benfeitor da humanidade e traidor dos deuses. Para salvar os mortais, rouba o fogo de Zeus - e sob o preço de seu próprio acorrentamento. Nos

\footnotetext{
${ }^{28}$ Ibid., pág. 73.

${ }^{29}$ Ibid., pág. 95.

${ }^{30}$ Ibid., pág. 82. O trecho entre aspas corresponde ao Filebo (16a e seg.), diálogo em que Platão relata o roubo do fogo divino (ali chamado de "arte dialética") por Prometeu. No Protágoras, o mito de Prometeu também aparece, mas sem o paralelo fogo/dialética.
} 
relatos Platônicos, sua figura é comparada àquela do filósofo que, do fundo da caverna, quer mostrar a luz aos mortais. Por sua inteligência extraordinária (métis), é também rival direto de Zeus. Rival ambíguo, posto que ajuda este deus quando do nascimento de Athena, filha de Métis, num parto demasiado penoso, aporético: Athena não nasce do ventre de sua mãe, mas da cabeça de seu pai, Zeus, causandolhe dores insuportáveis. "Tal função aproxima Prometeu da figura de Sócrates, parteiro de idéias" ${ }^{31}$. Nos diálogos Filebo e Protágoras, ele intervém junto aos homens no exato momento em que se procura um meio (póros) para escapar de aporias, "mais precisamente de aporias que concernem ao um e ao múltiplo, inerentes à linguagem." ${ }^{32}$ Com seus conflitos e ações ardilosas, com seus estratagemas e soluções a curto termo salvadoras, Prometeu é um permanente memento moris da Cultura. Se salva os humanos de uma morte iminente, imediata, não consegue livrá-los de sua condição inexoravelmente finita. No uso da dialética, ou melhor, do artifício dialético, abrem-se os poros que põem lado a lado finitude e eternidade. É por isso, diz Kofman, que se trata de uma bela via, mas permeada de obstáculos; oferece saídas mas deixa, no fim, nenhuma saída. O confronto com a aporia final é inevitável. A dialética, ultra-bela, pune duramente quem tenta ultrapassar seus limites ou retê-la sob um ímpeto de bybris, de excesso. Arte da temperança (sophrosyne) e da mesura, ela ensina que o caminho não é para ser possuído, mas simplesmente passado.

Sarah Kofman, contra Platão e com Platão, mostra que métis - a astúcia técnica de parentesco prometeico - é inerente ao filosofar. Assumi-la significa reconciliar o humano com sua própria condição, permitir uma "abertura final de portas às técnicas impuras, necessárias à vida." ${ }^{33}$ Como escapar? A pergunta torna-se ineficaz, porosa, na medida em que o escape é seguido de outro embaraço. E assim continuamente. A lição? "É preciso renunciar à intenção primitiva de acolher somente às ciências puras. A via mais bela é uma via mista, que não deve entretanto

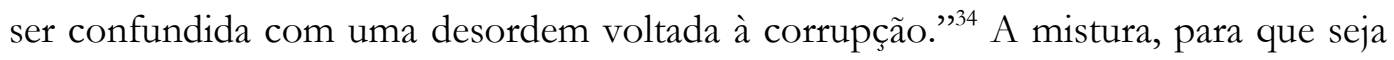
dotada de beleza, "implica medida e proporção (metron e sumetron), que destronam o prazer, colocam fim à pretensão de ocupar o primeiro lugar entre os valores." 35

${ }^{31}$ Ibid., pág. 75.

32 Ibid., pág. 81.

33 Ibid., pág. 94.

${ }^{34}$ Ibid., pág. 94.

35 Idem. 
O mito de Prometeu mostra que o homem é o único animal engendrador de póros. Só ele tem as passagens para as mais complicadas aporias; só ele sabe que técnica é sinônimo de técnica-contra-a-morte. Mas encontrar esse póros não equivale a ter um método no sentido moderno, não diz respeito ao controle instrumentalizado da natureza. Sobre essa tentadora associação, Kofman pede cautela:

Póros não deve ser confundido com ódos, termo geral que designa um caminho, uma rota qualquer. Póros é unicamente uma via marítima ou fluvial, abertura de passagem através de uma extensão caótica que se transforma em espaço discernível e ordenado, introduzindo vias diferenciadas, tornando visíveis as diversas direções do espaço, orientando uma extensão inicialmente desprovida de qualquer traçado, de qualquer ponto de referência. Póros dissipa a obscuridade reinante na noite das águas primordiais ao abrir as vias pelas quais o sol traz a luz do dia e as estrelas traçam no céu rotas luminosas das constelações. ${ }^{36}$

Com isso, vê-se que Póros jamais se desvincula do repertório mítico, mesmo se apropriado pelo discurso filosófico. Quando se diz que ele "dissipa a obscuridade das águas primordiais", um conteúdo cosmogônico lhe é conferido: Póros, personagem narrativo ou conceito dialético, participa da transformação do indiferenciado em mundo ordenado. Mas é importante lembrar que Póros não é nenhum caos, nenhum abismo primordial, e sim a trajetória que se percorre sobre o abismo para chegar ao cosmos:

Dizer que póros é um caminho a abrir sobre uma extensão líquida, é sublinhar que ele não é jamais traçado antecipadamente, sempre pronto a se apagar [effaçable], sempre a ser retraçado de maneira inédita. Fala-se de póros quando se trata de abrir uma rota lá onde não existe e não pode existir rota propriamente dita, quando se trata de atingir um inatingível, um mundo desconhecido, hostil, ilimitado, apeíron; que é impossível de atravessar de ponta a ponta; o abismo marinho, o pontos, é a aporia mesma, áporon pois

${ }^{36}$ Ibid., pág. 17-18. 
apeíron: o mar é o reino sem fim do movimento puro, o espaço mais móvel, mais mutante, mais polimorfo, onde todo caminho logo se apaga, transformando toda navegação em uma exploração sempre nova, perigosa e incerta. ${ }^{37}$

\section{9}

Sobre o poro grego e suas conseqüências na história da filosofia há ainda outros discursos, que neste trabalho não convêm serem aprofundados, mas são citados a seguir.

Antes de Sócrates e de Platão, entre aqueles que a posteridade chamou de pré-socráticos, floresceu um pensamento que entendia póros como negação da matéria - pensamento este sem parentesco com a idéia de passagem marítima nem de dialética. Trata-se da corrente atomista que, apesar de não ocupar posição central no cenário filosófico grego, ressoa ao longo dos séculos com importante participação no debate sobre o não-ser. O tema é uma rica fonte de controvérsia não só para os materialistas, mas para todas as linhas filosóficas que se ocupam da ontologia.

De acordo com o pré-socrático Leucipo, pensador do atomismo, e seu seguidor Demócrito, toda a natureza é formada de matéria (bylê) e vazio (kenós ou porói $)$. Natureza portanto porosa, plena de combinações envolvendo as diferentes formas de átomos. Nesta direção, não é possível natureza feita exclusivamente de matéria, tampouco exclusivamente de vazio. Graças aos vazios ou lacunas, os átomos, elementos simples e indivisíveis, podem se movimentar e se agregar ordenadamente, formando composições mais ou menos complexas. Assim, qualidades como cor, odor e sabor têm para esses filósofos existência apenas subjetiva ou fenomênica; as únicas propriedades reais são as propriedades geométricas dos átomos: grandeza, figura e posição.

Tal pensamento já era em seu tempo polêmico: primeiramente por se opor ao pressuposto parmenidiano de que o ser é e que, do nada, nada se pode afirmar ${ }^{38}$; em

\footnotetext{
37 Idem.

38 O poema de Parmênides diz: "Não podes conhecer o não-ser. Isso é impossível. Tampouco podes exprimi-lo. [4,7-8] É preciso dizer e pensar que o ser é, pois ele é possível, mas o não-ser não é possível. b[6,1-3]”. Sobre a natureza. A edição consultada é a de Diels \& Kranz.
} 
segundo lugar, o pensamento atomista é igualmente contrário ao mobilismo de Heráclito, já que não há um princípio único que guie a natureza como o "fogo" e sim quatro elementos que são, na verdade, variações de compostos. Também não se pode fazer vinculação com a inteligência organizadora (nô̂s) de Anaxágoras, seja ela transcendente ou imanente, pois a infinidade dos átomos em movimento já é suficiente para explicar os resultados dos fenômenos.

Para Epicuro e Lucrécio, continuadores do atomismo pré-socrático, tanto a alma quanto o corpo são formados de átomos - mas os átomos da alma são esféricos e mais leves e sutis que os do corpo. Ao morrerem, os corpos se corrompem e os átomos da alma se dispersam na grande circulação universal. Epicuro ensina: "Aqueles que pensam que alma é incorporal, pensam rasamente; pois se ela o fosse, não poderia agir nem se mover" ${ }^{39}$ Lucrécio assinala que tais átomos sutis pertencem a uma determinada região especial: "Com a velhice e com a morte, a substância da alma se dissipa como uma fumaça na altas regiões do ar." ${ }^{\text {" }}$ Isso evidencia um atomismo que não opera separação entre natureza, ética e moral.

No período medieval, o tema continua profícuo. Inspirados por Dioniso Aeropagita, Augustinho e Avicena, vários medievais representam o pensamento como uma iluminação, como relação da alma pensante com um Deus que ilumina, que esclarece através de um tipo de iconografia conceitual, adentrando os poros corporais ou espirituais. De fato, o que teria Deus de melhor representável, de mais figurável que um raio de luz, uma irradiatio, ou, numa palavra que diz simultaneamente o fenômeno e a função metafórica, onde as intuições humanas são fundamentais, uma illustratio? Não se pode esquecer que o homem medieval fabricava vitrais, que ele rezava, pensava e meditava num espaço em que a luz vibrava com cores, que a luz espiritual desenhada no espaço sagrado era também, à sua maneira, a realização de teoremas ou receitas; que Deus era ele mesmo "luz". Daí a importância nesta época dos tratados de óptica, nos quais a transparência dos corpos penetrados pela luz deve-se à porosidade intrínseca da matéria.

Tomás de Aquino, por sua vez, toma uma outra direção ao comentar o mestre antigo: "Aristóteles, nos estudos sobre os meteoros (Met. IV), afirma que os corpos são corruptíveis devido a uma certa disposição dos poros”, mas isso não se

\footnotetext{
${ }^{39}$ Em carta a Heródoto, apud Diógenes Laércio: Vida, doutrinas e sentenças dos filósofos ilustres, X, 63.

${ }^{40}$ De rerum natura, III, 455.
} 
aplica aos corpos sagrados, pois "espécies sagradas não se corrompem" No No contexto de Aquino e de seus contemporâneos, o poro era o mesmo que nada (nibi). Motivo, como sempre, de controvérsia: como pode haver o nada, se Deus está em tudo? Por outro lado, como explicar o movimento de geração e corrupção no mundo fenomênico sem a idéia de vazio? Como explicar o mal que se infiltra, que toma conta das criaturas vindas do Bem divino? É ainda de Aristóteles que vem uma saída: o vazio não é um vazio absoluto, mas tão-somente "espaço desprovido de corpo"42.

\subsection{0}

Pode-se dizer que um pensamento do poro esteve freqüentemente entre os filósofos da pólis, mas não diretamente junto a seu método ou episteme. Afinal, poro diz respeito à margem, à crise da cidade, crise de um lugar que deixa de ser palco de excelência para gerar despaisamento. Um tal pensamento só poderia participar dos campos do impreciso, do incontrolável, do movente ou então do vazio. Assim, antes de incorporar o repertório filosófico, a imagem do poro participou também dos mitos, da lírica e especialmente das tragédias, eventos dedicados ao que no humano é abismo, desmesura, incompreensão, exaltação. As palavras pantopóros áporos (pleno de póros mas em aporia), proferidas pelo coro dos anciãos de Tebas em Antígona, revelam aos humanos o terrífico de sua condição. Palavras continuamente reinterpretadas e reassimiladas pela cultura, guardam em si o vigor das questões inesgotáveis. Por isso a Antígona de Sófocles merece aqui nossa atenção.

Esta tragédia está entre as mais célebres de todos os tempos. Não por menos, a gama de interpretações e debates que suscita é tão ampla quanto complexa. Diferentes conflitos aparecem na trama: família versus cidade, indivíduo e comunidade, feminino e masculino, tradição e novos valores, poder dos deuses e governo humano. Tais pontos, de maneira intermitente, são privilegiados por interpretações específicas da história. Em países como Rússia e Alemanha, na primeira metade do Século XX, prevaleceu a imagem de uma Antígona que sintetizava a dialética entre indivíduo e Estado. Na Europa após a Segunda Grande Guerra, a tragédia recebeu inúmeras adaptações, feitas por nomes como o de Bertold Brecht.

\footnotetext{
${ }^{41}$ AQUINO. Suma teológica. III, 77, $2^{\text {a }}$ objeção.

${ }^{42}$ ARISTÓTELES. Física. IV, 214b24-214b28.
} 
Foi neste período que se disseminou o lugar comum de que Antígona seria a heroína suicida por excelência, representando a perda de força vital do indivíduo frente a um sistema político injusto e autoritário. A fala "se antes da hora morrermos, consideroo ganho" ${ }^{43}$ tornou-se uma espécie de mote ${ }^{44}$ entre os românticos alemães e também entre estudantes do pós-guerra. Mas, para além desta interpretação melancólica, a tragédia escrita por Sófocles é exemplar em muitos outros sentidos. De Hegel, apesar de sua pouca modéstia, podemos ouvir o seguinte elogio: "De tudo o que há de grandioso no mundo antigo e moderno - eu conheço praticamente tudo, e é preciso conhecer tudo, o que também é possível - me parece, segundo este lado, que Antígona é a obra de arte mais excelente, a mais satisfatória." 45

Como personagem, a moça não encarna o típico herói, dotado de força física e apoiado pela comunidade. É mulher e enfrenta, minoritariamente, o tirano e toda a cidade. Antígona faz parte de uma linhagem de antemão desdita: filha de Édipo e Jocasta, é fruto (juntamente com seus irmãos Ismene, Etéocles e Polinices) de uma aliança caracterizada pela desmesura, cópula assombrosa. $\mathrm{O}$ destino malogrado não lhe surpreende, como ela própria declara no início do texto da tragédia: "Comum no sangue, querida irmã, caríssima Ismene, sabes de algum mal, dos que nos vêm de Édipo, que Zeus não queira consumar em nossas vidas?" ${ }^{46}$ Noção de destino própria dos personagens sofocleanos, que confrontam situações extremas e mostram capacidade fora do normal, mesmo sobre-humana, para enfrentar os golpes do tempo e as reviravoltas da existência. ${ }^{47}$ Neste sentido, de acordo com comentadores contemporâneos, são insuficientes as análises hegelianas comandadas pela dialética entre o público e o privado. Antígona opõe-se ao governante de Tebas, Creonte, para louvar a honra de sua família. Louvor motivado pelo sangue derramado de seu irmão Etéocles: morto por ter lutado contra sua pátria, o jovem teve o corpo abandonado às aves de rapina, pois as honras funerárias foram-lhe recusadas pelo Tirano.

\footnotetext{
${ }^{43}$ SÓFOCLES. Antígona, 461. Tradução brasileira de Donaldo Schüler. Porto Alegre: L\&PM, 1999.

${ }^{44}$ Comentário feito por Dietmar Kamper, em conferência proferida em São Paulo e publicada como: O trabalho como vida. São Paulo: Annablume, 1998.

${ }^{45}$ HEGEL, Georg W. F. Cursos de estética. Vol. IV. Trad. Marco Aurélio Werle \& Oliver Tolle. São Paulo: Edusp, 2004. Pág. 256.

46 Antígona. 1-5. Todos os trechos citados são da tradução de Donaldo Schüler, feita diretamente do grego para a língua portuguesa.

47 A afirmação encontra-se no comentário de Newton Bignotto. O tirano e a cidade. São Paulo: Discurso, 1998. Pág. 56.
} 
Seguindo um estudo de Newton Bignotto, é preciso atentar mais uma vez para as anacronias, inevitáveis quando se trata das relações entre o mundo clássico e o nosso. $\mathrm{O}$ autor lembra, em primeiro lugar, que a família não tinha para os gregos o mesmo significado que para as sociedades modernas: "Os laços que unem Antígona a seus irmãos não implicam somente o afeto entre os descendentes de uma mesma mãe, mas a participação em uma mesma história, no caso, em um mesmo destino, cuja marca não pode ser apagada pela afirmação de uma individualidade excepcional." ${ }^{48}$ Bignotto ainda salienta que:

Antígona é descendente dos Labdácidas, participa de uma trajetória marcada por vários acontecimentos fora do comum. Sua oposição não pode ser vista como a de uma garota piedosa que decide, contra o Estado opressor, respeitar as obrigações de uma boa irmã. Mas, sobretudo, a oposição entre a cidade e a família não pode ser reduzida à de dois direitos opostos. O que observamos, e que certamente não passou despercebido para o espectador da época, é que o conflito entre genos e pólis, que se iniciara com Sólon, que percebeu a importância de redimensionar o lugar do genos na cidade, para remodelar a vida institucional, e que aparece com toda força no teatro de Ésquilo, ainda tem um peso importante na cidade democrática do século $\mathrm{V}$ a.C. ${ }^{49}$

Tal visão corrobora, de certa forma, a tese do alemão Karl Reinhardt. Para este, o conflito acontece, em realidade, entre a tradição (mito) e a nova pólis (razão) ${ }^{50}$. Antígona é representante da tradição e dos deuses; é ela a responsável em sua família pelo culto ao Zeus doméstico. Por isso a heroína não teme a morte. Mais vale agradar aos deuses e a seus mortos do que ao governo de um efêmero. No prólogo dialogado com Ismene, ela se faz irredutível: "Por mais tempo deverei agradar os lá de baixo que os cá de cima; lá repousarei para sempre." ${ }^{51}$ Se Antígona é porta-voz das tradições, deuses e mitos de sua terra, Creonte, representa por sua vez o vínculo

\footnotetext{
${ }^{48}$ BIGNOTTOO. Opus cit., pág. 57.

${ }^{49} \mathrm{Idem}$.

${ }^{50}$ REINHARDT, Karl. Sophokles. Frankfurt am Main: Vittorio Klotermann, 1976.

51 Antigona, 75.
} 
inevitável do humano com a técnica. Destino prometeico, ligado à inteligência astuciosa de Métis, como já vimos com Sarah Kofman. Combater o tirano significa, no limite, combater a natureza humana.

Mas neste contexto, de acordo ainda com Bignotto, a própria noção de natureza do homem deve ser questionada. Tal seria, em princípio, a principal função do coro dos anciãos de Tebas, opinião (doxa) fundada na justa medida, proclamada após a desmedida demonstração de poder do tirano. Nesse coro, Sófocles faz um elogio às maravilhas e aos assombros humanos, que se reúnem numa única expressão grega: deinós. Palavra intraduzível em sua integridade, ainda é tema de calorosos debates tanto entre tradutores quanto entre filósofos. Pode-se dizer que, nos textos épicos, deinós significa habilidade técnica, perspicácia típica humana para criar estratagemas, saídas excepcionais. Mais tarde, no tempo de Sófocles, o termo diz respeito ao próprio extraordinário, às forças que o humano é capaz de imprimir sobre a natureza, forças essas vindas de sua própria natureza. Por isso deinós estaria ligado a póros, como mostrará engenhosamente o texto grego.

O homem é uma maravilha-assombrosa (deinós), dentre todas a maior. Encontra saídas para o sem-saída e se perde nas tramas por ele mesmo tramadas. É o animal pantopóros áporos, pleno de póros mas sempre em aporia, sempre embaraçado. Tem na cidade o seu lugar excelente, sua casa, mas continua se sentindo despaisado, sem pátria por onde quer que ande. Onde está sua pátria, qual é o chão capaz de acolhê-lo em plenitude? E para onde foge ao desenvolver tantas artes e habilidades? De onde foge? - Da morte, diz Sófocles. E para ela, por maiores que sejam as maravilhas dos humanos, estes seres de um dia, não há ainda escape. Aporia entre as aporias, a finitude é fonte de inventividade para homens medianos como Creonte. Não para Antígona, pois esta não teme morrer, ao contrário, deseja ardentemente o dia de sua entrada heróica no Hades, onde poderá juntar-se aos seus: "Não padecerei, com certeza, nada que não seja morrer gloriosamente. ${ }^{, 52}$ Com isso fica claro que a atitude da heroína não tem a ver com nenhuma disposição suicida, como fora interpretada pelo romantismo alemão e mais tarde pela crítica da segunda metade do século XX.

${ }^{52}$ Ibid., 95. 


\subsection{1}

Para apreender os meandros do coro, embora sem as sutilezas do original, segue a tradução do "Hino aos assombros/maravilhas do homem" "53:

"De tantas maravilhas,

mais maravilhoso de todas é o homem.

$\square \square \square \square \square \square \square \square \square \square \pi \square \square \square \square]$

O espumante mar nos ímpetos dos ventos austrais

sulca, bramantes ondas fende,

e cultiva a dos deuses mãe, a Terra

imortal, incansável, revolvendo-a ano após ano

com arados movidos por força eqüina.

A linhagem das leves aves leva capturadas

e as raças das feras agrestes,

peixes em pencas prende nas malhas das redes

o homem perspicaz;

engenhoso persegue a fera fauna dos montes,

doma corcéis, ao duro jugo sujeita touros sanhudos.

A voz, o pensar volátil

e as urbanas leis das assembléias

ele as ensinou a si mesmo,

fugiu da áspera agressão do frio

e dos dardos das tempestades.

Aparelhado, desaparelhado

$\square \pi$

não acata nada do que lhe advém;

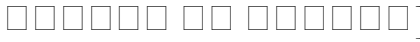

só da morte fuga não lhe acena,

\section{$[\pi$}

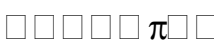

[335]

[340]

[350]

[355]

[360]

$[\pi \square \square \square \square \pi \square \square \square \square$

$\square \pi \square \square \square \square \square \square$

53 Antígona, 332-375, trad. Donaldo Schüler. A numeração à direita do texto corresponde à contagem de linhas do original grego. 
ainda que de indômitas moléstias

alcance escape. 
De saber fecundo, move recursos inesperados

ora ao bem, ora ao mal.

Una as leis da Terra à justiça jurada dos deuses,

e amuralhado será;

[370]

$\square \pi$

desamuralhado

se saiba, porém, atrevendo-se a insultá-las.

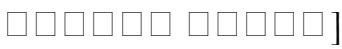

De meus altares não se aproxime

nem perturbe meu pensar quem assim procede.'

[375]

De início, a voz dos anciãos de Tebas é discurso reativo aos atos de bybris do tirano. Porém representa mais que isso, já que parte da observação da vida política para retratar os conflitos do destino humano em toda sua amplitude. Nas peças de Sófocles, os coros tinham papel importante na crítica à nova configuração da cidade, esta marcada pela decadência da democracia. Um estudo de Kathrin Rosenfield mostra, neste ponto em concordância com Hegel, que o coro é a "forma mais pura e abstrata do espírito agonístico da pólis clássica" ${ }^{, 54}$, que ele aponta principalmente para a "natureza desamparada do homem, /.../para a qual o entendimento procura em vão o limite e em relação à qual ele jamais encontra uma posição exterior e objetiva." ${ }^{55} \mathrm{O}$ trabalho de Rosenfield contribui no sentido de elucidar as dificuldades do texto grego sob a ótica da tradução consagrada de Hölderlin. Este poeta teria dado ao coro um tom mais intenso do que no original, cujo objetivo seria trazer à tona ao leitor moderno o espírito do texto trágico. Por este motivo, as comparações entre Tebas e as sociedades européias posteriores são mais que mera anacronia, são um instrumento de aproximação entre duas épocas distintas. Rosenfield argumenta:

Nas Observações sobre Édipo, Hölderlin compara o ambiente desta Tebas devastada à atmosfera da Europa dos tribunais da inquisição (Ketzergericht), quando desordens múltiplas - religiosas, econômicas e políticas provocaram uma instabilidade generalizada, material e espiritual. Um nada

\footnotetext{
${ }^{54}$ ROSENFIELD, Kathrin H. Antígona - de Sófocles a Hölderlin. Porto Alegre: L\&PM, 2000. Pág. 122.

${ }^{55}$ Idem.
} 
pode acender, em tais situações, os espíritos exaustos pelo sofrimento e perseguidos pelos "fantasmas proféticos" (Wahrsagergeist) que espreitam em toda parte bodes expiatórios. $\mathrm{O}$ anacronismo deliberado desta comparação adverte o leitor ingênuo de que a pólis grega está sujeita às mesmas oscilações e vicissitudes que podem rejeitar civilizações desenvolvidas (como a medieval e a moderna) nas trevas e em percepções arcaicas.

O ponto central do canto desloca-se ora para os ardis de Creonte, ora para os princípios civilizadores, estes sim, conflitos perenes: "são a inquietude e a curiosidade diante das conquistas formidáveis sobre as quais se funda a cultura, a esperança de ordem e de civilização, mas também o avesso inquietante desta procura e destas conquistas - a apreensão de que elas não passam de uma simples transgressão, de um crime. ${ }^{, 56}$ Nenhuma palavra expressa melhor tais dilemas da civilização do que deinós, habilidade, ardil, força de ultrapassamento. Hölderlin a traduziu pelo adjetivo ungeheuer, que quer dizer monstruoso. Para Kathrin Rosenfield, a escolha "intensifica o sentido mais convencional do grego deinós. ${ }^{, 57}$ Num primeiro momento, o poeta alemão teria utilizado gewaltig (imenso, poderoso), mas trocou mais tarde por ungeheuer, "substituição essa que, provavelmente, corresponde a ponderações relativas ao sentido global da tragédia." 58 Tal é sua proposição para os dois primeiros versos: "Há muitos assombros, mas nada tão assombroso quanto o homem.",59

Assombroso ou monstruoso é aquele que ensina a si mesmo a arte da palavra e, em seu próprio proveito, domina a natureza. A linhagem das leves aves, para Hölderlin são "pássaros sonhadores" capturados e dominados. Essas aves, assim como as demais presas de caça, são vitais para a instauração da cultura, das marcas humanas deixadas diariamente sobre o planeta. E na cultura alguns homens assumem o papel de caçadores, enquanto outros se aparentam aos animais caçados. Antígona seria uma espécie de pássaro emaranhado: "Numa certa perspectiva, tudo se passa na cidade de Tebas como se Creonte tivesse traduzido o ardil da arte da caça num audacioso modo de governar - seu élan/orgulho de governar a cidade exige que ele

\footnotetext{
56 Ibid., pág. 124.

57 Ibid., pág. 125.

58 Idem.

${ }^{59}$ Tradução de K. Rosenfield para a versão hölderliana do coro.
} 
capture o 'pássaro sonhador' Antígona nas suas malhas." ${ }^{\text {60 }}$ A monstruosidade do tirano não lhe é algo estrangeiro; está em sua constituição ser caçador ou predador.

Na mesma trilha de Hölderlin está Martin Heidegger, que encontra para deinós um equivalente no termo alemão unheimlich. O caminho realizado pelo filósofo até chegar a esta tradução aparece primeiramente em "O significado grego do homem na Antígona de Sófocles" ${ }^{\prime \prime}$, texto este que se reproduz uma década mais tarde com alterações na obra Introdução à metafísica ${ }^{62}$. No sentido corrente, o substantivo de gênero neutro das Unheimliche significa estranho, terrível, extraordinário. No entanto, a composição da palavra evoca detalhes relevantes ${ }^{63}$ : o radical é Heim, a casa, o lar, que dá origem por exemplo a Heimat (pátria) e ao adjetivo beimisch (familiar, caseiro); heim-lich, por sua vez, é o adjetivo para secreto, oculto; por fim, o prefixo un-funciona como partícula privativa, de forma que un-beim-lich diz respeito ao incomum, ao nãofamiliar ou a algo que deveria permanecer secreto mas vem à tona. Atento à complexidade do termo, Heidegger propõe a seguinte tradução para os dois primeiros versos do coro dos anciãos em Antígona:

\section{Vielfälltig das Unheimliche, nichts doch}

Über den Menschen hinaus Unheimlicheres ragend sich regt.

(Muitas são as coisas estranhas, nada porém

Há de mais estranho do que o homem." ${ }^{\text {64 }}$ )

Portanto, deinón não é mais o "monstruoso" de Hölderlin; deinón é agora o "estranho", conceito ligado tanto à "terra" quanto ao seu revés: terrí-vel, des-terro, terror. O que está em questão, adverte Heidegger, não são pequenos temores, tampouco um uso corriqueiro da palavra terrível (das Furchtbare): "Deinón é o terrível no sentido do vigor predominante, que provoca, simultaneamente e de modo igual, tanto o terror do pânico, a verdadeira angústia, como o temor concentrado, quieto,

\footnotetext{
${ }^{60}$ Ibid., pág. 130.

${ }^{61}$ HEIDEGGER, Martin. "Die griechische Deutung des Menschen in Sophokles' Antigone”, (1942). In: Gesamtausgabe. Frankfurt am Main: Vittorio Klotermann, 1984.

62 . Einführung in die Metaphysik (1953). Tübingen: Max Niemeyer, 1987. Os trechos citados são da tradução brasileira de Emmanuel Carneiro Leão: Introdução à metafísica. Rio de Janeiro: Tempo Brasileiro, 1978.

${ }^{63}$ Heidegger não é o único a tratar do tema. Freud e, posteriormente, Jacques Derrida, Sarah Kofman e Vilém Flusser deixam suas contribuições. A questão será retomada à frente.

${ }^{64}$ HEIDEGGER, Martin. Introdução à metafísica. Opus cit., pág. 170.
} 
que vibra em si mesmo." ${ }^{, 5}$ Trata-se do terrífico em seu mais pleno vigor e violência (Gewalt), quando toda familiaridade se converte em estranhamento, assombração. Se Heidegger prefere utilizar a palavra unheimlich a ungeheuer, é porque a monstruosidade inerente ao humano não vem de fora, mas constitui seu destino naquilo que lhe é mais próprio. Aqui é preciso pôr em evidência dois temas privilegiados pelo filósofo no período da Introdução à metafísica: o vigor e a morada. Ambos estão ligados à técnica, mais precisamente aos modos de interferência e produção (bervorbringen) dirigidos à natureza. Poiesis e techné são as formas que o homem tem de produzir e de produzir-se, de trazer à aparência o que estivera oculto; elas são, em resumo, da ordem do desvelamento (Atletheia).

Graças a esse vigor poiético, o ser-lançado-no-mundo pode ali fazer morada, construir e sentir-se em casa. Deste modo, o lar e a pátria não devem ser considerados como prerrogativas humanas inquestionáveis: é preciso edificá-los, num trabalho de contínuo diálogo da existência (Dasein) com o seu meio (Umwelt) ${ }^{66}$. Como todo diálogo, implica estranheza e alteridade, sobretudo do homem com relação a si mesmo:

Por "estranho" [das Un-heimliche] entendemos como o que sai e se retira do “familiar", isto é, daquilo que nos é caseiro, íntimo, habitual, não ameaçado. O estranho não nos deixa estar em casa. Nisso reside o vigor que se impõe e subjuga. O homem é o que há de mais estranho, não só porque conduz o seu ser no meio do estranho, assim entendido, mas por afastar-se e sair dos limites, que constituem, em primeiro lugar e às mais das vezes, a sua paisagem caseira e habitual; por transpor, como o que instaura vigor, as raias do familiar e se aventurar justamente na direção do estranho no sentido do vigor que se impõe.

/.../ A afirmação "O homem é o que há de mais estranho" dá a definição propriamente grega do homem. Só atingiremos completamente o acontecer dessa estranheza na medida em que também fizermos experiência do poder

65 Ibid., pág. 172.

${ }^{66}$ Estes temas são típicos do período posterior a Ser e tempo, que alguns comentadores chamam de "o segundo Heidegger". São tratados com detalhes em textos como "A questão da técnica" e "Construir, habitar, pensar”, publicados em 1954 na obra Ensaios e conferências (Vorträge und Ausätze). Ver: HeIDEGGER, Gesamtausgabe. Frankfurt am Main: Vittorio Klotermann, 1984. 
da aparência e do combate com ela, como pertencente à essencialização da existência. ${ }^{67}$

Em seguida, Heidegger mostra a ligação entre deinón e póros. A interpretação é complexa, visto que Sófocles joga habilmente com a linguagem, como se vê nos versos “Pantopóros áporos ep'ouden erchetai” (linha 360 e seguintes). O brasileiro Donaldo Schüler traduziu-os como "Aparelhado, desaparelhado / não acata [o homem] nada do que lhe advém; / só da morte fuga não lhe acena." Para Heidegger, no entanto, os poros dizem respeito a caminhos desbravados, o que remete de certa forma às clareiras ou aos caminhos nas florestas (Holz̧wege). Sua proposição para esses versos é a seguinte: "Pondo-se a caminho por toda parte, desprovido de experiência e em aporia, chega ele ao Nada.” Pede-se atenção principalmente para este trecho do coro, pois coloca em questão todo o ardil e estranheza humanos, assim como os limites da empreitada prometeica. Heidegger comenta:

A palavra póros significa: travessia por, passagem para, caminho. Por toda parte, o homem se abre caminhos. Atreve-se em todos os setores do ente, do vigor imperante que se impõe. E por isso se vê lançado fora de todo caminho. Somente deste modo se abre toda a estranheza daquele que é o que há de mais estranho. Não apenas por experimentar em toda a sua estranheza o ente em sua totalidade. Não só porque nela rompe, como aquele que instaura o vigor, o que lhe é familiar. Ele se torna em tudo isso o que há de mais estranho porque, estando em todos os caminhos em aporia, sem saída alguma, se acha expulso de qualquer referência. Toda a ligação com o familiar lhe é cortada. A atè, a ruína ou a desgraça, vem sobre ele. Pressentimos agora em que medida esse pantopóros áporos contém uma interpretação do deinótaton. ${ }^{68}$

\footnotetext{
${ }^{67}$ HEIDEGGER. Introdução à metafísica. Opus cit., pág. 174. No original: „Das Un-heimliche verstehen wir als jenes, das aus dem „Heimlichen“, d.h. Heimischen, Gewohnten, Geläufigen, Ungefährdeten herauswirft. Das Unheimische lässt uns nicht einheimisch sein. Darin liegt das Über-wältigende. Der Mensch aber ist das Unheimlichste, weil er nicht nur inmitten des so verstandenen Un-heimlichen sein Wesen verbringt, sondern weil er aus seinen zunächst und zumeist gewohnten, heimischen Grenzen heraustritt, ausrückt, weil er der Gewält-tätige die Grenze des Heimischen überschreitet, und zwar gerade in der Richtung auf das Unheimliche im Sinne des Überwältigenden.“

${ }^{68} \mathrm{Idem}$.
} 
É como pressentimento ou suspeita (Ahnung) que o filósofo apresenta a relação entre os dois trechos expressos no coro. A cautela não é gratuita, pois indica um distanciamento proposital com relação às argumentações apodíticas, demonstrativas. Traduzir não é demonstrar, principalmente no contexto heideggeriano; trata-se antes de interpretar a tradição e trazê-la para o próprio conjunto conceitual que, neste caso, culmina na idéia de desvelamento. Tal caminho Heidegger cumpre a passos lentos, levando os termos póros e deinón, passagem e ardil, à luz da vida na cidade. Já se sabe que aos humanos é inerente habitar. Mas não de qualquer modo: a cidade é seu lugar excelente, a melhor amostra de sua habilidade produtiva, inteligência e poder, assim como de seus conflitos. Por isso, a leitura do coro não se conclui até que se considere o verso 370: bypsípolis apolis, "amuralhado desamuralhado" ou "todo-urbano inurbano". A estrutura é mesma de pantopóros áporos, mas se refere, segundo Heidegger, a uma outra dimensão da existência:

Não se evoca mais o póros mas a pólis. Não se indicam todos os caminhos do domínio do ente, mas o fundamento e o lugar da existência humana. O ponto de convergência e cruzamento de todos os caminhos é a pólis. Traduz-se pólis por Estado ou Cidade-Estado. Essa tradução não atinge o sentido pleno da palavra. Pólis quer dizer a localidade, a dimensão $[D a]$ em que como tal a existência [Dasein] expande seu acontecer histórico. A pólis é o lugar histórico, o espaço no qual, a partir do qual e para o qual acontece a história. A essa dimensão histórica pertencem os deuses, os sacerdotes, as festas, os jogos, os poetas, os pensadores, os governantes, o conselho dos anciãos, a assembléia do povo, o exército dos guerreiros, os navios. ${ }^{69}$

No entanto, há aqueles mortais que, justamente por integrarem a cidade e por nela desempenharem ações relevantes, sentem-se deslocados ou despaisados (unheimlich). Esses homens, como presume Heidegger, são simultaneamente cidadãos e á-polis, "sem cidade e sem lugar, solitários, estranhos, aporéticos (sem saída) no meio do ente em sua totalidade, sem constituição e limites, sem estrutura e dispositivos, de vez que, como criadores, são eles que devem então fundar e instaurar

${ }^{69}$ Ibid., pág. 175. 
tudo isso." ${ }^{, 70}$ Poetas, pensadores, sacerdotes seriam os representantes por excelência desse ethos. Sua aporia não diz respeito a dificuldades externas, pois com relação a estas podem sempre seguir adiante. $\mathrm{O}$ verdadeiramente aporético para um mortal consiste "no fato de ele sempre ser reconduzido aos caminhos por ele mesmo abertos, aferrando-se a seus percursos, enredando-se no já percorrido, traçando nessa rede o círculo de seu mundo, emaranhando-se com a aparência e trancando-se assim no Ser." ${ }^{, 71}$ Eis o que faz o homem o que há de mais estranho (deinós) entre todas as estranhezas, mas também o mais maravilhoso entre todas as maravilhas.

Heidegger, ao revisitar Hölderlin, diz que o "homem habita como poeta sobre a terra." Ou seja, habita desde que consolide com plenitude sua aptidão poiética, criadora, transformadora, técnica e, por que não, prometeica. Isso não contradiz a afirmação de Aristóteles de que o homem é feito para a pólis, para a atividade política, para a contínua construção de uma vida na cultura. Costuma-se dizer que, aquele que ultrapassa os limites da cidade, tende a aparentar-se ou às bestas ou aos deuses. Mas tais limites são demasiado tênues e, quanto maior a cidade, maior a sensação de desterro.

Com Antígona aprendemos que uma cidade não é apenas uma: a Tebas das tradições e do culto aos deuses não dialoga com a outra, do tirano e das novas leis. Diferentes tempos coexistem através de seus cidadãos, mas não harmonicamente; entre tais tempos não costuma haver comunicação, mas tão-somente re-mediações, terapias de ordem política. "Pleno de póros e em constante a-poria": a definição sofocleana para o humano faz de Antígona, ainda hoje, texto fértil e inspirador.

\subsection{2}

Pequena nota sobre esta "exposição de uma filosofia dos poros": Primeiramente, não se tratou de expor no sentido dos tratados filosóficos, com os detalhes e aprofundamento inerentes a esses textos. Aqui, exposição é tão-somente um aparecer, um momento em que o pensamento se apresenta segundo uma ordem que, como já dito no início, não é cronológica e sim porológica, determinada por disposições, passagens, portais que levam do pensamento de Sarah Kofman a Platão,

\footnotetext{
${ }^{70}$ Idem.

${ }^{71}$ Idem.
} 
e deste a Sófocles. Em segundo lugar, toda exposição expõe apenas parcialmente, deixando um hemisfério eclipsado. Trabalha-se então no reconhecimento dos limites, da impossibilidade de aceder qualquer concepção total. A própria idéia de póros está ligada aos limites e fronteiras, inclusive do corpo, da pele. Assim o poro, ao contrário do methodos moderno, não tem a ver com a dissecação do morto, mas com a percepção do vivo. Tal é o motivo de sua inevitável aposta no impreciso, ou melhor, no que se move e participa do cosmos.

Pode-se dizer que poro é a substância da margem. Mas principalmente que poro não é substância nenhuma. É certo que remete à nostalgia da unidade, não de uma unidade ontológica, mas daquela que aparece na figura platônica da caverna, assim como nos arquétipos femininos, ligados à passagem uterina. O debate é inesgotável e perpassado por diferentes discursos. Abertura assombrosa, brecha escancarada, abismo, ferida, são imagens que se condensam no poro e também em seu avesso, a aporia. Mas é preciso dizer que o poro não é nenhum caos, nenhuma fenda primordial, pois se manifesta superficialmente, ao dar passagem, na fronteira entre obscuridade e luz. A investigação da superfície é que nos leva ao próximo capítulo. Como observou o Nietzsche do Nascimento da tragédia, no superficial suavizam-se o terror e a agonia do trágico, encobre-se o abismo da existência. Neste sentido, toma-se a comunicação como o que acontece no limite da alteridade evento pleno de estratagemas, ardis, mas também surpresas, fatum. Passagem como tantas outras, inscrita em cada um de nós desde o momento em que nascemos. Poro enfim como na palavra de Carlos Drummond de Andrade:

\footnotetext{
"Eu corria ao vento, era só umidade, era só passagem e gosto de sal." 72
}

72 "Rola mundo", in A rosa do povo, 1945. 


\section{EXPOSIÇÃO DE UMA FERIDA DOS POROS}

O mandamento da vida explode em riso e ferida.

Drummond $^{73}$

\section{1}

Se o abismo não tem fundo, tem superfície. E esta é finamente marcada por cisões, fissuras, linhas, fronteiras, porosidade. Superfície da máscara trágica, da pele, dos espelhos e das telas mágicas. Superfície inevitável da comunicação (Khôra? ${ }^{74}$ ), lugar do social, das exposições à luminosidade, da razão e da consciência, mas também lugar dos efeitos, das imagens e dos fantasmas. Seu reconhecimento está na indecidibilidade, no não-identitário: ela, a superfície, não existe "em si" e nada tem de topografia ou de lógica dos planos cartesianos. Tampouco é horizontal, plana ${ }^{75}$, mensurável, dominável. É somente um campo de contato, necessária dimensão do comum - a preparar no humano o espanto do incomum, do estrangeiro. Por vocação, a superfície se disfarça. Talvez seja como a natureza (physis) de Heráclito, que ama se esconder ${ }^{76}$. E por isso é difícil que seja efetivamente vista, sentida, vivenciada. O que se vê geralmente é um falseamento da superfície, sua perversão.

\section{2}

A palavra grega para comum é koinós, que nem sempre significou ordinariedade, mas partilha de uma mesma condição. Vida comum, vida em comum, bios koinós. Apropriado pelos latinos, o conceito condensou valores da Antigüidade

\footnotetext{
73 "Favelário nacional". In: Corpo, 1984.

${ }^{74}$ Khôra $(\square \square \square \square)$ é a palavra grega para espaço ou lugar, mas não no sentido topográfico. Jacques Derrida investiga o termo no Timeu de Platão: “A Khôra não é nem sensível nem inteligível, ela pertence a um terceiro gênero. /.../ Aparece como estranha à ordem do paradigma, deste modelo inteligível e imutável.” In: Khôra. Paris: Galilée, 1993. Pág. 16.

75 Relembremos Nietzsche quando fala do feminino: "Considera-se a mulher como profunda. Por quê? Porque nela não se toca jamais o fundo. A mulher não é sequer plana." In: Crepuisculo dos idolos, "Máximas e sentenças", \27.

${ }^{76}$ Fragmento 123 de Heráclito de Héfeso: "A natureza ama esconder-se".
} 
tardia. De communis, aparecem a comunhão, a comunidade, os gestos de comungar, comer, comemorar. São lugares comuns, originalmente, destinados para atividades de agregação. Mas como cada conceito traz em si a potência da perversão ${ }^{77}$, o comum também se transmuda em vulgaridade, abaixamento, e igualmente em co-sofrimento (mit-leiden), ou seja, compaixão. Com base nesses princípios praticamente teológicos, os humanos se põem cada vez mais em contato, participam, transitam mutuamente. O aumento das possibilidades comunicativas (linguagens e técnicas) é geralmente proporcional à miséria de seus atores. Quanto mais vulneráveis a intempéries, pestes, bestas ou guerras, mais estratagemas e meios encontrarão os humanos para se unirem uns aos outros e garantirem a sobrevivência da espécie. Sobrevivente será, portanto, não o indivíduo forte, mas a maioria feita de humanos médios, comuns.

Se a comunicação não foi tema privilegiado pelos gregos, para os modernos é questão crucial. A gama de debates não tem mais como se restringir a demandas comunitárias. Daí o investimento no repertório categórico, que elevou a comunicação ao patamar científico. Trata-se, principalmente a partir do século da Luzes, de transmitir informação como o mais puro objectum; de estabelecer ligação entre sujeitos que representam na Terra o uno, o indivisível, o incorruptível; de esclarecer a maioria através de influências civilizadoras (para não dizer domesticadoras); de fragmentar a linguagem em signos a fim de torná-la transparente, manipulável; de fomentar o espírito científico, jornalístico, para sempre se chegar mais fundo nos fatos - até a perversão de chamar o superficial de vulgar. A partir daí, pode-se lançar a seguinte tese: o que se conhece como a moderna ciência da comunicação é fruto de uma série de perversões. Entenda-se por perversão a metamorfose do conceito em monstruosidade, criação de um híbrido (nascido de bybris, bem entendido) e sua subseqüente instalação na alta hierarquia dos ditos valores civilizatórios.

O conceito de comunicação, para o sociólogo alemão Dirk Baecker ${ }^{78}$, oscila entre a pergunta se a comunicação é de fato possível e a de que tudo é comunicação.

\footnotetext{
77 Sobre verdade e mentira no sentido extramoral (1873) é o texto em que Nietzsche denuncia o "conceito como resíduo da metáfora", "moeda que perdeu a efígie", sem valor nem vigor, mas tomado quase sempre como verdadeiro. Atenção ao seguinte trecho: "Toda palavra torna-se logo conceito quando justamente não deve servir, eventualmente como recordação, para a vivência primitiva, completamente individualizada e única, à qual deve seu surgimento, mas ao mesmo tempo tem de convir a um sem número de casos, mais ou menos semelhantes. Todo conceito nasce por igualação do não-igual. /.../ A desconsideração do individual e efetivo [Wirklichkeit] nos dá o conceito, assim como nos dá também a forma, enquanto a natureza não conhece formas nem conceitos."

${ }^{78}$ BAECKER, Dirk. Kommunikation. Leipzig: Reclam, 2005. Pág. 30.
} 
Resta ainda saber se ela é alguma coisa. Mesmo com os instrumentos do método a seu serviço, as observações dos processos comunicativos nunca são conclusivas. Investiga-se um processo cujos elementos dispersam-se entre supostos códigos lingüísticos, corporais e temporais que nada têm de comum. Ora, o comum é uma grande fábula que se distancia cada vez mais de si mesma, distorcendo-se, fantasiando-se, fazendo-se em fantasma. Seqüestra seus senhores, como adverte o ensaio de Pál Pelbart:

Perambulamos em meio a espectros do comum: a mídia, a encenação política, os consensos econômicos consagrados, mas igualmente as recaídas étnicas ou religiosas, a invocação civilizatória calcada no pânico, a militarização da existência para defender a "vida" supostamente "comum", que quando compartilhamos esses consensos, essas guerras, esses pânicos, esses circos políticos, esses modos caducos de agremiação, ou mesmo essa linguagem que fala em nosso nome, somos vítimas de um seqüestro. ${ }^{79}$

No limite, os avessos se encontram. O comum volta a ser incomum. O comunicável, de tão usado ou pervertido, vira incomunicável. Seqüestrados, seduzidos por promessas de retorno a uma vida em comum, significativa, os sujeitos se tornam impotentes - e passam a sujeitar-se aos próprios fantasmas. Para Baecker, "os meios de comunicação se aproveitam da incomunicabilidade dos indivíduos." Norval Baitello Jr. vai mais longe ao afirmar que "quanto mais ressaltamos e nos orgulhamos dos bons serviços e das qualidades da comunicação, mais a incomunicação ganha força e ousadia" e o faz "provocando estragos, desfazendo e desmontando, semeando discórdia e gerando falsas expectativas, invertendo sinais e valores, azedando as relações e produzindo estranhamentos incômodos." ${ }^{81}$ Para este autor, incomunicação é o nome que se dá aos fantasmas dos vínculos rompidos. ${ }^{82}$

79 PÁL PELBART, Peter. “A comunidade dos sem comunidade”. In Vida capital: ensaios de biopolítica. São Paulo: Iluminuras, 2003. Pág. 28.

80 BAECKER. Ibid., pág. 39.

${ }^{81}$ BAITELLO, Norval (org.). Os meios da incomunicação. São Paulo: Annablume, 2005. Pág. 9.

82 Ibid. Pág. 11. 


\section{3}

Se o homem é o animal comunicante, não estaria compelido a investigar, no interior de sua natureza, as razões pelas quais ele opta por romper o isolamento e tornar(se) comum? Então, a caminho de tal questionamento, não verá ele que o comunicar é antes a exposição da ferida, da incompletude, da angústia? A necessidade do comum surgiria assim da ruptura. Principalmente o isolamento, a nostalgia do contínuo ou qualquer outro nome que se queira dar a esse impulso metafísico, convocaria os humanos à comunicação. Tal perspectiva, de uma comunicação como efeito marginal e poroso, está presente sobretudo em filosofias não sistemáticas do século XX. Na con-vocação e no com-parecimento de suas necessidades, os humanos se põem em comum. No entanto, esse gesto não tem nada de comum pois resulta de um desterro, de um constante mal-estar com a própria condição. Estranhamento do outro no mesmo que, num bom exemplo, a reflexão de Olgária Matos aproxima do flâneur:

É dessa natureza o estranhamento do forasteiro benjaminiano, em meio a uma cidade desconhecida: nunca relativo ao outro, mais ao próprio viajante, afastao de si mesmo, revelando a frágil familiaridade de si mesmo. /.../ Não abarcamos o "estrangeiro" fora de nós, só o tocamos dentro, pagando o preço de nossa própria transformação. A relação com o outro é o que exige distanciamento e, primeiramente, de nós mesmos para que dele tenhamos a experiência. $^{83}$

Essa alteridade, tão bem captada por Walter Benjamin, não tem parentesco com o princípio de exclusão cartesiano. Ou seja, o flâneur não é o sujeito em busca de um mundo maquinizado, mas sim alguém que cultiva sombras e paisagens inteiras, dando novamente ao espaço a tridimensionalidade que lhe é própria. Mais ainda, o flâneur afirma na experiência (Erfahrung) sua temporalidade, reencontra a mágica. Opera em direção contrária às Luzes (Aufklärung) que, por excesso de iluminação, conceberam um mundo em plano único, sem a sensação de profundidade ocasionada pelo claro-escuro. Com este personagem aprendemos a pôr em dúvida as teorias do

${ }^{83}$ MATOS, Olgária. História viajante: notações filosóficas. São Paulo: Studio Nobel, 1997. Pág. 144. 
"lugar-natural" de filiação aristotélica, pois a cidade - ou a pólis em crepúsculo transformou-se em labirinto aberto ao nomadismo. A experiência de se perder mostra enfim que o lugar do homem são muitos: comum, em-comum, incomum.

\section{4}

Os filósofos gregos céticos tinham uma interessante teoria sobre o comum. Para eles, a única coisa comum a todos é o fenômeno - o que torna a comunicação inevitável, necessária para a manutenção social. Eles se opunham às filosofias dogmáticas, buscando no pensamento uma espécie de terapia contra as aporias.

"Vejo-me diante de minha escrivaninha, pondo no papel minhas reflexões. Meu cachorro, José Ricardo, está deitado a meus pés. Ouço o ruído distante dos automóveis na avenida Marginal." ${ }^{\prime 4}$ Esta confissão, que poderia facilmente ser incorporada à crônica de qualquer anônimo habitante das grandes cidades, ocupa antes páginas dedicadas ao lógos. Oswaldo Porchat no século XX, através dos pirrônicos antigos, ensina isso: que o filósofo cético é também um homem comum, a usar suas chinelas e andar pela praça do mercado como qualquer outro; que, após suspender renovadamente seu juízo, nada de muito extraordinário toma lugar no cotidiano. Continua a se sentir como antes, a cheirar, enfim, a viver segundo o que aparece. Fica contudo a tranqüilidade - reservada aos que rejeitam as convicções fáceis e as soluções mágicas oferecidas pela via dogmática.

O mesmo lógos do qual fazem uso os filósofos acadêmicos e dogmáticos é o que dá vigor ao combate exercido pelos céticos. Estranho instrumento de luta. Incansáveis praticantes da aporia, os céticos pirrônicos vêem teses cair por terra colocando argumentos lado a lado, mostrando as fraquezas dos vários discursos e, no limite, sua equivalência. Neste campo não há verdade possível, apenas perturbação dos sentidos e da razão, na inquirição de problemas que, se não podem ser resolvidos, podem pelo menos sofrer o escrutínio da atividade discursiva. Fora isso, então, que resta ao filósofo se não seguir o comum? Ora, qual o problema em sentar num bar e beber com os amigos, também filósofos provavelmente, cada qual ciumento de sua bibliografia cuidadosamente apreendida ao longo dos anos de

${ }^{84}$ PORCHAT Pereira, Oswaldo. "Sobre o que aparece”. In: Ceticismo e vida comum. Pág. 176. 
trabalho intelectual. Mas no bar, lá, podem de forma menos dogmática conversar sobre futebol (se bem que este tema muitas vezes esbarra na fronteira do indecidível) ou sobre mulheres. $\mathrm{O}$ fato é que, filosofias à parte, estamos todos expostos e sujeitos ao fenômeno, ele é a única coisa que não podemos negar, pois nos aparece sem pedir permissão. Toma a cena e só nos resta segui-lo. E o fenômeno é justamente aquilo sobre o qual não cabe discussão. Está no domínio do particular e intransferível. Por isso o professor Porchat, no mesmo texto em que fala de seu cão José Ricardo (não pode falar de outros cães, nem de outros donos, mas apenas daquele cão que lhe aparece como seu), fala também de filósofos sentados em bares ou, ainda, lembra o episódio em que um certo pensador austríaco diz: "Ninguém duvida que eu use cuecas sob as calças". ${ }^{85}$

Mas deixemos de falar de cuecas ou de cães, isso seria tema para os cínicos ${ }^{86}$. Sexto Empírico, filósofo do século II d.C., ao concluir as Hipotiposes pirronianas, aponta o cético como um philanthropos, um amigo da humanidade que, por este motivo, deseja curar a e a precipitação dos dogmáticos por meio da argumentação ${ }^{87}$. É certo então que o dogmatismo é mal a ser sanado, mas antes de falar de sua terapêutica é adequado apresentar o cético e os possíveis motivos de sua filantropia.

Inicialmente, o cético é aquele que se diferencia voluntariamente dos seguidores das filosofias dominantes. Não fala através de afirmações ou demonstrações, mas a partir do fenômeno. Sexto empírico, ao apresentar as “diferenças dominantes entre os filósofos", no livro I das Hipotiposes, salienta: "De nada do que será aqui dito poderemos assegurar que seja completamente como dizemos, mas sim para cada coisa que façamos historicamente um relato conforme ao que nos aparece no momento." 88 Sua atividade é chamada de: "inquiridora (zetética), pois concerne à pesquisa e ao exame cuidadosos; efética ou suspensiva (épokhè) devido à afecção (pathos) advinda da investigação; e aporética, pois como dizem alguns, a respeito de tudo cai em aporias e não sai do caminho da busca" ${ }^{\text {" }}$.

85 Idem, pág. 182: “Porque se trata dos 'fenômenos comuns' que a todos se impõem irrecusavelmente e que a filosofia jamais cogitou recusar (nenhum filósofo idealista jamais negou que Wittgenstein usasse cuecas sob as calças)."

86 "Cínico" em grego significa cão e é o nome de corrente filosófica contemporânea ao ceticismo.

${ }^{87}$ SEXTUS EMPIRICUS. Esquisses pirrhoniennes [Hipotiposes pirronianas]. Trad. Pierre Pellegrin. Paris: Seuil, 1997. Em III, 280, segundo a numeração original.

88 SEXTUS EMPIRICUS. Opus cit. I, 4.

${ }^{89}$ Ibid., I, 7. 
Esta filosofia é também chamada de pirrônica, pois remete a Pirro, que viveu aproximadamente entre 360 e 270 a.C., contemporâneo de Aristóteles e de quem pouco se tem registros mas que, segundo Sexto Empírico, aproximou-se de maneira mais consistente e destacada quanto ao ceticismo do que seus antecessores. Portanto, o filósofo pirrônico é alguém que indaga incessantemente, sem se preocupar em encontrar uma verdade final. Não por menos, a leitura moderna (em nomes como os de Hume, Kant e Rousseau) viu pejorativamente nos céticos gregos tipos excêntricos, nômades, ofensivos e mesmo indolentes.

O filósofo pirrônico tenta simplesmente viver sem emitir opiniões (é adoxátos), longe da via do juízo. E seu horizonte de ação não é mais a cidade ou pólis. Vale lembrar aqui que o período em que se desenvolveu o ceticismo corresponde a um certo declínio da pólis, às invasões e ao enfraquecimento de uma democracia outrora plena. Mesmo as filosofias contemporâneas ao pirronismo (estoicismo e epicurismo, por exemplo), embora ditas dogmáticas pelos céticos, direcionaram suas investigações para a natureza e para uma ética mais individual do que política. No caso do ceticismo, a atitude suspensiva vem como remédio à perturbação tanto dos sentidos como da alma, sendo sua filosofia uma conduta (agogé) possível, uma disposição para a oposição e não uma teoria.

Não há doutrina cética. Mas há o filósofo cético, mistura de investigador, anti-dogmático, argumentador. Ele conhece o lógos e suas artimanhas, porém unicamente para testar os limites do discurso e para mostrar, passo a passo, que os argumentos todos se equivalem, não restando salvação. Pobre de quem for crédulo. Talvez esteja aí a filantropia do cético: ele deseja que outros vivam como ele na via do que aparece, segundo o fenômeno, na vida comum (bios koinós). Seu télos contudo é a ataraxia: tranqüilidade adquirida somente após a suspensão do assentimento, após a verificação de que a questão é indecidível. E sempre aparecerão novas questões. E sempre ele se inquietará e novamente se acalmará.

Os homens estariam assim unidos não mais por doutrinas enganadoras, mas pelo fenômeno e pela vida comum. A palavra koinós abrange assim tanto o ordinário, corriqueiro, quanto o comunicável, partilhável. O cético, embora denuncie que o fenômeno aparece para cada um e que cada um pode falar unicamente do que aparece para si, não faz apologia do isolamento. Há uma comunicação possível, enlaçada pelas fronteiras do questionamento e do aparecer, e da qual ele se apraz em 
participar. Há também, seguindo estes mesmos critérios, ações possíveis: o cético, justamente por suspender o juízo sobre as questões dogmáticas, não é um ser imóvel. Integra-se tanto quanto necessário à cidade, cuida de sua sobrevivência, freqüenta a praça do mercado, brinca com seu cachorro.

Mas não se deve esquecer a cura. Há na filosofia pirrônica forte identificação com a prática terapêutica. Como já se disse, o télos cético é a saída do estado de perturbação causado pela diafonia, pela pluralidade de eventos do mundo e, mais ainda, pela pluralidade de interpretações sobre esses mesmos eventos. O fim desta desordem interna, sem bem que momentâneo, é a ataraxia, calma digna do filósofo. Como filantropo, então, este filósofo difunde aos outros homens seu modo de vida, não por achar-se melhor dotado (isto seria um contra-senso), mas simplesmente por conhecer a cura para a doença reputada por ele como das piores. E não só os filósofos são atingidos pelo mal dogmático, mas também cidadãos ditos comuns.

Sexto Empírico era médico. Em seus esboços sobre o pirronismo há mais de uma passagem evocando uma terapêutica pelo lógos, a qual envolve também a boa medida na prescrição. Por exemplo: “Assim como os médicos têm para as afecções corporais remédios em diferentes graus e importância, e prescrevem pois fármacos severos àqueles tomados por severos males, e fármacos leves para os que são tomados por males leves, o cético, da mesma forma, endereça argumentos de diferentes intensidades. ${ }^{.90}$ No trecho seguinte, Sexto apresenta o procedimento mais adequado para com os dogmáticos: "Ele [o cético] recorre a argumentos pesados e capazes de destruir vigorosamente esta afecção dos dogmáticos que é a presunção, sobretudo aqueles que são tomados por forte precipitação; mas o cético emprega também argumentos mais leves para os que são tomados de uma presunção superficial e de fácil cura, podendo ser destruída por persuasões mais leves." ${ }^{\text {11 }}$

É claro que a exposição dessa terapêutica não é tão simples. Na tradição pirrônica, são fundamentais os modos de suspensão de Enesidemo e Agripa, que apresentam detalhadamente formas argumentativas de combater o ceticismo ou pelas aporias ou pela diafonia, ou ainda pela descrição das sensações, com exemplos de como aquilo que aparece é particular e portanto impassível de juízo definitivo.

\footnotetext{
${ }^{90}$ Ibid., I, 280.

${ }^{91}$ Ibid., I, 281.
} 
Questiona-se mesmo o nível de afinidade entre as vias da medicina corporal e da argumentativa. No fim do primeiro livro das Hipotiposes temos: "Com efeito, da mesma maneira que o cético serve-se, sem emitir opinião, das expressões 'não determino nada' e 'não alcanço nada', como já foi dito, o médico [metodista] também fala de 'comunidade' ou de 'invasão' e outros termos semelhantes sem buscá-los tão longe. De forma semelhante, eles utilizam o termo 'indicação' sem sustentar opiniões, pois é guiado pelos afetos (páthos)." O trecho é finalizado da seguinte maneira: "Há portanto uma afinidade entre a via metódica e o ceticismo, mais do que entre outros casos de escolas médicas, sendo que isso ocorre sobretudo por comparação com estas últimas (e não de forma absoluta): é preciso conjeturar a partir do que precede e das coisas semelhantes."

Sim, o cético deseja curar aqueles que tomam parte na vida comum, sejam filósofos ou cidadãos anônimos. O remédio - ou argumento - varia de acordo com o grau da doença e com o tipo de paciente. Um homem comum, quando dogmático, vê-se enraizado em crenças as quais ele sequer conhece a origem, sua certeza é fundada na ignorância. O filósofo, por sua vez, sabe de onde vêm suas convicções mas é ainda incapaz de se dar conta do calabouço onde se encontra. Mas não é por vontade ou arbitrariedade que o cético se põe tal tarefa; é o que nos explica o professor Oswaldo Porchat, falando contudo não somente do filósofo pirrônico mas também de si mesmo:

É importante ressaltar que essa nossa postura cética de agora, não a devemos a nenhuma decisão filosófica. Nada estabelecemos nem demonstramos, nossa investigação filosófica não tem nenhum salto positivo a oferecer. Nossa epokbé é tão-somente o estado em que nos encontramos, quando uma investigação exaustiva empreendida com rigor e espírito crítico nos deixa precisamente sem condição para escolher ou decidir. Por isso mesmo, ao invés de dizer que praticamos uma épokhé, é mais adequado dizer que entramos em épokhé, ou que estamos em epokhe. ${ }^{92}$

92 PORCHAT. Opus cit., pág. 170. 
Ainda citando Porchat, podemos ressaltar que o pirronismo não constitui negação absoluta nem do real nem da razão. Trata-se antes de investigação bem demarcada sobre os limites do pensar, mostrando sempre os prejuízos e ilusões a que se incorre quando se embrenha na busca cega de uma verdade apofântica:

Sem jamais incorrer em qualquer negativismo epistemológico, o pirronismo não se faz nunca uma teoria, insistindo em definir-se tão-somente como uma prática filosófica, de valor eminentemente terapêutico. Confiando diálogo e na argumentação e deles fazendo seus instrumentos, ele pretende por seu intermediário contribuir para o bem-estar e o progresso espiritual dos homens. Cabe também dizer que, pela própria natureza de seu método e procedimento, o pirronismo se constitui como um antídoto eficaz contra toda e qualquer forma de irracionalismo. Ao rejeitar os dogmatismos, ele conforma uma outra e diferente figura de racionalidade. ${ }^{93}$

Com isso, o cético também se faz consciente do quão limitado é seu projeto de cura ao dogmatismo. Sempre haverá novos doentes e novos desafios. Portanto, atividade ininterrupta, conduta diária e para toda a vida. Seu propósito inclui um desencantamento dos pacientes: tira-se a magia - ou o glamour, para usar uma palavra moderna - que envolve o saber. Filosofar agora é investigação arguta e quase sempre aporética, abertura de sendas hostis no interior da linguagem e do pensamento, é opor os argumentos fazendo-os equivalerem-se até a morte. Mas é também a cura das certezas enfeitadas e sedutoras. E para este filósofo a melhor recompensa é a vida comum, o humor inquebrantável e a serenidade - como a companhia do cachorro numa tarde ou, quem sabe ainda, preocupar-se com o fato de ninguém se preocupar com as cuecas de Wittgenstein.

\section{5}

"Phaenomenomania." 94

${ }^{94}$ NIETZSCHE. Fragmentos póstumos. VIII - 6 [19], primavera de 1887. 


\section{6}

Nietzsche nos adverte contra o fenômeno, sugerindo que ele pode ser comum demais, na direção mesma de uma mania. No entanto - de modo oposto à filosofia cética e a outros pensamentos posteriores de ordem fenomenológica - o tema da terapia e da convalescença também lhe aparecem reiteradamente.

Um fragmento póstumo, datado de 1886, diz: "Maske und Mittheilung". Sem entrar ainda na sutileza filológica, a tradução "Máscara e comunicação" é aceitável. O tema da máscara acompanhou Nietzsche desde os tempos de $O$ nascimento da tragédia até seus últimos escritos: um espírito profundo, ele dizia, ama a superfície, ama a máscara. Tal é o movimento, ora tenso ora harmônico, entre Dioniso e Apolo: o primeiro como exaltação da obscuridade e do incontrolável e, o segundo, como a beleza necessária para encobrir o que não pode ser visto. A máscara - ou o apolíneo é possibilidade para aqueles que ousam a experiência verdadeira e profunda. Máscara é então pressuposto para a comunicação do incomum, do efetivo (Wirklichkeit); é o que torna a vida leve e remedia (re-medium) a tensão trágica. Ela é por excelência o medium do homem trágico. Assim, o apolíneo não existe por si, não é mera frivolidade, mas a superfície através da qual é possível contemplar visualmente o abismo da existência.

O pequeno texto "Maske und Mittheilung" toma forma de enigma. Cuja resolução, que fique bem claro, não sairá jamais do âmbito da especulação. $\mathrm{Na}$ ortografia alemã do século XIX, escrevia-se Mittheilung e não Mitteilung ${ }^{95}$. Com isso, a hipótese seguinte não é de todo descabida: o autor privilegia a partícula Heil que, em alemão, significa cura. A construção é análoga à que se faz nos termos latinos medium e remedium. Assim, comunicar - como sugere o enigma nietzschiano - implicaria um adoecer e um curar-se, um pathos e uma convalescença conjuntos. No Nascimento da tragédia, o tema é trabalhado e notado em certos jogos de palavras:

${ }^{95}$ Em alemão existem duas palavras para comunicação: Kommunikation, de origem latina e Mitteilung, germânica, sendo que esta última diz respeito mais à transmissão do que à troca entre interlocutores. E meio, medium, em alemão se diz Mittel. O tradutor Rubens Rodrigues Torres Filho, do volume Nietzsche da edição Os pensadores, anota que a relação etimológica entre Mittel e Mitteilung é falsa. Nietzsche a usa em vários trechos apenas como recurso retórico de assonância. Diz o tradutor na página 346 das Obras incompletas de Nietzsche: "Mittel significa meio; Mitteilung, por sua vez, é a junção de mit (com) e teilen (dividir, partilhar)". De mesma natureza - ou estratégia nietzschiana - é a aproximação Theilen e Heilen, sendo que o $b$ neste caso também não garante nenhum parentesco etimológico, mas é colocado de maneira a provocar uma assonância, uma ambigüidade. Esta letra, que mais tarde foi abolida da ortografia alemã, era comum na escrita de várias palavras como: Thier (animal), theilhaften (participar) e Urtheil (juízo). 
Quando numa tentativa enérgica de fitar de frente o sol, nos desviamos ofuscados, surgem diante dos olhos, como uma espécie de remédio [Heilmittel, manchas escuras: inversamente as luminosas aparições dos heróis de Sófocles, em suma, o apolíneo da máscara, são produtos necessários de um olhar no que há de mais íntimo e horroroso na natureza, como que manchas luminosas para curar [Heilen] a vista ferida pela noite medonha. ${ }^{96}$

A partilha ou comunicação, no caso da existência trágica, é um evento de superfície - porém digno dos homens profundos, uma espécie de ilusão curativa. Dáse pela articulação entre dionisíaco e apolíneo, profundidade e superfície, indiferenciação e individuação. Não se trata de dualidade, mas antes de complementaridade. A obra trágica surge de Dioniso e Apolo, afirma Nietzsche, "da mesma forma que a procriação depende dos dois sexos, em que a luta é incessante e onde intervêm periódicas reconciliações." ${ }^{97}$ E o que ela comunica está além de todas as outras comunicações, pois pressupõe vínculos e experiências afirmativos. $\mathrm{Na}$ tragédia, os indivíduos envolvidos não fogem à morte nem criam laços comunicativos para escapar à finitude; ao contrário, seguem destemidamente em direção ao fim e nisso consiste seu traço heróico.

Nietzsche, ao trabalhar sobre uma pluralidade de tipos e perspectivas, sugere para cada exemplar humano sua forma própria de comunicar. Os efeitos terapêuticos da ação trágica não seriam assim para qualquer um. Dirigem-se àqueles que, por disposição fisiológica, rejeitam qualquer espírito de rebanho, qualquer remédio compassivo. O comunicar trágico (Mit-theilen) seria assim a arma de combate contra a compaixão (Mit-leiden ${ }^{98}$ ), ou seja, contra os vínculos que se dão pelo sofrimento. Num fragmento póstumo do período 1888-1889, fica clara sua posição afirmativa quanto à tragédia. Ali, Nietzsche vê já em Aristóteles um representante da moral compassiva e por isso se opõe à Poética do mestre grego:

\footnotetext{
96 O nascimento da tragédia, $1872, \int 9$.

${ }^{97}$ Ibid., $₫ 1$.

${ }^{98} \mathrm{O}$ termo Mitleiden, normalmente traduzido por compaixão, tem formação análoga ao Mittheilen do fragmento citado acima. É composto por mit (com) e leiden (sofrer).
} 
Aristóteles queria que a tragédia fosse encarada como purgativo da compaixão [Mitleiden] e do terror, - como uma útil descarga de dois afetos doentios acumulados de modo excessivo...

Os outros afetos atuariam tonicamente: mas apenas dois afetos depressivos e esses são, portanto, especialmente prejudiciais e malsãos -, a compaixão [Mitleiden] e o terror [Schrecken] deveriam ser como que por meio de um purgante eliminados para fora do ser humano: a tragédia, na medida em que desperta em excesso esses dados perigosos, livra deles o ser humano - tornao melhor. A tragédia como cura contra a compaixão. ${ }^{99}$

No Nascimento da tragédia, obra que vários críticos distanciam da produção posterior nietzschiana, já se encontram com clareza os elementos dessa guerra contra os compassivos. Se há no humano uma necessidade de metafísica, esta deve ser suprida pela arte e não por pensamentos ou religiões reativos, diz o filósofo. $\mathrm{Na}$ tragédia, quando dionisíaca, "o efeito mais imediato é que o Estado e a sociedade, sobretudo o abismo entre um homem e outro, dão lugar a um superpotente sentimento de unidade que reconduz ao coração da natureza." ${ }^{100}$ Tal é o consolo metafísico buscado por Nietzsche, pois garante através da música do coro e da ação que "a vida, no fundo das coisas, apesar de toda a mudança das aparências fenomenais, é indestrutivelmente poderosa e cheia de alegria." ${ }^{\prime 101}$

Mas o tempo em que os homens podiam experimentar os efeitos da cura trágica durou pouco. A tragédia, segundo nos conta o filósofo, morreu heroicamente. Diante dos novos conflitos da cidade, da expulsão dos poetas da pólis e do desenvolvimento de um novo tipo de civilização - a dita civilização Alexandrina, cujo tipo representante é o crítico, mescla de bibliotecário com revisor ${ }^{102}$ - o coro trágico recolheu-se no silêncio. E teria sucumbido diferentemente de todas as outras artes: "morreu por suicídio, em conseqüência de um conflito insolúvel, portanto tragicamente, ao passo que todas as outras expiaram em idade avançada, com a mais bela e tranqüila morte."103

\footnotetext{
${ }^{99}$ NIETZSCHE. Fragmentos póstumos, 1888-89. VIII, 10 (15).

100 O nascimento da tragédia. $\$ 7$.

101 Idem.

102 Ibid., \ 18.

103 Ibid., $\ 11$.
} 


\section{7}

Extinta assim a cultura trágica, o que resta é uma sociedade raquítica, azeda, "levedada até as suas camadas mais baixas." 104 O palco mítico dá lugar a personagens que vivem da especulação dirigida à natureza e à moral. Agora entra em cena um outro tipo humano, chamado por Nietzsche de o teórico: "equipado com as mais altas forças cognitivas, trabalha a serviço da ciência, cujo tronco ancestral é Sócrates. ${ }^{~}{ }^{105} \mathrm{E}$ tal cenário se estende até o período moderno, para o qual não só as possibilidades trágicas estão perdidas, mas também a força educativa. O mundo ficou sem Paidéia, órfão. Num primeiro momento desta orfandade, a tarefa da continuidade civilizatória teria sido tomada pelas universidades e, mais tarde, pela imprensa. Tipos como o crítico, o professor universitário e o jornalista, seriam portanto sintomas irreversíveis de decadência:

/.../ Se a autêntica força educativa das instituições superiores de ensino nunca foi, a bem dizer, mais baixa e débil do que no presente, se o “jornalista”, o escravo do papel do dia, levou de vencida, em tudo o que se refere à cultura, ao professor de ensino superior, a este último não resta senão a metamorfose, tantas vezes já experimentada, de agora se movimentar também conforme o estilo do jornalista. ${ }^{106}$

Com isso, a perspectiva tragi-heróica dá lugar a outras formas de comunicação, ou melhor, sintomas da cultura. A vista do abismo não causa mais horror a ninguém, simplesmente porque ninguém mais o contempla. Nietzsche tratará agora de novos males e novos meios de saná-los. Ao longo de toda sua obra, várias perspectivas se entrelaçam: o comunicar está ligado à origem da consciência, servindo apenas ao corte mediano, uma ponte pragmática entre humanos; contribui para o enfraquecimento dos indivíduos, na medida em que estes usam da comunicação para tornar suas existências mais distendidas, isto é, como um instrumento da facilidade, do espírito de rebanho, das religiões; também está a serviço da "pequena política", da democracia representativa; alimenta o

\footnotetext{
104 Ibid., \ 18.

105 Idem.

106 Ibid., \20.
} 
sedentarismo, a acomodação do indivíduo num solo único, encurtando seus horizontes; segue direção oposta à corporeidade e à afirmação dos impulsos de vida; mas restaria talvez uma última possibilidade comunicativa: aquela que acontece entre companheiros de viagem, entre humanos dispostos a partilhar suas experiências, mesmo que sabendo que estas são intransferíveis. De qualquer modo, Nietzsche vê a comunicação moderna não mais como remedium, mas como narcótico - uma anestesia que tira do ser humano o poder de experimentar, sentir o mundo.

\section{8}

Um dos principais lugares comuns sobre a comunicação está ligado à alteridade. É preciso haver um outro, algo que gere uma certa noção do próximo e seus limites. Somente então se estabelece uma relação, vínculo de amizade ou hostilidade. Mas para Nietzsche a base moderna dessa relação é propriamente uma ilusão, perversão conceitual, fantasmagoria cujo ponto de partida é o cogito, um sujeito que é tanto especular como especulativo:

Que compreendemos de nosso próximo, senão suas fronteiras, quero dizer, aquilo com que ele se inscreve e se imprime sobre nós? Nada compreendemos dele, senão as mudanças em nós que são por ele causadas nosso conhecimento dele semelha um espaço oco a que se deu uma forma. Nós lhes atribuímos as sensações que os seus atos despertam em nós, dandolhe, assim, uma falsa positividade inversa. Nós o construímos segundo o que sabemos de nós, dele fazendo um satélite de nosso próprio sistema: e, quando ele nos ilumina ou se escurece, e somos a causa última de ambas as coisas - nós acreditamos o contrário! Mundo de fantasmas este em que vivemos! Mundo invertido, virado, vazio e, no entanto, sonhado cheio e reto! ${ }^{107}$

Outros impulsos (Triebe) operariam de maneira semelhante. A empatia, por exemplo, está igualmente ligada à idéia de proximidade e alteridade. Mas com uma diferença: é alimentada pelo medo. Querer compreender o outro, afirma Nietzsche,

107 Aurora (1881). \ 118. 
vem de uma temeridade primordial, da necessidade de conhecer as intenções ameaçadoras do estranho: "Se nos perguntarmos de que modo a reprodução dos sentimentos de outros tornou-se tão comum para nós, não há dúvida quanto a resposta: o homem, sendo a mais temerosa das criaturas, devido à sua natureza frágil e refinada, tem no seu temor o mestre dessa empatia [Mit-empfindung], dessa rápida compreensão pelo sentimento do outro (também do animal)." ${ }^{108}$ Assim a comunicação empática, ao contrário do que se pensa, não se dá entre pares mas entre relações de forças bastante desiguais. Trata-se ainda de sentimentos fundados em compaixão, boa vontade e piedade, em resumo, em valores metafísico-cristãos: "um processo místico mediante o qual a compaixão (Mitleid) reúne dois seres em um, tornando possível a um a imediata (unmittelbar) compreensão do outro.”109

E para tudo isso - alma, compaixão, empatia - deve haver lugar no corpo, pois apenas o corpo é capaz de gerar, mediar e organizar tais tensões. Nietzsche sugere mesmo um órgão responsável pela comunicação no homem: a consciência. E ambos, comunicação e consciência, não teriam surgido do nada, mas a partir de um lento processo de coações, temeridade e necessidade de sobreviver. Somente com esta finalidade o humano teria aprendido o senso comunitário, para buscar no outro um aliado contra perigos e barbáries. Logo, para Nietzsche, o homem não é naturalmente gregário ou político. Primeiramente, porque não há “o” homem, o que há no máximo são tipos humanos e, dentre estes, a maioria é possivelmente formada por indivíduos de tendência gregária. Esta maioria, numa espécie de evolucionismo perverso (em que os mais fracos predominam), teria se desenvolvido a tal ponto em que toma conta do planeta não só quantitativamente, mas também cultural e politicamente. Consciência, pois, é habilidade (métis) dos fracos que só sobrevivem se estiverem unidos uns aos outros. Esta concepção de humanidade está presente em várias obras do filósofo alemão, sobretudo no período de $A$ gaia ciência. No trecho seguinte, que acompanharemos com interrupções, Nietzsche alinhava com destreza a subordinação da consciência à necessidade de comunicação.

O problema da consciência (ou, mais precisamente, do tornar-se consciente) só nos aparece quando começamos a entender em que medida poderíamos

\footnotetext{
108 Ibid. $\int 142$

${ }^{109}$ Idem.
} 
passar sem ela: e agora a fisiologia e o estudo dos animais nos colocam nesse começo de entendimento (necessitam de dois séculos, portanto, para alcançar a premonitória suspeita de Leibniz). Pois nós poderíamos pensar, sentir, querer, recordar, poderíamos igualmente "agir" em todo sentido da palavra: e, não obstante, nada disso precisaria nos "entrar na consciência". A vida inteira seria possível sem que, por assim dizer, ela se olhasse no espelho: tal como, de fato, ainda hoje a parte preponderante da vida nos ocorre sem esse espelhamento - também a vida pensante, sensível e querente, por mais ofensivo que isto soe para um filósofo mais velho. ${ }^{110} /$... $/$

Viver sem consciência é viver sem espelho, sem a faculdade auto-reflexiva ligada ao sujeito moderno. No mais, é importante ressaltar que, em Nietzsche, consciente não se opõe a inconsciente. Este último termo, que pressupõe dualidade entre fundo e superfície, não pertence ao vocabulário nietzschiano e só adquire teor psicanalítico no século seguinte. $\mathrm{O}$ ataque é dirigido mais à especularidade cartesiana do que à de ordem narcísica. A consciência, agora, não tem mais nada a ver com a máscara que outrora cobria abismo trágico; não é apenas superficial, mas também desnecessária, pode-se "passar sem ela":

Para que então consciência, quando no essencial é supérflua? Bem, se querem dar ouvidos à minha resposta a essa pergunta e à conjetura talvez extravagante, parece-me que a sutileza e a força da consciência estão sempre relacionadas à capacidade de comunicação de uma pessoa (ou animal), e a capacidade de comunicação, por sua vez, à necessidade de comunicaşão: mas não, entenda-se, que precisamente o indivíduo mesmo, que é mestre justamente em comunicar e tornar compreensíveis suas necessidades, também seja aquele que em suas necessidades mais tivesse de recorrer aos outros. ${ }^{111} / \ldots /$

\footnotetext{
110 A gaia ciência (1882), \ 354. Quanto à “premonitória suspeita de Leibniz”, Nietzsche esclarece três seções à frente, \357: "A incomparável percepção de Leibniz, com a qual ele teve razão não só perante Descartes, mas ante todos os que haviam filosofado até então - de que a consciência é tão-só um accidens [acidente] da representação, não seu atributo necessário e essencial; que portanto isso que denominamos consciência constitui apenas um estado de nosso mundo espiritual e psíquico (talvez um estado doentio) e de modo algum ele próprio."

111 Idem.
} 
Consciência, assim, é um artifício desenvolvido unicamente para facilitar o acesso ao outro, criando pontos de passagem em suas fronteiras. Tal artifício torna-se sempre mais elaborado, refinado não só pela complexidade das linguagens e signos, mas também pelo seu uso. De parentesco técnico, tende a se multiplicar ao infinito, gerando um excedente de possibilidades comunicativas que nem mesmo seus fundadores dão conta de controlar e utilizar. Mas nem tudo está perdido. Considerando-se que outros tipos, menos comunitários e comuns, partilham do mesmo ambiente e época que todos os outros, resta-lhes tomar para si esse excesso da cultura. O que foge ao controle dos medianos é aproveitado, rapinado por espíritos livres, homens criadores, artistas. Utilizado enfim por aqueles que entendem que a vida é esbanjadora, excessiva, transbordante:

Mas bem me parece ser assim no que se refere a raças inteiras e gerações sucessivas: onde a necessidade, a indigência, coagiram longamente os homens a se comunicarem, a se entenderem mutuamente com rapidez e finura, acaba por haver um excedente dessa força e arte da comunicação, como que uma fortuna (Vermögen) que pouco a pouco se acumulou e agora espera por um herdeiro que a gaste perdulariamente ( - os assim chamados artistas são esses herdeiros, do mesmo modo que os oradores, pregadores, escritores: todos os homens que sempre vêm no final de uma longa série, sempre "nascidos tarde", no melhor sentido da palavra e, como foi dito, por essência perdulários). ${ }^{112} / \ldots /$

Após observar, como que entre parênteses, a presença de tais homens de exceção, Nietzsche volta aos detalhes genealógicos da consciência e suas implicações na hierarquia das forças:

Suposto que essa observação seja correta, posso passar à suposição de que consciência em geral só se desenvolveu sob a pressão da necessidade de comunicação - que previamente só entre humanos (entre mandante e obediente em particular) ela era necessária, era útil, e também que somente em

112 Idem. 
proporção ao grau dessa utilidade ela se desenvolveu. Consciência é propriamente uma rede de ligação entre homem e homem - apenas como ela teve de se desenvolver: um ser solitário e predatório não precisa dela. O fato de nossas ações, pensamentos, sentimentos, mesmo movimentos nos chegarem à consciência - ao menos parte deles - é conseqüência de uma terrível obrigação que por longuíssimo tempo governou o ser humano: ele precisava, sendo o animal mais ameaçado, de ajuda, proteção, precisava de seus iguais, tinha de saber exprimir seu apuro e fazer-se compreensível - e para isso tudo ele necessitava antes de "consciência", isto é, "saber" o que lhe faltava, "saber" como se sentia, "saber" o que pensava. ${ }^{113} /$... $/$

Sabedor assim de suas carências, o homem abre caminhos para outros saberes, decorrentes do primeiro ("conhece a ti mesmo"). Esta seria talvez a origem do espírito científico - origem de uma fabulação envolvendo noções como precisão, conhecimento e verdade. No entanto, o que se pensa conscientemente não contempla a inteireza do pensar corporal. Mais tarde, em Além de bem e mal, Nietzsche dirá que “um pensamento vem quando 'ele’ quer e não quando 'eu’ quero",114, portanto depende mais de disposições físicas e pulsionais do que racionais. No plano consciente desenvolvem-se linguagens, artifícios verbais de todas as ordens e mesmo mímicas, odores, traços antes indecifrados da expressão. Ali tudo se torna cognoscível, aparente, desvendável. Traduz-se a expressão em signos, pedaços atomizados de sentido e, estes, em mensageiros últimos da verdade:

Pois, dizendo-o mais uma vez: o ser humano, como toda criatura viva, pensa continuamente, mas não o sabe; o pensar que se torna consciente é apenas a parte menor, a mais superficial, a pior, digamos: - pois apenas esse pensar consciente ocorre em palavras, on seja, em signos de comunicação, com o que se revela a origem da própria consciência. Em suma, o desenvolvimento da linguagem e o desenvolvimento da consciência (não da razão, mas apenas do tomar-consciência-de-si da razão) andam lado a lado. Acrescente-se que não é somente a linguagem que serve de ponte entre homem e homem, mas

\footnotetext{
113 Idem.

114 Além de bem e mal (1886). \17.
} 
também o olhar, o toque, o gesto; o tomar-consciência de nossas impressões dos sentidos em nós mesmos, a força de poder fixá-las e como que colocá-las fora de nós, aumentaram na mesma medida em que cresceu a urgência de transmiti-las por outros signos. ${ }^{115}$

$\mathrm{Na}$ metade seguinte desta seção, Nietzsche aponta para desdobramentos modernos, ligados ao espírito gregário, ao enfraquecimento da espécie e à noção socrática de conhecimento transmudado na ciência do final do século XIX, no surgimento de pensamentos como o evolucionismo, a termodinâmica e a psicologia. Tal mundo, dominado pelos fracos, é alimentado por um círculo vicioso: maiores são as carências, mais complexas são as tramas comunicativas e a complexidade dos signos, das linguagens, da fala, das entonações, dos gestos. Porém é importante lembrar que essa "espécie enfraquecida" de humanos desenvolve para si contínuos disfarces, pois quer parecer forte e dominante. De fato, ela domina através de seus ardis e invenções na linguagem: "O homem inventor de signos é ao mesmo tempo o homem cada vez mais agudamente consciente de si mesmo; somente como animal social o homem aprendeu a tomar consciência de si - ele o faz ainda, ele o faz cada vez mais." ${ }^{\prime 16}$ A partir daí, Nietzsche reitera incisivamente que se trata de um engodo metafísico: “- Meu pensamento é, como se vê: a consciência não faz parte da existência individual do homem, mas antes daquilo que nele é natureza de comunidade e de rebanho."117

E por mais que tal ou tal indivíduo pense agir "individualmente", não faz mais do que reproduzir o mediano, num movimento em que a perspectiva gregária retorna sobre ele como um bumerangue. Toda efetividade, por mais intensa e vigorosa, quando traduzida para a consciência torna-se inevitavelmente algo "raso, ralo, relativamente tolo, geral, signo, marca de rebanho”, pois este está relacionado a "uma grande, radical corrupção, falsificação e generalização". ${ }^{118}$ Como tudo o que é vulgar (gemein), a consciência tende a se multiplicar, a crescer vertiginosamente e para

\footnotetext{
115 A gaia ciência.Opus cit. \ 354.

116 Idem.

117 Idem.

118 Idem.
} 
todos os lados, confundindo-se com os destinos da própria civilização. Tudo parece tomar a direção de uma doença generalizada, sem terapia disponível, pois os refinamentos da cultura estão ao seu dispor: ciência, gramática, fenomenomanias. É com esta advertência que o filósofo conclui a seção:

Afinal, a consciência crescente é um perigo; e quem vive entre os mais conscientes europeus sabe até que é uma doença. Não é, como se nota, a oposição entre sujeito e objeto que aqui me interessa: essa distinção deixo para os teóricos do conhecimento que se enredaram nas malhas da gramática (a metafísica do povo). E menos ainda a oposição entre fenômeno e "coisa em si”: pois estamos longe de conhecer o suficiente para assim separar. Não temos um órgão para o conhecer, para a "verdade": nós "sabemos" (ou cremos, ou imaginamos) exatamente tanto quanto pode ser útil ao interesse da grege humana, da espécie: e mesmo o que aqui se chama "utilidade" é, afinal, apenas uma crença, uma imaginação e, talvez, precisamente a fatídica estupidez da qual um dia pereceremos. ${ }^{119}$

\section{9}

Zaratustra é um profeta heimatlos, sem pátria. "Aos trinta anos deixou sua

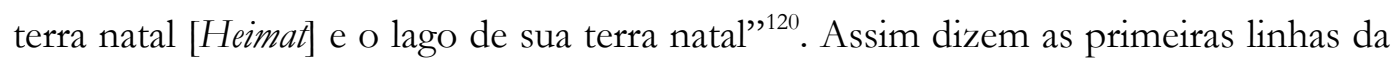
obra de Nietzsche que se pretende "para todos e para ninguém". É na solidão que encontra a pátria eletiva de uma vida andarilha, cujo fito é levar aos homens o ensinamento do eterno retorno. Mas, como autêntico solitário e habitante de altas montanhas e frias cavernas, Zaratustra não cessa de procurar lugar ou disposição que o faça sentir-se em casa. Tal é a ambivalência de um destino que não permite trégua. Em um fragmento do mesmo período está: "Sempre busquei apenas meu lar [Heim], esta é minha mais pesada prova [Heimsuchung.." ${ }^{121}$ A estrangeiridade e a inquietude

\footnotetext{
119 Idem.

120 NIETZSCHE. Assim falou Zaratustra (1883-1885). Tradução consultada de Mário da Silva. Rio de Janeiro: Civilização Brasileira, 1986.

121 Fragmentos póstumos, julho de 1882 ao inverno de 1883-1884. VII, 17 (80). No original: „Ich suchte immer nur mein Heim, das ist meine schwerste Heimsuchung." Uma variante do mesmo texto aparece também na quarta parte do Zaratustra, no capítulo intitulado "A sombra”.
} 
são concomitantes à busca permanente por laços, vínculos que se dêem além do bem e do mal. Sim, Zaratustra deseja se comunicar - mas não com cadáveres que tenha de carregar nas costas. Ele quer companheiros de viagem, humanos terríveis [unbeimlich] dispostos à partilha de experiências igualmente terríveis.

Que traz portanto de tão relevante a temática do lar e da pátria à trajetória de um eremita? Aqui é preciso atentar às sutilezas da redação nietzschiana, sobretudo ao uso do termo Heim, traduzido como casa ou lar, e de suas derivações. De início, a pequena coleção pode ser de algum auxílio: Heimat: pátria, terra natal; Heimatlosigkeit. desterro; heimatlos: sem-pátria, desterrado; Heimweb: saudade, ou em sentido literal, a dor do lar deixado para trás; Heimatvertriebene: exilado, refugiado; Geheimnis: segredo, sigilo, mistério; geheim: secreto; heimlich: oculto, escondido; heimisch: familiar, caseiro; heimkehren: voltar, regressar à casa; heimz̧ablen: vingar-se. De complicada tradução é das Unheimliche que, como vimos no primeiro capítulo, condensa grande conteúdo filosófico. Decomposta, a palavra Un-heim-lich tem em Heim o radical, ao qual se acrescenta o prefixo privativo un e o sufixo adverbial lich. Esse substantivo de gênero neutro significa estranho, terrível, assombroso, inquietante; aparece no uso cotidiano quase sempre adjetivado e de maneira tão diluída que se pode, por exemplo, dizer que algo é “unheimlich schön”, isto é, terrivelmente belo.

No prólogo de Zaratustra encontra-se: "Assombrosa [unheimlich] é a existência humana e ainda sem qualquer sentido: um bufão pode levá-lo à fatalidade." ${ }^{122}$ Por isso o profeta se inquieta, quer ensinar aos humanos “o sentido de seu ser", isto é, o além-do-homem. Mas se sente demasiado distante, estrangeiro mesmo entre seus próximos: "Ainda sou para os homens um ponto intermediário entre um doido e um cadáver." "123 Certamente o "sentido" a ser ensinado não é nenhum valor teleológico tampouco teológico, mas da ordem do vir-a-ser e da afirmação corporal; enfim, um sentido que considere todos os sentidos. O que se apresenta, neste prólogo e ao longo da obra, é uma grande luta contra a moral compassiva e os ideais cristãos. Várias são as referências, irônicas ou trans-tornadas, a passagens bíblicas. Quando Nietzsche/Zaratustra diz, no fragmento supracitado, que a busca do lar é a sua mais dura prova, há que se considerar essa busca como destino: a palavra por ele escolhida

\footnotetext{
122 Zaratustra. Prólogo, $\$ 7$.

${ }^{123}$ Idem.
} 
para dizer "prova" é Heimsuchung, que significa também visitação ou anunciação. Assim, para o filósofo, procurar o lar, heim-suchen, é sua alta tarefa e designação.

Mas que tipo de lar almeja um tal espírito, despatriado e sempre a caminho? Em A gaia ciência, o filósofo já delineia seu ideal de morada, que mais tarde será retomado no Zaratustra: "Eu não construiria uma casa para mim (e é próprio da minha felicidade não possuir uma!). Se tivesse de fazê-lo, porém, a construiria como certos romanos, bem junto ao mar e nele penetrando - eu bem gostaria de partilhar segredos com esse belo monstro." ${ }^{124}$ Pois bem, não é de seu feitio ter uma casa que ofereça abrigo ou proteção. Ao contrário, o perigo lhe atrai, de modo que aceitaria somente uma casa que avançasse sobre o mar, belo monstro [Ungehener] com o qual teria segredos [Heim-lichkeiten] em comum. Todo sentir-se em casa, todo traço de familiaridade para Nietzsche são válidos como afirmação de não-familiaridade, de Unheimlichkeit ${ }^{125}$. É assim que vida e pensamento se conjugam, tomando caráter experimental e em total acordo com o nomadismo do filósofo. Vale lembrar que, sobretudo a partir do período de Aurora (1881), Nietzsche se converte no filósofo andarilho por excelência, hábito que durará até o fim de sua vida produtiva: percorre a Itália do Piemonte à Sicília; passa temporadas na Provença e no sul da França; nos verões, habita um modesto quarto de pensão no povoado de Sils Maria, nos Alpes suíços entre Saint Moritz e o lago de Silvaplana. Por outro lado, evita tanto quanto possível o clima e a alimentação de sua terra natal, a Alemanha.

Do mesmo modo que vida e pensamento caminham juntos, a escolha das paisagens, comida, bebida, companhia e hospedagem obedece a um mesmo princípio hierárquico, tonificante, ligado ao que Nietzsche chama de grande saúde: "uma [saúde] tal não se tem, mas constantemente se adquire e é preciso adquirir, pois sempre de novo se abandona e é preciso abandonar..."126 No corpo não há nada de permanente; inclusive com a própria saúde é preciso ser pródigo, conquistá-la e deixá-la repetidas vezes. O mesmo não acontece com os homens médios, pois nestes as disposições corporais seguiriam, no limite, os destinos da civilização: sua tendência é baixar o metabolismo, assentar-se, construir refúgios, lares que estejam em

\footnotetext{
124 A gaia ciência, S 240, “À beira mar”.

125 Daqui em diante, as palavras Unheimlich e Unheimlichkeit serão algumas vezes utilizadas diretamente em alemão, visando conservar sua multiplicidade semântica.

126 A gaia ciência, \382, "A grande saúde".
} 
concordância com uma vida rasa, plana, doméstica. Por isso Nietzsche também faz crítica à arquitetura ocidental: "Se quiséssemos e ousássemos uma arquitetura conforme a natureza de nossa alma (somos covardes demais para isso!) - então o labirinto seria o nosso modelo!"127 Em resumo, de que valeria um lugar que não fosse ameaçado por um terrível minotauro e não proporcionasse um contínuo perder-se?

Nos momentos de alta solidão, o filósofo crê não estar sozinho em sua tarefa. Ao menos como lance probabilístico, Nietzsche espera encontrar ao longo de suas andanças tipos que se aparentem a Zaratustra, o mestre da transvaloração de todos os valores. Desta forma estaria constituída uma comunidade, não de iguais, mas de humanos unidos por afinidades eletivas e disposições corporais próximas. Não se trata ainda de sobre-humanos (Übermenschen), mas daqueles que o anunciam, que preparam o terreno para uma nova moral escrita sobre novas tábuas. Tal é a perspectiva nietzschiana de uma comunicação possível: entre companheiros de viagem ou, quem sabe, entre discípulo e mestre - sendo que o discípulo, neste caso, não é quem segue o mestre, mas quem o renega após ter aprendido a lição. Aqui o filósofo propõe uma nova Paidéia ou formação civilizatória (Bildung), restituindo aos humanos o bem do qual estiveram tanto tempo órfãos.

É no prólogo de Assim falava Zaratustra que se anuncia esse desejo ${ }^{128}$. Após ter abandonado sua terra natal, vivido durante anos numa caverna e vagado por solitariamente por países estranhos, o profeta desce em direção aos homens. Com eles quer compartilhar experiências e aquisições. Mas são mal-fadadas as primeiras tentativas: vai à praça do mercado, onde não encontra interlocutores, mas sim tagarelas e sátiros; afeiçoa-se a um acrobata, pois este parece caminhar sobre toda a humanidade, sobre uma "corda atada entre o animal e o além-do-homem"129. Mas o equilibrista cai e morre. Zaratustra o leva nas costas, pensando ter encontrado a primeira alma-irmã de sua longa viagem. Decepciona-se quando percebe ter levado consigo apenas um peso morto. Neste momento, anuncia as condições para aqueles

\footnotetext{
127 Aurora, $\int 169$.

128 Uma leitura valiosa deste prólogo e de suas relações com a comunicação em Nietzsche está no artigo de Scarlett MARTON: "Em busca do discípulo tão amado. Uma análise conceitual do prólogo de Assim falava Zaratustra". In: Impulso - revista de ciências humanas da Unimep, número 28. Piracicaba, 2001. Pág. 21-32.

129 Assim falava Zaratustra. Prólogo, \4.
} 
que quiserem com ele seguir: "Uma luz raiou em mim: de companheiros, eu preciso, e vivos - não de companheiros mortos e cadáveres, que levo comigo aonde quero. Preciso, sim, de companheiros vivos, que me sigam porque querem seguir a si mesmos - e para onde eu queira." ${ }^{\text {130 }}$ Essencial é que não sejam seguidores de rebanho, pois o próprio Zaratustra "não deve tornar-se pastor e cão de um rebanho!" ${ }^{131}$ Longe de qualquer disposição compassiva ou reativa, o que vale é a aposta no acaso e na afirmação incondicional da vida: "Quero unir-me aos que criam, que colhem, que festejam; quero mostrar-lhes o arco-íris e todas as escadas do alémdo-homem."132

Nessa união algumas relações são privilegiadas: companheiros de viagem, mestre e discípulo, autor e leitor. Relações, bem entendido, e não comunhões. Nietzsche sabe que uma comunicação total é impossível. O que se comunica é unicamente a superfície do que já está superado, morto. No capítulo intitulado "O viandante", Zaratustra diz que "só se vive a experiência de si mesmo". É neste sentido que a partilha se torna mais rica, pois ambos os lados se sabem inexoravelmente possuidores de suas vivências, incapazes de transferi-las em plenitude. Partilhar ou comunicar, assim, significa tornar comum a própria condição, sua finitude. Pressupõe também o reconhecimento do outro como o que há de mais próximo e ao mesmo tempo de mais distante. A justa expressão deste pathos da distância seria a amizade: "No amigo deve-se ainda honrar o inimigo. Podes acercarte do teu amigo sem bandear-te para o seu lado? Deve-se, no amigo, ter o melhor inimigo. Deves estar com o coração mais perto dele do que nunca, quando a ele te opões." 133 Noutro trecho, o profeta ensina o amor ao distante: "Não é o próximo o que vos ensino, mas o amigo. Que seja o amigo para vós a festa da Terra e um presságio do além-do-homem", e conclui, "Meus irmãos, eu não vos aconselho o amor do próximo, aconselho-vos o amor do distante." ${ }^{134}$ A amizade teria assim caráter bem diverso do amor. Este último, como já expresso em A gaia ciência, implica em propriedade e cobiça: "Nosso amor ao próximo - não é ele ânsia por nova propriedade? E igualmente o nosso amor ao saber, à verdade, e toda ânsia por

\footnotetext{
130 Ibid. Prólogo, \9.

${ }^{131}$ Idem.

132 Idem.

133 Zaratustra. "Do amigo".

134 Zaratustra. "Do amor ao próximo".
} 
novidades?"135 Quanto à amizade, seria uma espécie rara de continuação do amor, cujos envolvidos são impulsionados por uma "elevada sede conjunta de um ideal acima deles: mas quem conhece tal amor? Seu verdadeiro nome é amizade.”"136

Em nome desse laço precioso, a amizade, Zaratustra se despede daqueles que se dizem seus discípulos: “Agora sigo sozinho, meus discípulos! E vós também, agora ide embora sozinhos. Assim o quero." ${ }^{137}$ O bom aluno é, enfim, aquele que não precisa de nenhum mestre, que segue por si próprio e desbrava caminhos antes desconhecidos. O bom mestre, por sua vez, é aquele que ensina a liberdade e a magnitude de acolher os pensamentos como numa espécie de dança. Ora, lembremos que Zaratustra é como Dioniso, um filósofo dançarino. Não quer seguidores e sim parceiros. Assim adverte: "Retribui-se mal um mestre quando se permanece sempre e somente discípulo." ${ }^{\prime 38}$ Ele quer, enfim, o que somente a proximidade dos distantes pode oferecer: "Agora eu vos mando perder-vos e achastes a vós mesmos; e somente quando me tiverdes todos renegado eu voltarei a vós. Em verdade com outros olhos, meus irmãos, eu procurarei então os meus perdidos; com um outro amor eu vos amarei então."

Zaratustra se propõe comunicar aos incomunicáveis, aos homens mais solitários de seu tempo ou, mais provavelmente, àqueles que ainda virão, filhos do futuro. Talvez seja este o sentido do subtítulo do livro, "para todos e para ninguém". Embora árdua a solidão da vida andarilha, esta é aconselhada ou prescrita aos interlocutores mais argutos. Num fragmento póstumo está: "Você é uma estrela? Então precisa ser também andarilho e sem-pátria." ${ }^{139}$ Tal é o intuito de sua comunicação, de sua "descida" ao mundo raso das palavras e do corte consciente. Sem isso, não seria possível anunciar as principais descobertas de seu percurso: a transvaloração de todos os valores, o eterno retorno do mesmo e o além-do-homem. Causa mais do que justificada, ao menos no contexto da obra, e que permite ao convalescente se consolar: "Como é agradável que existam palavras e sons; não são, palavras e sons, arco-íris e falsas pontes entre coisas eternamente separadas?"140 Ou

\footnotetext{
135 A gaia ciência, $\int 14$.

136 Idem.

137 Zaratustra. "Da virtude que dá", \ 3.

138 Idem.

139 Fragmentos póstumos. Maio-junho de 1883, VII, 9 (45).

140 Zaratustra. "O convalescente".
} 
ainda se entreter: "Não foram presenteadas as coisas com nomes e sons, para que o homem se recreie com elas? Falar é uma bela doidice: com ela o homem dança sobre todas as coisas." ${ }^{141}$ Essa bela doidice consiste, pois, no domínio de um estilo apropriado aos que têm em comum a experiência do descomunal e do autoultrapassamento. Não é qualquer fala que chega a tais ouvidos seletos. É preciso ser hábil no uso da máscara, das pausas, do ritmo. É importante não causar alarde tampouco curiosidade. Ao mesmo tempo, deve haver um tom de humor e leveza que sirva de alivio para existências tão tensas.

Mas não é somente em torno dos humanos que se dá o ocaso de Zaratustra. Ele se ocupa de tudo o que vive, de tudo o que promete e traz vida. Graças a seu nomadismo, faz de toda a Terra um lar. Pode igualmente trocar segredos com o monstruoso mar e conversar pela manhã com seus animais, a águia e a serpente. No mais, depara-se com diferentes personagens e paisagens, usando de diversas linguagens como se trocasse de pele. De sua sombra ouve: "Contigo desaprendi a fé nas palavras, nos valores e nos grandes nomes. Quando o diabo muda de pele, não perde, a pele velha, também o nome? Porque este também é pele. O próprio diabo talvez seja - pele."142 Assim, ao trocar de peles e de linguagens, ao utilizá-las conforme os ouvintes e suas compleições, Zaratustra faz do estilo um grande aliado para comunicar estados internos, fazer enfim com que todo o pathos da existência venha à tona. A respeito de tal perspectivismo e pluralidade de afetos, Scarlett Marton faz a seguinte consideração: "Zaratustra fala em circunstâncias diversas e de diferentes maneiras. Discursa para o povo reunido na praça do mercado, dirige-se aos discípulos e, por vezes, a apenas um em particular, entretém-se com várias personagens que cruzam seu caminho." ${ }^{143}$ Contudo, continua a autora, "seria desmedido entender esse falar, também presente no título do livro, como mera

\footnotetext{
${ }^{141}$ Idem.

142 Zaratustra. "A sombra".

143 MARTON, Scarlett. Opus cit. Pág. 24. Sobre a questão do estilo, a autora acrescenta: "Ele [Nietzsche] entende estilo como sintoma. Enquanto manifestação de um estado, de um pathos, o estilo indica quais impulsos dominam o autor num determinado momento, quais afetos dele se apoderam e, por conseguinte, quais estimativas de valor nele se expressam. Daí decorre que não há um estilo, qualquer que seja, bom para todos os autores, e sequer um único estilo bom para o mesmo autor. Há tantos estilos quanto estados. Quem acredita existir um estilo bom em si não passa de idealista; quem julga haver um estilo universalmente bom nada mais faz do que revelar os impulsos que o dominam. "Bom", afirma o filósofo [em Ecce Homo], "é todo estilo que realmente comunica um estado interno, que não se engana quanto aos signos, quanto ao ritmo dos signos, quanto aos gestos"."
} 
necessidade de comunicar-se." ${ }^{144}$ Afinal, "Zaratustra fala, mas também canta; discursa e monologa; tem interlocutores e volta-se para si mesmo; conversa com seus animais e troca segredos com a vida. E, na maior parte das vezes, o falar esconde mais que o calar; o silêncio revela mais que as palavras. ${ }^{145}$

Através da personagem (que não hesita em tomar a voz do autor), Nietzsche faz transparecer o juízo que tem sobre sua época: décadence. Contudo, a obrigação de viver num tempo de homens fracos e pensamentos igualmente fracos é acolhida afirmativamente: ele sabe que a solidão é o que lhe há de mais próprio e não poderia ser de outra forma. Sua máxima ainda é amor fati, amor ao destino e a tudo que dele advém. Se não encontra interlocutores à altura, espera-os para o futuro. E por isso se diz "extemporâneo", nascido tarde ou cedo demais. É para homens do amanhã que escreve, para aqueles que estiverem maduros, prontos para os ensinamentos terríveis de sua obra. De fato, como consideram alguns críticos, não falta nisso tudo um tom aristocrático e desejoso de reconhecimento póstumo. Em Ecce homo, torna-se clara tal aspiração: "Algum dia serão necessárias instituições onde se viva e ensine tal como entendo o viver e o ensinar: talvez se criem até cátedras para interpretação do Zaratustra."146 Segundo Sarah Kofman, mesmo cem anos depois, a idéia ainda é utópica, impraticável: "Considerando o que ainda hoje é a universidade, tal reconhecimento institucional e universitário é portanto a última coisa que Nietzsche poderia esperar; e imaginar que se pudesse criar uma cátedra especializada na interpretação de seu Zaratustra é sinal de pura utopia."147 Para esta autora, "isso implicaria numa perturbação completa de perspectivas e numa avaliação completamente outra do que é pequeno ou grande"148, perturbação que as sociedades ocidentais do século XX também preferiram não experimentar.

\subsection{0}

Após o Zaratustra, Nietzsche empreende outros ataques, agora diretamente contra a domesticação do homem. Intensifica a crítica à consciência. Afinal, aí está o

\footnotetext{
144 Idem.

${ }^{145}$ Idem.

146 Ecce homo, "Por que escrevo livros tão bons", $\mathbb{\int} 1$.

147 KOFMAN, Sarah. Explosion II: les enfants de Nietzsche. Paris: Galilée, 1993. Pág. 16.

148 Idem.
} 
fator gregário que dá vazão a fenômenos que ele considera nefastos: a má consciência e o ideal ascético. Se a civilização é seu alvo, nenhum aspecto de sua constituição moderna deve escapar: religião, política, educação, ciência, hábitos cotidianos, moral. Para isso põe em marcha seu procedimento genealógico, nesta fase já suficientemente amadurecido. Em tal contexto, a comunicação aparece como instrumento de uma cultura decadente, ardil de traço técnico que passa a se desenvolver de maneira assustadora - e mesmo nauseante - a partir dos ideais iluministas. O seguinte fragmento dispensa explicações: "Vomitus matutinus dos jornais." ${ }^{149}$ Acompanhando tal espírito do tempo, o tipo humano rastreado por Nietzsche é o erudito. Este último, além de ler jornais pela manhã, dedica seu tempo à pequena política de caráter nacionalista, ao apaziguamento dos instintos e a tudo o que levar ao "melhoramento" da humanidade. Mas isso não tem nada a ver com o que filósofo espera da cultura, não condiz com a imagem de um arco teso cuja flecha aponta para o vir-a-ser. Em Para além de bem e mal, o filósofo volta a afirmar a Unheimlichkeit da existência humana. Desta vez, entretanto, pontua o caráter técnico como coadjuvante nesse trabalho de adestramento humano:

O homem, um animal complexo, mendaz, artificial, intransparente, e para os outros animais inquietante [unbeimlich], menos pela força que pela astúcia e inteligência, inventou a boa consciência para chegar a fruir sua alma como algo simples; e toda moral é uma decidida e prolongada falsificação, em virtude da qual se torna possível a fruição do espetáculo da alma./.../150

O cenário da Europa do fim do século XIX é para Nietzsche pouco promissor. Um grande espetáculo moral toma conta dos ambientes. Para escapar aos ardis do homem culto, é preciso que o chamado "espírito livre" se torne oculto. Daí novamente o investimento no uso da máscara, não em sua versão trágica, mas como estratégia moderna contra a décadence. Ainda em Para além de bem e mal está: "Tudo que é profundo ama a máscara: as coisas mais profundas têm mesmo ódio à imagem e ao símile."151 Mas não se trata de vestir qualquer disfarce: "Esse homem oculto, que

\footnotetext{
149 Fragmentos póstumos. Do período do outono de 1887 até março de 1888. VIII, 11 (17).

150 Para além de bem e mal, \$ 292.

151 Ibid., \ 40.
} 
instintivamente usa a fala para calar e guardar, e é incansável em esquivar-se à comunicação, deseja e solicita que uma máscara ande em seu lugar." ${ }^{152}$

Por outro lado, tanto mais elaboradas as formas de comunicação, mais vulgares os seus interlocutores. As linguagens seriam, assim, desenvolvidas de acordo com as necessidades de cada grupo, com as vivências de mesma natureza a serem partilhadas. Neste período, diferentemente do que já havia exposto em A gaia ciência, Nietzsche mostra que a comunicação é fruto não somente da evolução de indivíduos fisicamente mal-dotados, mas também de um refinado processo de hierarquia de valores em que predomina a vulgaridade. Enfim, agora toma força e clareza a antiga investida nietzschiana contra a moral compassiva. Nesta direção, seria ingênuo pensar que o uso de uma mesma língua é suficiente para o entendimento mútuo: os códigos valem somente quando há um fundo de experiências semelhantes, quando indivíduos de um grupo têm em comum os mesmos preceitos morais, os mesmos valores. A linguagem apenas encurta o caminho para transmissão de tais valores, que já estão historicamente enraizados na comunidade:

/.../ Os indivíduos de um mesmo povo se entendem melhor do que membros de povos diversos, mesmo que estes se sirvam da mesma língua; ou melhor, quando as pessoas viveram juntas por muito tempo, em condições semelhantes (clima, solo, perigos, necessidade, trabalho), nasce algo que "se entende", um povo. Em todas as almas, um mesmo número de vivências recorrentes obteve primado sobre aqueles de ocorrência rara: com base nelas as pessoas se entendem, cada vez mais rapidamente - a história da linguagem é a de um processo de abreviação -; com base nesse rápido entendimento as pessoas se unem, cada vez mais estreitamente. ${ }^{153}$

Prova maior de que a linguagem nada acrescenta, apenas condensa, está no “temor ao mal-entendido" típico dos amigos muito próximos ou dos amantes. Nietzsche considera que tais relações não duram muito tempo; acabam "tão logo se percebe que um dos parceiros, usando as mesmas palavras, sente, pensa, pressente,

\footnotetext{
152 Idem.

153 Ibid. \ 268.
} 
anseia, receia de modo diferente do outro." ${ }^{154}$ Assim, a linguagem obedeceria antes à vontade dos impulsos, sejam eles individuais ou comunitários. É necessário portanto distinguir "quais são os grupos de sensações que dentro de uma alma despertam mais rapidamente, tomam a palavra, dão as ordens"155, pois é isso o que "decide a hierarquia inteira de seus valores, determina por fim a tábua de bens."156 Preponderante nessa passagem dos impulsos (Triebe) para a linguagem é a necessidade. Graças a ela os humanos se põem continuamente em comunicação. Os menos necessitados, fortes ou dispostos ao desconforto da vida solitária seriam, assim, menos dotados à comunicação. A necessidade é para Nietzsche, embora a serviço da vulgaridade, fonte assombrosa de força:

Supondo então que desde sempre a necessidade aproximou apenas aqueles que podiam, com sinais semelhantes, indicar vivências semelhantes, necessidades semelhantes, daí resulta em geral, que entre todas as forças que até agora dispuseram do ser humano, a mais poderosa deve ter sido a fácil comunicabilidade da necessidade, que é, em última instância, o experimentar vivências apenas medianas e vulgares. Os homens mais semelhantes, mais costumeiros, estiveram e sempre estarão em vantagem; os mais seletos, mais sutis, mais raros, mais difíceis de compreender, esses ficam facilmente sós, em seu isolamento sucumbem aos reveses, e dificilmente se propagam. ${ }^{157}$

Munidas de tal poder, as comunidades difundem seus ideais, propagam seu modo de vida. E o fazem através de indivíduos cuidadosamente preparados, a quem Nietzsche chama de sacerdotes ascéticos. Na Genealogia da moral, livro qualificado pelo próprio autor como unheimlich ${ }^{158}$, o ascetismo é tomado como fundamento do

\footnotetext{
154 Idem.

155 Idem.

156 Idem.

157 Idem.

158 Ver Ecce homo, "Por que escrevo livros tão bons". Sarah KOFMAN, em seu livro Les enfants de Nietzsche, dedica um capítulo à Unheimlichkeit da Genealogia da moral. Ali, a autora pondera: "Se as três dissertações desse livro constituem o texto mais unheimlich que possa existir, é porque elas se elevam contra o que há de mais 'beimlich' [secreto] e de mais reconfortante: as crenças que passam por verdades, difundidas pelos padres. Para aqueles que crêem que o ideal é de origem celeste e divina, a Genealogia parece sair de um reino de trevas. De fato, a inspiração 'dionisíaca' do texto está para além do bem e do mal, além de deus e do diabo. Talvez seja esta sua maior Unheimlichkeit.O livro continua inclassificável, não faz parte do sistema de oposições tributárias do ideal ascético.” Pág. 305.
} 
Ocidente judaico-cristão e, por esta razão, cuidadosamente investigado. Em tal contexto, "Os sacerdotes são, como sabemos, os mais terriveis inimigos - por quê?"159 Nietzsche responde: "Porque são os mais impotentes. $\mathrm{Na}$ sua impotência, o ódio toma proporções monstruosas e sinistras [ungeheure und unheimliche], torna-se a coisa mais espiritual e venenosa." ${ }^{160}$ Contra tal veneno, finamente destilado no solo do ressentimento, o estilo cumpre papel estratégico no texto da Genealogia. O tom dionisíaco, sombrio e mesmo assustador, está presente. Não pode ser de outro modo: "Alguém quer descer o olhar sobre o segredo de como se fabricam ideais na terra? Quem tem coragem para isso?... Muito bem! Aqui se abre a vista a essa negra oficina." ${ }^{161}$ O projeto genealógico começa, então, com uma visão capaz de desbravar a obscuridade da moral, dos valores negadores da vida:

Precisamente nisso enxerguei o grande perigo para a humanidade, sua mais sublime sedução e tentação - a quê? ao nada? -; precisamente nisso enxerguei o começo do fim, o ponto morto, o cansaço que olha para trás, a vontade que se volta contra a vida, a última doença se anunciado terna e melancólica: eu compreendi a moral da compaixão, cada vez mais se alastrando, como o mais inquietante [unheimlich] sintoma dessa nossa inquietante cultura européia. ${ }^{162}$

$\mathrm{Na}$ vontade contrária à própria vontade, há uma vida que recua. O que impera, em vez do afirmativo amor fati, é um desejo de ser outro, de estar em outro lugar ou simplesmente de não ser. Nietzsche grifa: "O ideal ascético nasce do instinto de cura e proteção de uma vida que degenera." ${ }^{\text {163 }} \mathrm{E}$ para maquiar, disfarçar a todo custo essa degenerescência, faz-se obrigatória uma monumental organização ascética: cultos, ação instigada pelo medo, incentivo a atividades repetitivas, enfim, todo tipo de artifício que confira sentido à vida. O dia-a-dia dos europeus é finalmente

159 Genealogia da moral. I, $\int 7$.

${ }^{160}$ Idem.

161 Ibid. I, $\int 14$.

162 Ibid. Prólogo, \5.

163 Ibid. III, \ 13. 
transformado numa paralisia que agita, "paralysis agitans" "164, acompanhada da ideologia do trabalho como fonte de purificação e salvação. Nada mais eficaz contra a melancolia do rebanho, sentimento de quem não quer viver. Longe de medidas vigorosas e vivificantes, diz o filósofo, "emprega-se contra estados de depressão um outro training, de todo modo mais fácil: a atividade maquinal." 165 Desta forma, "a formação do rebanho é avanço e vitória essencial na luta contra a depressão."166 Tal o cenário civilizatório no qual o homem é um animal a ser domesticado, comodamente conduzido em conformações gregárias, sem que precise jamais impor grandes energias para garantir a existência. Prazer, dança e tudo o que for corporal, transbordante, não é permitido; apenas a dor e o auto-sacrifício são considerados edificantes. É assim que para Nietzsche a Terra se torna o "astro ascético por excelência" 167 , povoado por criaturas "criaturas descontentes, arrogantes e repulsivas, que jamais se livram de um profundo desgosto de si, da terra, de toda a vida, que a si mesmas infligem o máximo de dor possível, por prazer em infligir dor provavelmente seu único prazer."

Convém ficar em casa, no solo pátrio, na segurança dos seus. Todo o esforço do ideal ascético estaria em domar o que no homem é caos, guerra, luta de impulsos geradores de vida. Talvez seja esta a razão de, em algum momento da civilização, ter sido inventada a "verdade" de que o natural no homem é a gregariedade. Invenção, para o filósofo, instrumentalizada:

Supondo que fosse verdadeiro o que agora se crê como "verdade", ou seja, que $o$ sentido de toda cultura é amestrar o animal de rapina "homem", reduzi-lo a um animal manso e civilizado, doméstico, então deveríamos sem dúvida tomar aqueles instintos de reação e ressentimento, com cujo auxílio foram

\footnotetext{
${ }^{164}$ Ibid, III, \26. Nesta seção da Genealogia da Moral, Nietzsche analisa o espírito ascético europeu, mas em especial o dos alemães: "O fato de que toda espécie de charlatanismo espiritual obtenha sucesso espiritual na Alemanha de hoje tem relação com o inegável e já evidente definhamento do espírito alemão, cuja causa eu vejo em uma dieta demasiado exclusiva, composta de jornais, política, cerveja e música wagneriana, juntamente com o pressuposto para essa alimentação: a clausura e a vaidade nacionais, o forte, porém estreito, princípio de "Deutschland, Deutschland über alles", e também a paralysis agitans. A Europa hoje é rica e inventiva sobretudo em meios de excitação, parece nada mais necessitar senão estimulantes e aguardentes."

165 Ibid. III, \ 18.

166 Idem.

167 Ibid. III, \ 11

168 Idem.
} 
finalmente liquidadas e vencidas as estirpes nobres e os seus idéias, como os autênticos instrumentos da cultura. /.../ Esses "instrumentos da cultura" são uma vergonha para o homem, e na verdade uma acusação, um argumento contrário à “cultura”!

No Crepuisculo dos ídolos, texto de 1888, domesticação e moral são igualmente tratados como aliados ao ideal ascético. Nesta fase, Nietzsche se mostra ainda mais direto e pronto a expressar seu descontentamento: "Chamar a domesticação de um animal sua 'melhora' é, a nossos ouvidos, quase uma piada." ${ }^{\prime 10}$ Para ele, onde se vê humanos evoluídos e civilizados, o que há na verdade é gente supérflua, desnecessária e que se alimenta do que há de pior na superfície. Lembremos Zaratustra: "Olhai esses supérfluos! Estão sempre enfermos, vomitam fel e lhe chamam 'jornal'. Devoram-se uns aos outros e não podem, sequer, digerir-se." ${ }^{\text {171 }}$ Todo o aparato que constitui a comunicabilidade faria parte, assim, da "piada" da domesticação. Em tal processo, há uma grande valorização da memória, das marcas, das promessas, dos dados conscientes. Por outro lado, o que é impulso e vivência presente, intensidade e força vital, são colocados à margem pelo ideal ascético.

Para comunicar, diz Nietzsche, é preciso investir-se de um certo autodesprezo; aceitar que o instante morreu, que se chegou ao fim. A comunicação não passaria, deste modo, de ritualização em homenagem a um momento morto. Trabalho de luto. Quanto a isto, Nietzsche admite para si próprio a necessidade de comunicar: mas só com relação ao que está morto e superado. O resto é tagarelice:

Não nos estimamos mais o bastante quando nos comunicamos. Nossas vivências mais próprias não são nada tagarelas. Estas não poderiam comunicar-se, se quisessem. É que lhes falta a palavra. Quando temos palavras para algo, também já o ultrapassamos. Em todo falar há um grão de desprezo. A fala, ao que parece, só foi inventada para o corte transversal, o

\footnotetext{
${ }^{169}$ Ibid. I, $\int 11$.

${ }^{170}$ Crepúsculo dos ídolos. "Os melhoradores da humanidade", \ 2.

171 Assim falava Zaratustra. "Do novo ídolo".
} 
mediano, o comunicativo. Com a fala já se vulgariza o falante. - De uma moral para surdos-mudos e outros filósofos. ${ }^{172}$

Parece haver, no entanto, respiradouros, tipos de comunicação capazes de ultrapassar essa vulgaridade. Mesmo que momentaneamente. Em A gaia Ciência, Nietzsche diz que "todo espírito, todo gosto mais elevado, escolhe para si os seus ouvintes quando quer comunicar-se; ao escolhê-los, impõe limites aos 'outros'."173 Não se trata de comunicação baseada na relação sujeito-objeto ou emissor-receptor, mas aquela que se dá por um tênue fio, e também por uma radical aporia, não fundada em presença, essência ou substância, que não se baseia em discurso (lógos), mas nas forças indizíveis do devir. Exige-se aí uma ética dionisíaca, transfiguradora, que opera por labirintos.

Nietzsche, após derrotar a metafísica, matar Deus, acabar com a substância, com o Estado, com indivíduo, com as instituições, ainda manteve um certo fio. O filósofo não caiu em armadilhas niilistas ou na total relativização, que anulam todos os valores. Talvez seja este o ponto que nós, humanos do século XXI, ainda não fomos capazes de entender. Todo o pós-modernismo se saiu bem na interpretação nietzschiana, mas pecou justamente com relação a esse último ponto. O fato de as instituições estarem condenadas ou mesmo diluídas não deve tirar da vida o seu impulso, o seu élan. A vida é uma potência que pretende simplesmente se afirmar, mais e mais. E nós, modernos ou pós-modernos, ainda não tivemos ouvidos para isso. Não tivemos ouvidos porque não tivemos coragem de enfrentar o labirinto, de enfrentar Dioniso, o deus-carrasco - e muito menos de afirmá-lo. No labirinto é onde se operam as pulsões escondidas, desenroladas pelo fio de Ariadne, personagem mítica, muitas vezes evocada pelo filósofo. É o lugar do inconsciente. Lá, estamos a sós com o Minotauro e não há outra saída senão enfrentá-lo. Para Nietzsche, contudo, esse estado labiríntico é algo mais do que mera comunicação; é exaltação dos impulsos (Triebe), totalidade de uma linguagem que está além da própria linguagem, além do verbo. Esta não pode ser descrita ou dominada. Dela, só nos resta o silêncio.

\footnotetext{
172 Ibid.Em "Incursões de um extemporâneo", \ 26.

173 A gaia ciência. \ 381.
} 


\subsection{1}

"A linguagem é a casa do ser. Em seu abrigo habita o homem."174

\subsection{2}

Não há domesticação sem comunicação. Os primeiros grandes media em grande escala foram as narrativas cosmogônicas, os mitos, a Paidéia, os textos sagrados. Depois, o lógos e suas derivações. Por fim, o humanismo - não só o de caracterização moderna, mas também aquele que desponta na era da técnica e do terror - se encarrega de encaminhar o plano civilizatório através de incontáveis novos meios de comunicação. Por isso, como escreve Heidegger em sua "Carta sobre o humanismo", o homem habita sob o abrigo da linguagem. Se bem que esse abrigo toma, cada vez mais, aspectos tão terríficos que acaba virando desabrigo. É assim que, para este filósofo, "o desterro [Heimatlosigkeit] se torna um destino mundial"175, restando ao homem ser um "pastor" e um "vizinho" do Ser.

Poucos responderam à polêmica carta de Heidegger. Um deles foi Peter Sloterdijk, para quem o problema de nossa auto-domesticação toma proporções inesperadas. Como num grande parque, os homens estariam agrupados na clareira (Lichtung), adestrados segundo regras específicas. A questão fundamental não é apenas dirigida à linguagem e seu abrigo, mas às habitações concretas (ou de concreto) erigidas e exibidas como marca humana por excelência:

Assim que os seres humanos começam a viver em grupos maiores e se ligam não só às casas da linguagem, mas também a casas construídas, eles ingressam no campo de força do modo de vida sedentário. Daí em diante, eles estão não só protegidos por sua linguagem, mas também domesticados por suas habitações. Erguem-se na clareira - como sua marca mais vistosa - as casas

\footnotetext{
${ }^{174}$ HEIDEGGER, Martin. "Brief über den Humanismus" [1949]. In: Wegmarken. Gesamtausgabe, vol. 12, pág. 312. No original: „Die Sprache ist das Haus des Seins. In ihrer Behausung wohnt der Mensch.“

${ }^{175}$ Ibid., pág. 339.
} 
dos homens (como os templos de seus deuses e os palácios de seus senhores). ${ }^{176}$

Quanto mais domesticado estiver este animal, maior o seu desterro, sua Heimatlosigkeit. Não só a construção de casas, mas também a transformação da linguagem poiética em linguagem técnica, dão sinais de há algo errado com o habitar. A humanização, como grande projeto, surgiria assim em meio a esta crise. Para Heidegger, o primeiro humanismo foi o dos romanos, que conferiram a si mesmos a denominação "animal racional". E sem nenhuma relação com a definição grega de homem, animal dotado de lógos. Trata-se, antes, de incursão inaugural na metafísica; isto é, do momento em que o homem (homo) passa a ser humano (bumanus). Para isso, não basta ser dotado de lógos ou com ele estar em acordo; é preciso também dominálo. Sloterdijk lembra: "No início, os humanizados não são mais que a seita dos alfabetizados e, como em muitas outras seitas, também nesta despontam projetos expansionistas e universalistas." ${ }^{177}$

Indissociável da escrita, o projeto humanista desenvolveu meios sofisticados de difusão. A amizade, mais do que nunca, garantiu vida longa às idéias: a filosofia assume o caráter de uma "longa história de cartas entre amigos." "178 Livros eram escritos como resposta a outros livros, endereçados a amigos tanto do passado quanto do futuro. E isso se deu por um período relativamente longo, pelo menos até o fim da Idade Média, quando a "seita" dos alfabetizados era formada por um número restrito de membros. Cabia então a estes a tarefa de humanizar os nãoalfabetizados. Segundo Sloterdijk, outras estratégias entraram depois em cena. Porém, colocaram a philia em segundo plano: "Nesse meio tempo, novos meios de telecomunicação político-culturais assumiram a liderança, reduzindo a uma modesta medida o esquema das amizades nascidas da escrita." ${ }^{179}$

Importante, no processo humanista, é que o homem jamais deixe de ser um animal continuamente instruído, educado. E isso o diferencia de todos os outros animais. Sua carência implícita de formação é a mola propulsora do projeto

\footnotetext{
176 Peter Sloterdijk. Regras para o parque humano: uma resposta à carta de Heidegger sobre o humanismo. São Paulo: Estação liberdade, 2000. Pág. 35.

177 Ibid., pág. 11.

178 Idem.

${ }^{179}$ Idem.
} 
civilizatório. Há uma quantidade mais ou menos determinada de influências necessárias para a formação, variável de acordo com fatores geográficos e culturais, mas ainda assim voltadas para um fim comum: afastar o humano da condição de bestialidade, torná-lo enfim humano. Influências que operam tanto por inibição como por desinibição, como assinala Sloterdijk:

O fenômeno do humanismo hoje merece atenção antes de mais nada porque nos recorda - embora de forma velada e tímida - que as pessoas na cultura elitizada estão submetidas de forma constante e simultânea a dois poderes de formação - vamos aqui denominá-los, para simplificar, influências inibidoras e desinibidoras. Faz parte do credo do humanismo a convicção de que os seres humanos são "animais influenciáveis" e de que é portanto imperativo prover-lhes o tipo certo de influências. A etiqueta "humanismo" recorda - de forma falsamente inofensiva - a contínua batalha pelo ser humano que se produz como disputa entre tendências bestializadoras e tendências domesticadoras. ${ }^{180}$

Em seu estágio avançado, o humanismo não se reconhece mais como tal. Ou pior: se esconde atrás da perversão de seus princípios. O que deveria permanecer força domesticadora toma o lugar do impulso bestializador. E vice-versa. O exemplo, dado por Heidegger e retomado por Sloterdijk, é o fascismo: "De fato, o fascismo é a metafísica da desinibição - talvez mesmo uma forma desinibida da metafísica." ${ }^{181} \mathrm{E}$, na visão de Heidegger, "o fascismo foi a síntese do humanismo e do bestialismo; isto é, a paradoxal confluência de inibição e desinibição." ${ }^{182}$ A partir de tal perversão, que acontece através de "monstruosos deslocamentos e rejeições", a questão da domesticação e formação do homem precisa ser recolocada. Os termos do humanismo não cabem mais num tal cenário mundial de desterro. Sloterdijk critica em Heidegger a idéia de que o homem é o "pastor do ser", no entanto admite neste filósofo o mérito de ter trazido à tona a questão mais relevante de seu tempo:

\footnotetext{
180 Ibid., pág. 17.

181 Ibid., pág. 31.

182 Idem.
} 
Se a bucólica pastoral ontológica de Heidegger - que já em sua época soava estranha e escandalosa - hoje parece completamente anacrônica, ainda assim, apesar de seu caráter desagradável e de sua canhestra excentricidade, ela conserva o mérito de ter articulado a questão da época: o que ainda domestica o homem, se o humanismo naufragou como escola da domesticação humana? O que domestica o homem, se seus esforços de autodomesticação até agora só conduziram, no fundo, à sua tomada de poder sobre todos os seres? /.../ Ou será que a questão sobre o cuidado e a formação do ser humano não se deixa mais formular de modo pertinente no campo das meras teorias da domesticação e educação? ${ }^{183}$

Se as teorias convencionais não satisfazem mais, onde procurar o pensamento apropriado ao problema? Nisso consiste o desafio para as ciências (humanas?) do novo século. Diz Sloterdijk: "Reconhecer a domesticação do ser humano é o grande impensado, do qual o humanismo, desde a Antigüidade até o presente, desviou os olhos." ${ }^{184}$ Mas por onde começar, ainda não se sabe. Ou talvez já se tenha começado, silenciosamente, marginalmente, para além da tábua de disciplinas hoje conhecida. Os humanos, em sua maioria, não são mais nômades e dificilmente voltarão a sê-lo. Habitam em suas próprias casas e são, na presente condição, tão domésticos quanto seus animais. De todo modo, o nomadismo parece não ser mais um estado desejável: quem não tem casa quer ter uma, sente-se à margem, excluído da civilização.

$\mathrm{O}$ teto tornou-se portanto requisito para a humanização. Aqueles que vagam não têm direito à dose diária de "influências" necessárias para sua formação. Assim se passa com os sem-teto, sem-terra, exilados, foragidos do mundo inteiro. Por outro lado, onde há casas, decide-se o destino do mundo. Lá, toma forma a arbitrariedade, determina-se no que se tornarão os humanos que nelas habitam. Não deixa de ser um tipo de clareira (Lichtung), que mostra "por quais posições os homens lutam, tão logo se destacam como seres construtores de cidades de produtores de riquezas."

Sloterdijk atribui a Platão a criação de um grande desassossego intelectual no parque humano: "Desde $O$ político, e desde $A$ república, correm pelo mundo discursos

\footnotetext{
183 Idem.

184 Ibid., pág. 43.

185 Ibid., pág 37.
} 
que falam da comunidade humana como um parque zoológico; a partir de então, a manutenção de seres humanos em parques ou cidades surge como tarefa zoopolítica." ${ }^{186} \mathrm{O}$ homem é ainda um animal, apesar de dito racional. O homem é também o senhor dos animais. E não sabe mais onde se colocar, como se portar besta já quase inclassificável. Mesmo os filósofos hesitam quanto ao seu lugar nesse parque: "O homem e os animais domésticos - a história dessa formidável coabitação ainda não recebeu um tratamento apropriado, e por isso mesmo os filósofos até hoje não souberam convir quanto a seu papel em meio a essa habitação."187 Tal é a inquietude deixada por Platão, que nunca mais pôde ser completamente apaziguada. O que se vê, como adverte e conclui Sloterdijk, é um grande abandono: "Dois mil e quinhentos anos depois da tecedura de Platão, parece que agora não só os deuses, mas também os sábios se retiraram, deixando-nos sozinhos com nossa ignorância e nosso parco conhecimento das coisas." 188

\subsection{3}

Com Vilém Flusser aprendemos que comunicação é antes uma questão de desterro do que de cidadania. Ou melhor: só se torna questão de cidadania por estar genealogicamente cravada no desterro. Este filósofo permite, com seu pensamento nômade, acesso ao avesso das teorias da comunicação demasiadamente partidárias da abertura, do espaço público (Öffentlichkeit), do solo natal e dos valores impostos por colonizadores. Sua análise realiza uma espécie de anti-autópsia dos processos comunicativos, feita de dentro para fora, do secreto rumo à pele.

A experiência da Unheimlichkeit, expressa no terror do desterro e do exílio, alimentou e mesmo constituiu em integridade o pensamento de Vilém Flusser. Portanto, suas teses sobre comunicação são indissociáveis de seu percurso filosófico. Um texto especialmente propício é "A morada ocupa o desterro", que trata das nuances entre pátria e segredo [Heimat und Geheimnis], habitação e hábito [Wohnung und Gewohnheit:

\footnotetext{
186 Ibid., pág 48.

187 Ibid., pág. 46.

188 Ibid., pág. 56.
} 
Contra meu hábito, virado e desviado pelo tema "pátria e desterro" [Heimat und Heimatlosigkeit], tentarei desta vez arejar um pouco o segredo [Geheimnis] de meu desterro. Nasci em Praga e sinto como se tivesse habitado a cidade dourada há milhares de anos. Sou judeu e a frase "no próximo ano em Jerusalém" tem me acompanhado desde a infância. Estive durante décadas envolvido na tentativa de sintetizar uma cultura brasileira vinda da mistura de culturemas europeus tanto do Leste quando do Oeste, africanos, oesteasiáticos e índios. Moro em um povoado provençal e incorporei-me às tramas de tais lugares atemporais. Cresci na cultura alemã e participo dela há alguns anos. Em resumo: sou sem pátria, pois inúmeras pátrias estão depositadas em mim. Isso se manifesta diariamente em meu trabalho. Sou habitado pelo menos por quatro línguas e me vejo solicitado e obrigado a traduzir e retraduzir tudo o que escrevo. ${ }^{189}$

Para Flusser, na civilização predominam certas inversões conceituais, perversões do pensamento. Um exemplo é a confusão que se cria entre a pátria e a casa, seguida de conseqüências complicadas como o nacionalismo e a xenofobia, em resumo, rejeição e nenhuma disposição à comunicação. Certas distinções, calcadas na vivência, são portanto imprescindíveis para dar partida ao pensamento:

Eu gostaria, o mais precisamente possível, de diferenciar "pátria" [Heimat] de "habitação" [Wobnung] - com a desagradável consciência de ter de jogar com a língua alemã. A palavra alemã "Heimat" encontra, entre as línguas que me são fluentes, apenas no tcheco "domov" um equivalente, e isso graças à pressão exercida do alemão sobre o tcheco durante séculos. Talvez o conceito "Heimat" seja familiar apenas em alemão - somente o conceito, não a vivência? Sim, inclusive sobre a vivência tenho minhas reflexões a fazer. Será que o agricultor da provençal Robion vive sua pátria rica em história (em cuja estrutura estão elementos paleolíticos tardios, neolíticos, ligúricos, gregos,

\footnotetext{
189 FLUSSER, Vilém. "Wohnung beziehen in der Heimatlosigkeit". In: Bodenlos. Eine philosophische Antobiographie Düsseldorf: Bollmann Verlag 1992. Pág. 247 -264. \1.

190 Para "habitar", em alemão, existe o verbo wohnen. A partir dele, assim como na língua portuguesa, vêm os termos relacionados habitação, hábito, habitual, respectivamente Wohnung, Gewobnheit, gewöhnlich.
} 
romanos, visigodos, burgúndigos, árabes, francos, provençais, italianos e franceses) no mesmo sentido em que os camponês viandante brasileiro vivencia sua "terra" ou que o israelense do kibutz sente sua "Israel Prometida"? 191

Existem diferentes tipos de sedentarismo. Mas todos envolvem um estar familiarizado, babituado à própria condição de habitante e cultivador, isto é, à condição daquele que põe em movimento uma cultura. Por isso o conceito Heimat talvez soe apenas em alemão familiar: somente ali, sob determinadas condições, o conceito faz morada. Conceitos surgem da ligação do homem ao seu entorno, sendo que às vezes esse entorno é arbitrariamente tomado como propriedade, apropriado e, por fim, algo pelo qual se deva lutar. Mas nem sempre foi assim, ter um teto não pressupõe ter uma terra. Aliás, são duas coisas verticalmente opostas: teto para a cabeça, chão para os pés. O ponto crucial, diz Flusser, está no fato de o homem ser um animal sedentário há muito pouco tempo: "Durante os períodos mais longos de sua existência, o ser humano foi de fato alguém que habitou, mas não um residente fixo." ${ }^{192}$ Ele pode morar em qualquer lugar, mas estando sempre a caminho:

Nós, os incontáveis milhões de migrantes (sejamos trabalhadores, refugiados, fugitivos ou intelectuais intermitentes entre um seminário e outro) não nos reconhecemos como trabalhadores externos, mas sim como sentinelas do futuro. Os vietnamitas na Califórnia, os turcos na Alemanha, os palestinos no Golfo e os cientistas russos em Harvard não parecem ser vítimas compadecidas às quais se deva ajudar a conquistar a pátria perdida, mas sim modelos cuja coragem deve ser seguida. /.../ A migração é de fato uma atividade cansativa, mas ela é também uma paixão [Leiden]. ${ }^{193}$

\footnotetext{
${ }^{191}$ FLUSSER. Opus cit. \3. Quando fala do "camponês brasileiro viandante" [der brasilianische wandernde Landarbeiter], o autor faz certamente referência aos trabalhadores rurais sem-terra. Há uma outra versão deste texto, originalmente uma conferência proferida em 1985, publicada como áudio-livro e que contém algumas diferenças com relação ao texto impresso. Ali Flusser cita, além dos trabalhadores sem-terra, os favelados e os nordestinos em São Paulo como representantes da condição nômade, igualmente refugiados e exilados de suas pátrias. In: Heimat und Heimatlosigkeit (Hörbuch). Köln: Supposé, 1999.

192 Idem.

193 Idem, \4. Na versão em áudio, o autor diz também que "o ser humano é como os ratos, cosmopolita".
} 
$/ \ldots /$

Costuma-se dizer que a Pátria é o permanente e, a moradia, o substituível, lugar colonizável. Mas o contrário é certo: pode-se trocar de pátria, ou então não ter nenhuma, mas é preciso sempre morar em algum lugar, não importa onde. Os clochards de Paris moram sob pontes, os ciganos em caravanas, os camponeses brasileiros em acampamentos, e por mais assustador que isso soe, pessoas moraram em Auschwitz. Portanto, literalmente, sem moradia morre-se. $^{194}$

Ora, o problema que se impõe é de ordem vital. Ele implica inicialmente um desnível - ou mesmo um colapso - informativo. Esse morrer, diz Flusser, impede a troca e a comunicação: "sem o teto, sem a proteção do que é costumeiro-acostumado [von Gewöhnlichem und Gewohntem], qualquer coisa nova se torna ruído; ali nada é informação e, nesse caos de um mundo desinformado, não se pode nem sentir nem pensar nem trocar." ${ }^{\prime 195}$ Graças à morada, um ethos autêntico pode se desenvolver e dosar adequadamente o habitual com o inabitual, informação conhecida com a novidade. Sem o habitar, mostra o autor, o ser humano permaneceria inconsciente, isto é, sem ser. "Habitar é o modo pelo qual, antes de tudo, eu me encontro no mundo; e isto é primário." ${ }^{196}$ A pátria, por sua vez, não é necessariamente vital. Ela é secundária e se nutre de quem nela habita:

A pátria não é portanto nenhum valor eterno, e sim a função de uma técnica específica. Mas quem a perde, sofre [leidet]. Esta pessoa está ligada à sua terra através de muitos laços, sendo que a maioria destes laços é secreta [geheim], para além de sua consciência. Quando os laços rompem ou se tornam rompidos, vive-se uma espécie de dolorosa intervenção cirúrgica no que há de mais íntimo. Quando eu saí de praga (ou melhor, quando tomei a coragem de fugir), atravessei algo como um desmoronamento do universo. /.../ Assim somos todos os nômades, saídos do desmoronamento do sedentarismo.

194 Idem.

195 Idem, \ 23.

196 Idem. 
Se para Flusser o nomadismo é uma paixão e um sofrimento, o patriotismo é uma doença. Por confundirem pátria com morada, os sedentários percebem seu solo como algo gracioso, bonito [bübsch], da mesma forma que nós todos achamos nossas casas bonitas. E então, segundo Flusser, essas pessoas confundem graciosidade [Hübschheit] com beleza ${ }^{197}$ [Schönheit: “Tal confusão se origina no fato de os sedentários estarem envolvidos com sua terra. Assim, eles não se abrem à feiúra vinda de fora, que poderia talvez se converter em beleza." O resultado de tal relação é bastante sério: “O patriotismo é antes de tudo sintoma de doença estética.",198

Com isso, no nomadismo encontra-se mais do que um modo de vida e de habitar. Nele, funda-se o único pensamento da comunicação que leva o centro para a margem, que mostra o espaço público com seus limites e saídas. Costuma-se falar em comunicação partindo da perspectiva da cidade, de quando os homens já estão pousados sobre um solo - solo por eles construído e obviamente impregnado de laços secretos. Costuma-se falar em comunicação, portanto, num sentido estritamente político. De fato, não há nada de errado nisso. No entanto, mesmo a cidade tem suas brechas e suas nostalgias do tempo nômade. Mais uma vez Flusser detecta uma inversão ou perversão conceitual: "O homem não é nenhum animal político. Ele é, ao contrário, o mais solitário de todos os animais, pois é consciente de sua morte." ${ }^{199}$ E só por isso, inábil para a vida solitária, ele se põe em estado de comunicação com os outros. Trata-se de um animal por natureza não-natural, isto é, fadado a transformar, a fazer uso da linguagem e da cultura por ele mesmo estabelecidas. Somente neste sentido, considera Flusser, "o homem pode ser chamado de animal social ou gregário, um zoon politikon"200. Além disso, "se ele não aprender a utilizar os instrumentos da comunicação (por exemplo, uma língua), será um idiota (originalmente 'pessoa privada'). Idiotia, existência humana incompleta, é carência de arte [Kunst.",201

O homem está portanto condenado a comunicar e a aprimorar seus instrumentos. Mais uma vez, o que se tem é a vocação técnica como mal-estar prometeico. Para Flusser, a comunicação humana (pois só pode falar a partir desta

\footnotetext{
197 Beleza, em alemão Schönheit, é uma categoria estética. Hübsch, por sua vez, é uma beleza cotidiana, equivalente ao inglês nice, bonitinho, simpático.

${ }^{198}$ Idem, \ 27.

${ }^{199}$ FLUSSER, Vilém. Kommunikologie. Frankfurt am Main: Fischer, 1998. Pág. 260.

200 Ibid. Pág. 9.

${ }^{201}$ Idem.
} 
perspectiva, a humana), é um processo artificial, “cujo propósito é ajudar-nos a esquecer a brutal falta de sentido de uma vida condenada à morte." ${ }^{202}$ Processo que se mantém vivo apesar de toda a falibilidade: cada um sabe que vai morrer e que, na hora da morte, nenhuma sociabilidade poderá ajudar. Tal é o vínculo do pensamento da comunicação com as filosofias da finitude. Se bem que, sob uma perspectiva inesperada: o fardo da finitude, ensina Vilém Flusser, não é ter de se deparar com o próprio fim, mas sim enfrentar o fim daqueles que amamos, do outro. É para o “outro" que estamos aqui e de sua morte nos escondemos e trememos. Cada vez que uma comunicação se efetiva entre dois seres, a morte os encara de muito perto. "É por isso que a teoria da comunicação não é uma ciência natural, mas pertence àquelas disciplinas ligadas aos aspectos ditos não naturais do homem e que, no passado, se chamavam ciências do espírito [Geisteswissenschaften]."203

Certamente, se há a diferença entre natural e não-natural é no máximo de grau e não ontológica. $\mathrm{O}$ autor tcheco elimina esses rastros de metafísica ao propor formulações de fundo heraclitiano, como: "o próprio do homem é o artifício (ou a arte)". Sim, argumenta Flusser, existem relações possivelmente "naturais" entre os humanos (como acontece na amamentação ou na relação sexual) e pode-se inclusive supor que esta seja a origem das formas de comunicação ${ }^{204}$. Essas relações podem não ser características apenas da comunicação humana, mas influenciam-na amplamente. "A comunicação humana tece em nós a rede de um mundo codificado, rede de arte e ciência, filosofia e religião; e tece sempre mais fechada [dicht para que esqueçamos a solidão e a morte daqueles que amamos e de nós mesmos.”205

Este debate reenvia ao problema da entropia e das tentativas sísificas de superá-la ${ }^{206}$. Ao comunicar, é possível por alguns momentos acreditar que sempre estaremos aqui, que não há dissipação de energia no universo, que não há morte térmica e que não estamos todos condenados ao desaparecimento. Trata-se de um pensamento que reúne, aparentemente, preceitos da segunda lei da termodinâmica, da cibernética e do existencialismo. Mas não: embora os discursos sejam de certa

\footnotetext{
202 Ibid. Pág. 11.

${ }^{203}$ Ibid. Pág. 9.

${ }^{204}$ Idem.

205 Ibid. Pág. 10.

206 O tema entropia e comunicação foi detalhadamente tratado em nosso trabalho de mestrado "O eterno retorno na cibersociedade”. Eca-USP, 2000.
} 
forma afins, Flusser confirma seu vínculo com outras raízes do pensamento, enfim, com sua radicalidade nômade e nada eurocentrista. Palavras como "coisa", "nada", "ser", têm para ele - em cada uma das suas línguas mães - valor próprio e intransferível. Por isso, o pacto da comunicação com a metafísica, embora efetivo, não é tão assustador (unheimlich) quanto parece. Quando se pergunta "o que é comunicação", cai-se irremediavelmente nas tramas heideggerianas da pergunta pelo Ser. Ora, toda pergunta por algo é ontológica, busca com a sutileza da palavra "é" o total e o incorruptível, o eterno. Se pensarmos assim, Pouco restará da "tarefa do pensamento" neste tempo em que a filosofia se reduz às cadeias da linguagem. Pouco restará de esperança e de liberdade. Mesmo Nietzsche, tendo constatado no Zaratustra a morte de Deus, admite no Crepúsculo dos ídolos: "Receio não nos livrarmos de Deus, pois ainda cremos na gramática...” ${ }^{207}$ Mas para Vilém Flusser, estes ainda são temas demais europeus, enraizados como se fossem plantas, pátrios. Pode-se simplesmente olhar de um outro ângulo, de uma outra língua na qual o termo Sein é insuficiente. Neste momento, Flusser propõe que - para além do alemão de tom hegeliano - cada língua é em seu interior suficientemente filosófica:

A tradução da palavra Sein para o português revela radicalmente a dependência lingüística ontológica. A língua portuguesa analisa as diversas modalidades do Sein sem existencialismo, sem fenomenologia e sem a análise categorial de Hartmann. Heidegger, Jaspers, Sartre e Camus teriam talvez analisado o problema do Ser de uma forma radicalmente diferente se tivessem aprendido o português. A palavra Ser significa, aproximadamente, o Sosein dos existencialistas (ser-assim), a palavra estar representa o Dasein em largos traços, a palavra ficar abrange o Vorbandensein e o Zubandensein (serdiante-da-mão e ser-à-mão) e ultrapassa-os. O prédio fica do lado direito significa tanto a sua disponibilidade quanto a limitação que ele representa aos que estão na rua, isto é, para aqueles que são pedestres. A simples contraposição das três palavras neste contexto esclarece, de um golpe, a problemática do existencialismo e vale pela leitura de muitos temas de filosofia. ${ }^{208}$

\footnotetext{
${ }^{207}$ NIETZSCHE, Friedrich. Crepúsculo dos ídolos. "Sobre a razão na filosofia", \ 5.

${ }^{208}$ FLUSSER, Vilém. Lingua e realidade (1963). São Paulo: Annablume, 2004. Pág. 120.
} 
Desde os antigos já se sabe que a filosofia, antes das amarras metafísicas, está fundada no espanto. Mas isso se perdeu, diz Flusser, e o que existe agora é o tédio. E para ele não só o existencialismo, mas também a fenomenologia não conseguiu dar conta do problema:

Dada essa nossa situação [instrumental], compreendem-se as tentativas de uma reconquista do espanto, que são, no fundo, tentativas de dar significado à existência humana pela procura deliberada de uma segunda ingenuidade. É deste ângulo que devemos interpretar a fenomenologia husserliana, que é um método de deixar a coisa ser coisa. Pela "redução eidética", isto é, pela supressão de todos os conhecimentos a respeito da coisa, procura Husserl redescobrir a coisidade, o eidos da coisa, o espanto da coisa. E é deste ângulo que devemos interpretar o surrealismo, que é uma tentativa de ver a coisa com olho novo e redescobrir seu espanto. Mas, bem no fundo, são frustradas todas essas tentativas. A ingenuidade não é algo a ser procurado. Como a virgindade, não pode ser reconquistada. ${ }^{209}$

O homem não é mais capaz de se espantar, pois está jogado entre seus instrumentos. E instrumento não é coisa nenhuma, mas tão-somente "a coisa domesticada" 210 ; não é nem mágico nem misterioso. Com o avanço das técnicas no século XX, Flusser vê um mundo entupido, de poros bloqueados, um mundo que causa "nojo", plenamente instrumentalizado, à beira da náusea. Ao relembrar o Camus do Mito de Sísifo, ele diz: "Realmente é difícil compreender por que não nos matamos nesse mundo." 211 A única resposta ou consolo é que, enquanto o espanto da filosofia persistir, não há motivo para matar-se $\mathrm{e}^{212}$. Pois bem, sigamos o rio de Flusser: "Abramos novas aberturas e experimentemos novos espantos." 213

\footnotetext{
209 FLUSSER, Vilém. Da religiosidade: a literatura e o senso de realidade (1965). São Paulo: Escrituras, 2002. Pág. 95.

210 Ibid. Pág 94.

211 Idem.

${ }^{212}$ Ibid. Pág. 96.

${ }^{213}$ Ibid. Pág. 46.
} 


\section{VIVER SEM PELE}

E nem destaco minha pele da confluente escuridão. Um fim unânime concentra-se e pousa no ar. Hesitando.

Drummond $^{214}$

\section{1}

Viver sem pele não é o mesmo que viver sem superfície. Pois na vida sem pele toma parte uma outra superfície, chamada ferida aberta. Exposição do monstruoso, carne apenas. Imprópria para o olhar. Imprópria para consumo. Não há como deitar o olhar sobre esta carne. Ela não é mais da ordem do olho, mas de uma outra imagem. Daí os recursos metafísicos, que funcionam como vitrine de açougue: isolam o olhar de todos os sentidos, cheiro, textura, calor, e recriam uma visão possível, compartimentada, maquiada, iluminada, limpa, científica. Viver sem pele é viver na impossibilidade da comunicação. Sem nenhuma alteridade, sem nada que seja pátrio tampouco estrangeiro. Nesta vida, que é quase morte, a comunicação se extingue pelo excesso. Não há nenhum tipo de separação ou individuação, apenas perversão. Também não há comunhão, aquilo que se conhece como reencontro com o todo, nostalgia da reunificação. Nada disso. Viver sem pele é dar ao corpo (em resumo, à existência) a condição de brecha escancarada.

\section{2}

Falar contra o humanismo não é falar em favor da bestialidade ${ }^{215}$. Da mesma forma, ter restrições quanto ao conceito de alteridade não é falar em favor do indiferenciado. O mundo sem diferença é um mundo sem outrem, pré-humano, uterino. Mas como ter o outro em consideração sem tomar partido dos princípios ontológicos de indivíduo, ser, substância? Como estabelecer um outro e suas

\footnotetext{
214 "Dissolução". In Claro enigma, 1951.

215 Tal foi o alerta de Heidegger em sua "Carta sobre o Humanismo". Opus. cit. In Gesamtausgabe. Vol. 12. Pág. 346.
} 
fronteiras? Ou simplesmente não se estabelece, acolhe-se? Biologicamente, o homem ainda é um ser temporalmente orientado, de maneira irreversível, para o futuro e para uma morte térmica. Por este motivo, a cada momento ele já é um outro - e com relação a si mesmo. E isso já se sabe desde Heráclito. A fronteira não é apenas uma demarcação espacial, mas uma grande teia formada de tempos, acasos, sensações, estímulos, cultura; enfim, por elementos tanto milenares quanto instantâneos, por tudo o que atravessa um corpo em sua breve história. $\mathrm{Na}$ vida sem pele essa teia se desfaz, deixando em seu lugar fantasmas.

Phantásma é um dos nomes para imagem. Para os gregos, uma imagem poderia ser participante do inteligível, do mundo das idéias, um eidolon; ou ainda um eikon, isto é, uma cópia realizada no sensível, diretamente sob os olhos dos mortais; finalmente, um phantásma, sem parentesco com os modos anteriores, é a imagem gerada internamente, não precisa de olhos e sim de imaginação. Disso nos fala Marilena Chaui. Ao analisar os media contemporâneos, ela afirma que as comunicações se tornaram em grande parte fantásmicas. Os objetos ou fatos perdem todo referencial. Toma lugar uma sociedade gerada e alimentada pelo medo, por todo tipo de coerções, terror, uma sociedade que simula a presença do outro enquanto o aniquila. Por isso, diz a filósofa, é preciso diferenciar o fantasma das outras imagens:

Eidolon e eikon necessitam de um medium para reproduzir a forma de alguma coisa; o phantásma é presença imediata em nós da coisa-em-imagem, sem mediação; ou seja, entre a coisa e nós nada se interpõe. A segunda diferença: eidolon e eikeon estão referidos às imagens das coisas externas a nós; phantásma, às imagens que permanecem em nós depois da percepção das coisas externas. O phantásma é a imagem interior e justamente por isso nada se interpõe entre ela e nós. ${ }^{216}$

O outro não tem mais corpo nem pele. É uma imagem que prescinde de qualquer mediação. Paradoxalmente, ele se torna visível graças a pretensos meios de comunicação. Mais uma vez, falar contra os media não é falar em favor do imediato. Do lado da mediação, está por exemplo o conceito de esfera pública que, nos últimos

${ }^{216}$ CHAUI, Marilena. Simulacro e poder: uma análise da mídia. São Paulo: Fundação Perseu Abramo, 2006. Pág. 81. 
três séculos, tem se mostrado contraproducente, trabalhando quase sempre contra o que é efetivamente público. Do outro lado, no imediato, toda a tradição metafísica teísta, afirmando continuamente a existência de idéias inatas e de uma mente capaz de atingir integralmente a verdade, sem qualquer mediação da experiência. $O$ fantasma, por sua vez, não atua diretamente sobre nenhum desses pontos. Ele cria para si uma terceira dimensão, decididamente perversa: confunde o público com o privado e cria sujeitos, chamados ora emissores ora receptores, que se supõem atores da história. Sujeitos que sequer suspeitam serem eles mesmos fantasmas.

Marilena Chaui relaciona a onda de assombração mediática à ideologia da competência. $\mathrm{Na}$ medida em que os meios de comunicação são representantes diretos da dita "sociedade do conhecimento", fazem-se por direito portadores do conhecimento, mas não só: estão socialmente autorizados a escolher, decidir e difundir a melhor informação possível, o conteúdo civilizatório/domesticatório apropriado para seus destinatários. Devido à identidade entre poder e informação típica de tal sociedade, seu "discurso tem a forma de um discurso do conhecimento e em ambos está em ação a ideologia da competência." ${ }^{217}$ Mas em que consiste exatamente esta ideologia?

O discurso competente determina de antemão quem tem o direito de falar e quem deve ouvir, assim como predetermina os lugares e as circunstâncias em que é permitido falar e ouvir e, finalmente, define previamente a forma e o conteúdo do que deve ser dito e precisa ser ouvido. Essas distinções têm como fundamento uma distinção principal, aquela que divide socialmente os detentores de um saber ou de um conhecimento (científico, técnico, religioso, político, artístico), que podem falar e têm o direito de mandar e comandar, e os desprovidos de saber, que devem ouvir e obedecer. Em uma palavra, a ideologia da competência institui a divisão social entre os competentes, que sabem, e os incompetentes, que obedecem. ${ }^{218}$

Competente, portanto, é todo aquele que trabalha em favor da fantasmagoria geral, da transformação paulatina do humano em animal doméstico, caseiro. O

\footnotetext{
217 Ibid., pág. 77.

218 Idem.
} 
melhor reprodutor do discurso competente, diz Marilena Chauí, é o especialista. Personagem bastante presente nos meios abertos de comunicação: “O especialista competente é aquele que, no rádio, na TV, na revista, no jornal ou no multimídia, divulga saberes, falando das últimas descobertas da ciência ou nos ensinando, por exemplo, à maneira do resenhista, como escrever um livro ou um artigo." ${ }^{\text {,19 }}$ Mas não basta divulgar conhecimentos distantes, científicos, pois ele quer entrar na vida de cada um, opinar profundamente no que há de mais pessoal: “O especialista competente nos ensina a bem fazer sexo, jardinagem, culinária, educação das crianças, decoração da casa, a ter boas maneiras, a usar roupas apropriadas em horas e locais apropriados, como amar Jesus e ganhar o céu, meditação espiritual, como ter um corpo juvenil e saudável, como ganhar dinheiro e subir na vida." 220

Mas o principal especialista é mais do que um mero conselheiro cultural. Vem de uma refinada genealogia, híbrido de vários outros especialistas. É dele que vêm os juízos definitivos sobre os fatos, o destino mundial. É o detentor da última palavra - e por isso mesmo sua comunicação, apesar de dirigia a um público, serve somente à anulação da alteridade. Não importa o que outro pense ou sinta. Eis o verdadeiro competente: "aquele que explica e interpreta as notícias e os acontecimentos econômicos, sociais, políticos, culturais, religiosos e esportivos, aquele que devassa, eleva e rebaixa entrevistados, zomba, premia e pune calouros - em suma, o 'formador de opinião' e o 'comunicador'."221 Trata-se de um tipo de comunicação que nada comunica e que já não tem mais relação com os ideais iluministas ou com a "antiga ideologia burguesa, que realizava uma inculcação de valores e idéias." ${ }^{222}$ Ao contrário, é coercivo: "Dizendo-nos o que devemos pensar, sentir, falar e fazer, afirma que nada sabemos e seu poder se realiza como intimidação social e cultural." ${ }^{223}$ Graças a tais manifestações cada vez mais freqüentes de especialidade e competência, a vida perde aos poucos camadas epidérmicas. Os fantasmas predominam sobre as outras formas de imagem, usando-se delas para garantir sua soberania. As conseqüências são perceptíveis (visíveis?) não somente no campo dos media, mas na alteração do estatuto do conhecimento - o que implica numa reviravolta epistemológica sem precedentes.

\footnotetext{
219 Idem.

${ }^{220} \mathrm{Idem}$.

${ }^{221}$ Idem.

${ }^{222}$ Idem.

223 Idem.
} 


\section{3}

Portador da clarividência dos que vivem no limiar, Günther Anders adverte para o poder da imaginação. O homem não está mais à altura de seus aparatos, sentese diminuído diante deles, numa espécie de vergonha prometeica. É que o resultado dos projetos humanos costuma ser muito maior e mais assustador do que um dia se supôs. Nós produzimos inclusive imagens que não imaginamos; este é seu mote. Anders nasceu em 1902 e não só assistiu como acompanhou de perto os terrores de seu século. Depois disso, como continuar fazendo filosofia de gabinete? O deleite com autores clássicos, a leitura dos mestres gregos, uma tese sobre filosofia da música, tudo isso foi deixado para trás. A época assim o exigiu. Suas principais teses estão em dois volumes intitulados $O$ antiqüismo do homem, escritos e continuamente reescritos entre 1956 e 1986. Ali, o autor se apresenta como um "filósofo de ocasião", guiado pelas demandas de seu tempo e do mundo a sua volta: "Por filosofia de ocasião entendo algo como um cruzamento híbrido entre metafísica e jornalismo. Uma filosofia, de fato, que tenha por objeto nossa situação atual, ou seja, que tenha o mundo de hoje como matéria." ${ }^{224}$ Assim, segundo este autor, $O$ antiqüismo do homem não contém nem ensaios literários nem análises filosóficas à maneira acadêmica. $\mathrm{O}$ que há são exemplos que poderiam responder pela antiga expressão "ocasionalismo" [Okkasionalismus], formando uma filosofia possível, de ocasião [Gelegenheitsphilosophie]. Numa entrevista concedida em 1977, publicada sob o inquietante título "E se eu estiver desesperado, o que tenho a ver com isso?”, ele explica seu percurso:

Compreendo que meus textos filosóficos têm muito pouco a ver com o monstruoso corpus das filosofias anteriores. Minha atividade filosófica tem sido de um outro tipo. Nestes meus 75 anos de vida [idade com que Anders concedeu a entrevista], o mundo e a posição do homem no mundo mudou tão radicalmente, que fui obrigado a partir do próprio real [Wirklichkeit]. O caminho pelo pensamento dos filósofos dos últimos 25 séculos tornou-se não só inútil mas também absurdo, para não dizer imoral: com eles eu teria gasto muito tempo até conseguir exercer alguma influência sobre meus

\footnotetext{
${ }^{224}$ ANDERS, Günther. Die Antiquiertheit des Menschen 1: über die Seele im Zeitalter der zweiten industriellen Revolution. Munique: C. H. Beck, 2002. Pág. 8.
} 
contemporâneos. Não há como se contentar em interpretar a Ética a Nicômaco quando se acumulam pelo mundo ogivas nucleares. ${ }^{225}$

Seu ponto de partida, no entanto, não é o real dos metafísicos e sim um real mal-assombrado pelas conquistas técnicas. O mundo passa a ser diariamente entregue nas casas, seja sob a forma de pizzas ou informações mediáticas. Trata-se de um mundo-fantasma ${ }^{226}$, que acaba transformando seus habitantes igualmente em fantasmas. Ninguém está mais presente na própria vida, na própria história: "Não são meras imagens o que recebemos. Também não estamos efetivamente presentes diante do real [Wirklichkeit]."227 E não é suficiente perguntar se estamos mesmo ausentes:

A questão "somos ausentes ou presentes?" é inválida. Não pelo fato de a resposta "imagem" [Bild] (e com ela o "ausente") estar por si mesma subentendida; mas sim porque a peculiaridade dessa situação consumada por transferência consiste em sua ambigüidade ontológica; porque os acontecimentos transmitidos são simultaneamente presentes $e$ ausentes, efetivos $e$ aparentes, simultaneamente aqui $e$ não aqui, enfim: porque são fantasmas. ${ }^{228}$

O que Anders chama de "situação consumada" diz respeito à capacidade destrutiva de objetos inicialmente concebidos com fins benéficos, à nova relação do homem com os acontecimentos ("os acontecimentos vêm a nós, não nós a eles."229), relação esta quase sempre unilateral, sem qualquer resquício dialógico. Deste processo resulta um canibalismo pós-civilizatório ${ }^{230}$, em que cada humano é um potencial produto, pronto a ser consumido e a pedir com veemência: "o nosso devorador de cada dia nos dai hoje." ${ }^{231}$ Nesta direção, o homem se equivaleria aos jornais nas bancas de revista, às latas de sopa, aos pacotinhos de batata frita, todos clamando do alto de suas prateleiras por alguém que os consuma.

225 ANDERS, Günther. Wenn ich verzweifelt bin, was gebt's mich an? (1977). Frankfurt: Campus, 1989. Tradução francesa consultada: Et si je suis désésperé que voulez-vous que j’y fasse? Paris: Allia, 2001. Pág. 74.

${ }^{226}$ ANDERS. Die Antiquiertheit des Menschen 1. Opus cit. Pág. 131.

${ }^{227}$ Idem.

${ }^{228}$ Idem.

${ }^{229}$ Ibid., pág. 110.

${ }^{230}$ Ibid., pág. 25.

231 Ibid., pág. 15. 
Não só o humano é algo ultrapassado, mas também o sentido. No segundo volume de $O$ antiquismo do homem, Günther Anders declara a morte do sentido. Tal é a razão de tantas próteses, suplementos sem sentido que visam emprestar sentido à vida. Essas próteses são encaradas por seus usuários com a última tábua de salvação. No contexto da primeira revolução industrial, o sentido estava em grande parte no trabalho - manifesto como exploração da mão-de-obra e roubo do tempo livre. Em verdade, o sentido da vida sempre esteve ligado a um absurdo aprisionamento de seus atores. Por isso, diz Anders, "falta de sentido é sintoma de saúde; e não o contrário." 232 Nos países pós-industriais mais ocidentalizados, sem as respostas do antigo mundo do trabalho, outros elementos se encarregam de trazer sentido - e, portanto, de prejudicar a saúde de seus indivíduos. Da religião ao café, tudo vale. O importante é não deixar brecha para o vazio, para o borror vacui. $\mathrm{O}$ autor cita o hobby como fonte de alívio aos mais ansiosos, que dizem: "Ah, se eu não tivesse minha coleção de selos!" 233 Nesta atividade que deveria, em princípio ser um meio de lazer, há uma enorme transferência libidinal vinda do mundo do trabalho, diz Anders. Hobby ainda é trabalho ${ }^{234}$.

É interessante observar que o bobby, artifício para dar sentido à vida, está muito mais presente em países anglo-saxônicos, como Alemanha e Inglaterra, do que em países do hemisfério sul. Nenhum outro povo, segundo Anders, leva a cabo tantas atividades sistemáticas a título de lazer do que os alemães. (Sob esta ótica, o brasileiro não teria hobbies e sim prazeres sazonais: a novela das oito, a cerveja no final do expediente, o futebol do fim de semana, o carnaval em cada fevereiro. Por mais refinadas que possam ser algumas dessas atividades, não se tratam de empreendimentos sistemáticos para os quais é preciso dedicar, além de tempo, um trabalho que envolve quase sempre categorização, ordenação e disciplina, compra de materiais especiais em lojas especializadas e consulta a catálogos. Para seus hábitos de lazer, o brasileiro geralmente improvisa o material, recolhe peças aqui e acolá, monta o time de futebol dos sem-camisa. Por seu turno, o bobbie, fazendo jus à raiz anglosaxônica, permite pouca ou nenhuma improvisação.)

232 ANDERS. Die Antiquiertheit des Menschen 2: über die Zerstörung des Lebens im Zeitalter der dritten industriellen Revolution. Munique: C. H. Beck, 2002. Pág. 370.

233 Ibid., pág. 373.

${ }^{234}$ Idem. 
Anders decreta antiquados o sentido, a aparência, o trabalho, a massa, a fronteira, a liberdade, a fantasia, a maldade e mesmo a morte. O problema agora se dá no campo da imaginação. Não há mais percepção nos termos da fenomenologia. Para perceber é preciso antes imaginar: "Nos dias de hoje, a percepção se chama imaginação. ${ }^{, 235}$ Esta sim deve ser cultivada, pois percepção fenomenológica, razão e projeto não dão mais conta dos assombros que o real nos apresenta:

Nosso primeiro postulado deve ser: amplie os limites de sua imaginação para saber o que você faz. Isso é inclusive necessário, pois nossa percepção não está à altura do que produzimos: como tinham ar inofensivo aquelas garrafinhas de Zyklon B - eu as vi em Auschwitz - com as quais foram suprimidas milhões de pessoas! E um reator atômico, como tem ar benevolente com seu teto em forma de cúpula! Mesmo se, sozinha, a imaginação é insuficiente, acionada de maneira consciente ela alcança [nimmt] infinitamente mais verdade [mehr 'wahr"] do que a percepção [Wahr-nehmung]. Para estar à altura do empírico, justamente, e por mais paradoxal que possa parecer, é preciso mobilizar nossa imaginação. É ela a "percepção" de hoje. ${ }^{236}$

\section{4}

A teia epidérmica desaparece - assim como desapareceu para Walter Benjamin a aura: trama singular de tempo e espaço, aparição única de um distante, por mais próximo que seja ${ }^{237}$. Só tem aura aquilo que é único, que transpira vida, que pede para ser, que transborda de si mesmo. Não pode haver aura num mundo que não é sequer pelado - mas despelado. É nos objetos da cultura que se vê com mais nitidez, em primeiro plano, essa falta de pele - ou aura. Benjamin foi perspicaz em seu diagnóstico sobre a reprodutibilidade técnica da obra de arte. Se esta perde a aura, é porque seu fundo também não está mais lá. E não se trata da perda de um fundo metafísico, mas do pressuposto de qualquer manifestação viva: um corpo.

235 ANDERS. Et si je suis désésperé que voulez-vous que j’y fasse? Opus cit. Pág. 66.

236 Idem.

237 BENJAMIN, Walter. "Das Kunstwerk im Zeitalter seiner technischen Reproduzierbarkeit". In Schriften. Vol. I, 2. Frankfurt: Suhrkamp, 1974. Pág. 712. 
A reprodutibilidade técnica foi, aos olhos de Benjamin, algo assustador, terrífico, unheimlich. Poucas décadas depois da publicação de seu texto, tornou-se possível reproduzir tecnicamente não apenas objetos de arte mas também seres vivos, mamíferos, incluindo o ser humano. $\mathrm{O}$ que será pior? $\mathrm{O}$ terror da aniquilação em massa ou a vertigem a reprodução em série? Benjamin teve de lidar com o fato de que, em seu tempo, as obras eram reproduzidas na mesma velocidade e competência com que vidas eram extintas aos milhões. A técnica multiplicou não só as obras de arte, mas também a morte: “Em vez de canalizar os cursos d'água, ela [a técnica] enche trincheiras com enxurradas humanas. Em vez de fecundar a terra do alto de seus aviões, ela semeia o incêndio. E em seus laboratórios químicos, encontrou um procedimento novo e imediato para suprimir a aura." 238 Isso trouxe uma dialética até então inédita entre o próximo e o distante, que somente a teoria benjaminiana da aura soube responder. Mas sem trazer alívio para o terror.

Uma saída momentânea talvez seja ainda o labirinto, ou melhor, as passagens labirínticas da cidade. Benjamin nos mostra que há certamente na cidade outras vocações ou sentidos além dos consolidados na Política aristotélica. Já com Ulisses aprendemos que Ítaca são várias, caminha no tempo, e por isso não há reencontro possível com a cidade mãe, com a Ítaca que se deixou para trás antes da viagem ${ }^{239}$. As cidades viajam tanto quanto nós, são como o rio de Heráclito. Nada mais exemplar neste sentido do que cidade do flâneur, nem plana nem profunda, mas labiríntica, feita de entranhas, assim como de disfarces, luzes, vitrines. Cidade matriz, nela circulam Teseus e Ariadnes e fios de todos os tempos se embaraçam, tecem novos sentidos. Para Walter Benjamin, a cidade é por excelência o lugar das passagens, de vida autogeradora, plena de poros que parecem expelir continuamente os sintomas da época. A rua, nem sempre ódos ou via linear, reproduz caminhos e dobras de uma outra cidade, ancestral, pré-política:

\footnotetext{
238 Ibid., pág. 738.

239 Sobre isso ver o texto de Olgária Matos "Ulisses e a razão insuficiente" (In O iluminismo visionário. São Paulo: Brasiliense, 1993), em especial, o seguinte trecho: "A nostalgia de Ulisses é o sentimento de quem não tem morada; em nenhuma parte de si mesmo encontra repouso. /.../ Para Ulisses, Ítaca é o centro do mundo, seu eixo arquimediano, o ponto fixo. Porém, o repatriado não encontra em sua pátria aquilo que procurava, não reconhece seu 'lugar natural'. Quando volta, ele mesmo está mudado e Ítaca não permanecera tampouco a mesma. /... / A terra natal transforma-se em terra estranha, por uma dialética sutil do espaço e do tempo. Ulisses reencontrará pois sua Ítaca lá mesmo onde havia deixado, mas o Ulisses de outrora, aquele que deixou sua ilha, ele não reencontrará mais. Ulisses é agora outro Ulisses que reencontra outra Penélope. E Ítaca é também uma outra ilha.” Pág. 172.
} 
A rua conduz o flanador a um tempo desaparecido. Para ele, todas são íngremes. Conduzem para baixo, se não para as mães, para um passado que pode ser tanto mais enfeitiçante na medida em que não é o seu próprio, o particular. Contudo, este permanece sempre o tempo de uma infância. Mas por que o de sua vida vivida? No asfalto sobre o qual caminha, seus passos despertam uma surpreendente ressonância. O lampião a gás que resplandece sobre o calçamento projeta uma luz ambígua sobre esse fundo duplo. ${ }^{240}$

Ruas que "conduzem para baixo" são em Benjamin o sinal de uma cidade uterina. A viagem é solitária e muda pois, de fato, "a cidade é a realização do antigo sonho humano do labirinto" e "o flâneur, sem o saber, persegue essa realidade." 241 Ele imprime na caminhada um ritmo próprio, uma pisada que com-passa suas observações. Rostos, gestos, imagens superpostas estão na ordem do seu dia. E têm aura. Não é apenas a luz do sol que dá os tons: graças aos lampiões a gás do tempo de Baudelaire ou às novas lâmpadas elétricas, sombras aparecem. São assombrações, aparições sobre um fundo que, como sugere Benjamin, é "duplo". Fundo superficial, do qual o que se conhece é o avesso.

Esta cidade não tem cidadãos; o próprio flanador é um eterno estrangeiro que, para se desviar de ser decifrado, aprimora seus disfarces. $\mathrm{Na}$ urbe uterina, infinita e sem saída, a única coisa que lhe importa são as passagens. Se sente fome, "não quer saber das mil e uma formas de aplacá-la." ${ }^{242}$ Lojas, mulheres e bistrôs o seduzem, mas sem promessa de saciedade. Ao contrário do Ulisses mitológico, o flâneur não tem esperanças de reencontro. É nutrido pelo sentimento de permanente inquietude e despaisamento (Unheimlichkeit). "Como um animal ascético, vagueia através de bairros desconhecidos até que, no mais profundo esgotamento, afunda em seu quarto, que o recebe estranho e frio." ${ }^{243}$ Viajante de um oceano urbano, o flâneur traz os traços e assombros de seu século:

\footnotetext{
240 BENJAMIN, Walter. “O flâneur”. In: Obras escolbidas III. São Paulo: Brasiliense, 1989. Pág. 185.

241 Ibid. Pág. 203.

242 Ibid. Pág. 186.

${ }^{243}$ Idem.
} 
O século não soube responder às novas virtualidades técnicas através uma nova ordem social. Eis o porquê de a última palavra ter ficado nas passagens perturbadoras do antigo e do novo, que estão no âmago de suas fantasmagorias. O mundo dominado por suas fantasmagorias é - servindo-se da expressão de Baudelaire - a modernidade. ${ }^{244}$

Ali, as comunicações também se tornam fantasmagóricas. Não convivem pacificamente, seu motor é a guerra e o mutismo. Benjamin se ocupa deste conflito assim como fizera Victor Hugo no romance Notre Dame de Paris quando, numa célebre digressão, lamenta a violenta substituição da escrita da pedra, linguagem sublime da Catedral, pela nova tecnologia da imprensa. Em "O narrador" ${ }^{245}$ são avaliadas e praticamente descartadas as possibilidades narrativas no século das duas grandes guerras. Um homem ao voltar da guerra, diz Benjamin, está mudo, não tem nada a contar. O problema se acentua quando as novas técnicas de informação, sobretudo do jornal e das notícias, impõem um novo ethos. As comunicações competem entre si. ${ }^{246} \mathrm{E}$ pior: não asseguram o bem-estar prometido.

\section{5}

"Sou todas as comunicações, como posso ser triste?"247

\section{6}

O melancólico é um suicida potencial. Se bem que sua experiência de intimidade com a morte parece estar além desse gesto último, ou melhor, num aquém inacessível ao outro, em seu cotidiano mais que solitário. Se há os melancólicos que

\footnotetext{
244 Derpassagenwerk. In: Gesammelte Schriften. Frankfurt am Main: Suhrkamp, 2000.

245 BENJAMIN. „Der Erzähler“, 1936. In Medienästhetische Schriften. Frankfurt am Main: Suhrkamp, 2002. 246 "Há uma rivalidade entre as diversas formas de comunicação. Na substituição da antiga forma narrativa pela informação, e da informação pela sensação reflete-se a crescente atrofia da experiência. Todas essas formas, por sua vez, se distinguem da narração, que é uma das mais antigas formas de comunicação. Esta não tem a pretensão de transmitir um acontecimento, pura e simplesmente (como a informação o faz); integra-o à vida do narrador, para passá-lo aos ouvintes como experiência. Nela ficam impressas as marcas do narrador como os vestígios das mãos do oleiro no vaso da argila." In: "Sobre alguns temas em Baudelaire”. Benjamin. Obras escolhidas III. São Paulo: Brasiliense, 1989. Pág. 107.

${ }^{247}$ DRUMMOND. "Os últimos dias", in A rosa do povo, 1945.
} 
aprendem a viver, não se tem notícia. Eles não deixam rastros. Seu aprendizado inclui silêncio e recolhimento - sem que haja contudo um desvencilhamento da idéia de morte, pois esta continua paradoxalmente sendo sua condição de vida. Também não se arquitetam fórmulas de sobrevivência: a estratégia, se considerada como instrumento de controle ou previsibilidade, está longe de constituir o universo do melancólico; as estratégias da melancolia, se existirem, serão sobretudo de natureza subterrânea, nascidas na obscuridade, muitas vezes na impossibilidade mesma do pensamento.

Habitante de um mundo negativo, o melancólico é principalmente um rebelde. Em silêncio, recusa-se a participar do excesso, do comunicativo, do abundante. Seu apreço por pequenices, miniaturas, coleções de objetos inúteis e bizarros faz parte de um quadro não só mórbido, como muitos especialistas insistem em diagnosticar. Trata-se, antes, de contundente crítica à tagarelice, à apologia da palavra explícita e de repúdio a uma sociedade em que tudo precisa ser exaustivamente dito com todas as letras e exibido sob todos os ângulos. Rebeldia avessa, pois alimentada na delicadeza.

Numa época reconhecidamente adoecida das imagens, torna-se difícil localizar o melancólico, já que ele parece ter aprendido estratégias de invisibilidade, mesmo de incomunicabilidade. Ele sabe trocar de pele. Situação irônica, se considerarmos que já há bastante tempo a melancolia foi apresentada como mal das imagens. Na doutrina hipocrática dos quatro humores, devido ao desequilíbrio na secreção da bílis negra (Mélas kbolè) no sangue, o indivíduo torna-se quase ausente, lento e sobretudo imaginativo, recolhido num mundo de formas por ele próprio criadas. Mas ali, para os gregos, a melancolia ainda não era considerada doença; constituía uma compleição entre outras. Podia-se, por natureza, ser melancólico, colérico, sangüíneo ou fleumático. Dizia-se até que a bílis negra determinava os grandes homens, as personalidades de exceção. ${ }^{248}$

Foi o período medieval que fez da melancolia o mais condenável entre os pecados capitais, a preguiça, responsável por abrigar pensamentos impróprios num

\footnotetext{
${ }^{248}$ Julia KRISTEVA, em Soleil noir, dépression et mélancolie, cita a obra atribuída a Aristóteles Problemata (30, I), que faz elogio ao melancólico. A autora diz: "Avec Aristote, la mélancolie, équilibrée para le génie, est coextensive à l'inquiétude de l'homme dans l'Être. On a pu y voir l'annonce de l'angoisse heideggerienne comme Stimmung de la pensée. Schelling y découvrait, de manière similaire, l'essence de la liberté humaine." Pág. 16-17.
} 
corpo tomado pela akédia ${ }^{249}$. O caráter doentio, entretanto, só foi reforçado tempos mais tarde. No texto "Imagens sem objeto", Olgária Matos apresenta o tema, lembrando que:

A partir do Renascimento, a melancolia torna-se a mais temida de todas as doenças, por uma peculiaridade: é, segundo Marcilio de Ficino, uma doença da imaginação. Os delírios melancólicos são os mais cruéis e ultrapassam em intensidade as dores físicas, porque todo sofrimento é sentido pela alma, e aumenta quando o agente a toca diretamente, sem a intermediação do corpo. Não constituindo mais uma "blindagem", a alma fica entregue ao delírio. ${ }^{250}$

Com isso não é difícil entender os desdobramentos subseqüentes. $\mathrm{Na}$ modernidade da cisão e do mecanicismo, a luz da razão se contrapõe à obscuridade imaginativa do melancólico. O cogito cartesiano é bastante representativo neste sentido, pois inaugura a consciência de que o homem está separado da natureza, sendo o trauma desta separação motivo de luto. O mundo moderno, primando pela relação do sujeito (subjectum) com seus objetos (objectum, o que se coloca diante do sujeito), não permite lugar para os que vivem simplesmente da fissura (e não da relação, como se espera). Daí também o melancólico ser um habitante da fronteira.

Freud descreve tal fenômeno como fruto de uma perda irreparável que culmina num luto que não se deixa trabalhar ${ }^{251}$. Mas ele próprio sinaliza que pode não ser só isso: "A melancolia, como já vimos, tem algo a mais que o luto normal. Nela, a relação com o objeto não é uma relação simples, pois se complica pelo conflito de ambivalência"252 O texto diz ainda que na melancolia "trama-se uma multidão de combates pelo objeto, nos quais ódio e amor lutam um com o outro: o ódio para arrancar a libido do objeto, o amor para afirmar essa posição da libido contra o ataque. ${ }^{253}$ Freud admite que resta algo de inexplicável, pois não se sabe onde fica a linha a separar a vida e o luto, o objeto e sua desaparição. E não se sabe

\footnotetext{
${ }^{249} \mathrm{Na}$ etimologia desta palavra grega está o "cadáver insepulto".

${ }^{250}$ MATOS, Olgária C. F. "Imagens sem objeto". In: NOVAES, Adauto (org.). Rede imaginária: televisão e democracia. São Paulo: Companhia das Letras, 1991. Pág. 18.

251 FREUD, Sigmund. Trauer und Melancholie (1917e). Studienausgabe, t. III. Tradução francesa consultada de Jean Laplanche, Oeuvres complètes de Freud, vol. XIII, pág. 261-178. Paris: PUF, 1988.

252 Ibidem, pág. 276.

${ }^{253}$ Idem.
} 
também, ele diz, por que o luto de alguns dura mais do que o de outros e porque algumas pessoas sentem-se melancólicas apenas por algumas horas ou dias, enquanto outras têm na melancolia a condição de toda a vida. Mas Freud não toca na questão da mistura.

Se o melancólico mistura-se aos objetos num apreço silencioso, é porque sua intimidade com o mundo não é delineada, mas sim de borramento. E, se houve uma perda, ela também não se classifica. Afinal, o que se perdeu? Deus, o uno, o pai, o sentido, o signo, a potência de existir? E o que são todos esses substantivos se não abstrações? Tal cadeia de perguntas, por enquanto, leva a crer que a questão pode ser discutida não só nos termos do sujeito e do objeto, mas também do que está entre eles, a fronteira. É lá que se dá a experiência limite, a abolição das identidades; lugar tanto da aporia como da passagem. Jacques Derrida - citando a entrada/passagem heróica de Édipo em Tebas - diz que no fundo essa é a experiência da morte, portanto incomunicável e impassável:

O que é então atravessar essa fronteira do último? O que é passar ao termo de uma vida (terma tou biou)? É possível? Quem já o fez? Quem pode testemunhá-lo? O "eu entro", o passar pelo limiar, o "eu passo (perâे) nos coloca, se assim posso dizer, sobre a via do áporos ou da aporia: o difícil ou o impraticável, aqui passagem impossível, recusada, denegada ou proibida, ou seja, o que pode ainda ser outra coisa, a não-passagem, um acontecimento advindo ou a vir que não tem mais forma ou movimento consistente a passar, atravessar, transitar, o "passar-se" de um evento que não teria mais a forma ou o andar do passo: em suma, uma chegada sem passo. ${ }^{254}$

Possivelmente por essa perplexidade diante da fronteira que não se deixa transpor e muito menos dominar, o homem torna-se o único animal a engendrar passagens extraordinárias. Sabendo-se finito, liga a morte à palavra (logos) e à memória; toma contado com a aporia por excelência que é experimentar a finitude. E aqui não é demais lembrar, juntamente com Derrida, que este é o mote da cultura (ou de todas as culturas). Se a expressão "cultura da morte" soa como pleonasmo ou

${ }^{254}$ DERRIDA, Jacques. Apories - s'attendre aux limites de la vérité. Paris: Galilée, 1996. Pág. 25. 
tautologia, é para oferecer a leitura de que cada cultura trata a morte de modo distinto $^{255}$. Mas até agora nada se compara ao Ocidente, que fez dela seu sinônimo: ocaso, declínio, desaparecimento na escuridão. Não é de espantar portanto que as passagens que o Ocidente abre para si, como consolo à finitude, sejam passagens luminosas, constituídas ora sob as luzes do esclarecimento ora sob os lampejos da imaginação.

Habitante da fronteira, o melancólico recusa as passagens já constituídas, ordinárias. Ele busca sozinho suas Holzwege $e^{256}$, clareiras, caminhos inusitados pela floresta. Por conhecer de tão perto a aporia, é capaz de encontrar os poros inéditos que garantem sobrevivência em meio às ofertas cansativas da ideologia do trabalho e da atividade. Neste ponto, a depressão como patologia marcante do século XX estaria ligada à aporia melancólica, a um ver-se sem saída numa sociedade que exalta o excesso - de consumo, de propriedade, de telas, de holofotes, de imagens. Sociedade da bybris (descomedimento), da obsessão pelo ver e pela ver-dade. Vai-se longe demais, apenas para ver onde tudo vai dar.

E o nosso tempo já fez ver muito. Sofre-se do mal de imagens, mas não das imagens melancólicas, pois estas são endógenas, geradas sangüineamente para alimentar um ciclo existencial solitário e servem, no limite, como objetos de diálogo e distração. São de natureza completamente oposta àquelas que se impõem como única realidade possível no século XXI, geradas exteriormente para suprir a falta de imaginação. Aqui, o problema não é de perda, mas novamente de saturação. Derrida, como filósofo do dom, diz que não se sabe (ou não se quer) administrar todo o possuído, o recebido, enfim, o que é de nossa propriedade. Pois o primeiro desses dons já é demais agressivo: ter recebido um nome é um ferimento sem nome ${ }^{257}$. E a ferida aumenta na medida em que se acumulam as imagens, herdadas uma a uma, juntamente com o nome.

255 Ibid., pág. 83.

256 O tema da clareira (Lichtung) é recorrente em Heidegger e dá origem por exemplo ao seu livro Hol乏wege, traduzido para o francês como Chemins qui ne mènent nulle part, Paris: Gallimard, 1962.

${ }^{257}$ Em L'animal que donc je suis (1999), Derrida fala do silêncio do que é nomeado, inclusive o homem: "A tristeza, o luto, a melancolia (Traurigkeit) da natureza ou da animalidade nasceriam assim, segundo Benjamin, desse mutismo, é certo (Stummbeit, Sprachlosigkeit), mas também, por isso mesmo, deste ferimento sem nome: ter recebido o nome. (Como se o homem não recebesse também seu nome e seus nomes!)”. Pág. 41 da edição brasileira: O animal que logo sou. São Paulo: Unesp, 2002. 
Ora, as imagens só imaginam, não iluminam. Esta parece ser uma chave para entrever o simulacro do que se conhece como sociedade da informação ${ }^{258}$. Não há mais nenhuma luz, nenhum conhecimento possível de si nem do mundo. Olgária Matos fala do lugar central ocupado pelas imagens no fim do século XX, mas diga-se "central entre aspas, porque se trata de um mundo de imagens, quer dizer, contrariamente à luz da construção platônica e cartesiana do conhecimento, sem centro, sem ponto fixo, inconstante, impermanente." ${ }^{259}$ Isso nos reenvia a um tipo muito especial de melancolia, a de um humano sobrevivente à técnica e aos espetáculos de destruição que tornaram tudo público e publicitário, inclusive a morte.

A sociedade dos media é também a do médio, isso já sabemos. O indivíduo mediático mora em sua própria casa, em busca da permanência, enredado em retângulos e visões do distante, em tele-visões. E vai contra aquela sabedoria obscura que diz que o mais próprio do homem é o que está fora dele, fora da casa, do comum. Ou ainda: que a morada do homem é o movimento, o fluxo do rio, o sempre outro. Os gregos pré-socráticos entendiam que o homem nasceu para habitar próximo aos deuses. A esta morada - morada excelente - era dado o nome de ethos, mesma palavra originou o que hoje conhecemos como ética. O termo também denotava o caráter, a peculiaridade daquele que distingue-se de todos os outros seres sobre a Terra. Assim, o fragmento 119 de Heráclito diz "A morada do homem, o extraordinário" ( $\square \square \square \square \square \square \square \square \square \pi \square \square \cdot \square \square \square \square \square \square{ }^{260}$ ), isto é, o caráter do homem é o divino ou genial (daímon), aquilo que foge do comum é, enfim, a excelência. Além do mais, somente o ser humano "mora" - outros animais podem ter abrigo mas não têm ethos.

Daímon é o gênio que acompanha o homem. E cada um tem o daimon que merece: o de Sócrates, por exemplo, soprou-lhe aos ouvidos “Exercita a música!"; o de Descartes era um malin génie; o dos homens de hoje parece estar silenciado. Para os gregos, ter um bom daimon era o mesmo que ser feliz. Perdê-lo, ou recusar-se a escutá-lo, era uma condenação ao infortúnio. Heráclito nos deixa esse rastro no

\footnotetext{
258 Aqui é inevitável lembrar Dietmar Kamper: "estar informado é, literalmente, estar nas imagens". O trocadilho é feito com o substantivo Bild (imagem) e o verbo bilden, de significado amplo e que é traduzido geralmente por formar, ou seja, colocar de acordo com a forma, também educar.

${ }^{259}$ MATOS, Olgária. Opus cit. Pág. 15.

260 A tradução "A morada (Heim) do homem, o extra-ordinário (Unheimliche)" é de Emmanuel Carneiro Leão, discípulo brasileiro de Heidegger. Outras traduções consultadas: José Cavalcante de Souza, Os pensadores: "O ético no homem é o demônio"; Jean Bolack: "Les caractères de l'homme, le dieu".
} 
escuro: o ser do homem é aquilo que ele não é, forças de ultrapassamento, fascinação pelo desconhecido. No mundo dos media e das imagens que não imaginam, contudo, seu ser é apenas o visto, o mediano, o comunicável. O extraordinário perdeu-se e a morada tornou-se comum, isto é, lugar onde se foge de si mesmo e de seu daímon.

Talvez seja por isso que o melancólico, sobretudo em nosso tempo, tende a sentir-se deslocado, sem solo, despaisado. Confunde-se com a figura benjaminiana do flâneur, que faz da cidade inteira sua casa e zomba em silêncio dos amores de vitrine. Se viveu uma perda, se rompeu com o absoluto, se é um ateu, isso são ainda clichês; o melancólico não se deixa capturar por nenhuma lente sem estar devidamente disfarçado. Também não é de se dizer com facilidade: ficou órfão da palavra. Muitas vezes privado da potência de existir, vagando pelas ruas como um cadáver insepulto, retira sem saber de onde a energia extrema da aniquilação. E desaparece em meio ao labirinto de ruas e luzes.

Mas o mistério dessa energia permanece. Benjamin toca marginalmente neste tema, quando fala, por exemplo, de um certo caráter destrutivo, de uma espécie de iconoclasta da cultura, alguém que atira sem alvo apenas para nos lembrar que as coisas/imagens são levadas muito a sério. Esse tipo é o sobrevivente aos males de imagem. É bem possível existirem muitos deles circulando entre nós - e que nós mesmos os percebamos tacitamente, pois não temos coragem nem palavras para trazermos à tona sua natureza. A força em negativo, acompanhada da incorrigível estrangeiridade e da imaginação endógena, parece garantir o viver do melancólico. Destruir, assim como nos diz Benjamin, seria a fonte para reconquistar a leveza necessária à existência: "O caráter destrutivo não vive do sentimento de que a vida não vale a pena ser vivida, e sim de que o suicídio não compensa."261

\section{7}

No caminho destas porografias está Georges Bataille que, à margem da filosofia francesa do pós-guerra, pensou a comunicação como dissolução e passagem, numa perspectiva que o aproxima de Nietzsche e lhe dá os subsídios para a

\footnotetext{
261 BENJAMIN, Walter. "Der destruktive Character". In: Gesammelte Schriften, IV, p. 396-398. Tradução brasileira em volume organizado por Willi Bolle: "O cartáter destrutivo”, In: Documentos de cultura, documentos de barbárie. São Paulo: Cultrix, 1986.
} 
constituir, juntamente com Maurice Blanchot e outros contemporâneos, o que ele chama na revista Acéphale de "comunidade daqueles que não têm comunidade". Certamente seu discurso está bem longe de uma elaboração a partir de idéias claras e distintas; ao contrário: funda-se no uso dos aforismos, das sugestões, das citações obscuras de pensadores igualmente obscuros. Por isso, não é o caso aqui de esclarecer Bataille, tampouco de explicá-lo - pensar com ele parece a única maneira de entrar em seus textos privilegiando as vias interpretativas por ele mesmo apontadas. Entre seus escritos teóricos, $A$ experiência interior é o livro que apresenta de maneira mais incisiva a prioridade da comunicação no pensamento e na vida. Para comunicar o incomunicável da experiência interior é preciso, diz ele, ainda alguma distância, alguma alteridade. Neste sentido, a idéia de si é cuidadosamente considerada: “Si mesmo’ não é o sujeito isolado do mundo, mas um lugar de comunicação, de fusão do sujeito e do objeto."262 Claro que o que se pretende comunicar a partir do si não é o projeto de um homem e sua razão, mas sim a contestação e o êxtase:

Poderia dizer a mim mesmo: o valor, a autoridade, é o êxtase; a experiência interior é o êxtase; o êxtase é, aparentemente, a comunicação, oponde-se ao achatamento sobre si. [...] Mas nada resiste à contestação do saber, e vi, no fim, que a própria idéia de comunicação nos deixa nus, não sabendo nada. ${ }^{263}$

$\mathrm{Nu}$, não sabendo nada: a situação aterrorizante da nudez é o que prepara, por outro lado, o êxtase, a vida no limite, a pele como única fronteira para um si disposto a lançar-se. À primeira vista, Bataille permanece no lado niilista dos pólos interiorexterior, sujeito-objeto e êxtase-projeto. Mas apostar neste argumento seria precoce demais. Há de se considerar que para este autor a comunicação implica distância. Não é o mesmo que comunhão, pois nesta os elementos se fundem definitivamente, não havendo mais separação em nenhum grau, apenas o silêncio do indiferenciado, caos primordial. Quando fala em experiência interior, fala principalmente de um conjunto de apreensões sensoriais e históricas que formam uma sutil fronteira em torno do vivente. Daí a invalidade dos discursos racionalistas para sua filosofia:

\footnotetext{
262 BATAILLE, Georges. A experiência interior (1943-1954). São Paulo: Ática, 1992. Pág. 20.

${ }^{263}$ Idem.
} 
A experiência interior, não podendo ter princípio em nem em um dogma (atitude moral), nem na ciência (o saber não pode ser o seu fim ou a sua origem), nem em uma procura de estados enriquecedores (atitude estética, experimental), não pode ter outra preocupação nem outro fim senão ela própria. Abrindo-me à experiência interior, estabeleci, desta maneira, o seu valor, a sua autoridade. ${ }^{264}$

Justamente por seu conteúdo extático, a experiência interior encontra-se na fronteira da linguagem. Sobre ela, Bataille propõe tão-somente um esboço conceitual, rejeitando a tentação da imobilidade teórica. "Também não gosto das definições estreitas ${ }^{265}$, diz ele. A interioridade do experimentado, se tiver um alvo, não se encontra na ciência, mas no vivido - o que, no limite, opera a fusão entre existência e epistemologia: "A experiência interior responde à necessidade em que me encontro e comigo a existência humana - de colocar tudo em jogo (em questão), sem repouso admissível." ${ }^{266}$ Neste sentido, a experiência interior opõe-se radicalmente à idéia de um sujeito isolado que age dominantemente sobre os objetos. Trata-se, antes, da ruptura destes conceitos a partir de suas próprias instâncias: "A experiência atinge, para terminar, a fusão do objeto e do sujeito, sendo, como sujeito, não-saber e, como objeto, o desconhecido. ${ }^{267}$ Mas esta seria a primeira fase de um projeto de amplitude epistemológica visando, paradoxalmente, acabar com o projeto. É nesta direção que Georges Bataille aponta a supressão do sujeito e do objeto como "único meio de não chegar à possessão do objeto pelo sujeito, quer dizer, de evitar a absurda corrida do ipse querendo ser tudo." 268

A questão agora é: num cenário em que sujeito e objeto estão abolidos, como é possível ainda comunicar? Que tipo de distância subsiste? Poeticamente, a pista é dada no seguinte trecho:

\footnotetext{
${ }^{264}$ Ibid., pág. 14.

265 Ibid., pág. 11.

266 Idem.

${ }^{267}$ Ibid., pág. 17.

268 Ibid., pág. 59.
} 
Não há mais sujeito-objeto, mas 'brecha escancarada' entre um e outro e, na brecha, o sujeito e o objeto são dissolvidos, há passagem, comunicação, mas não de um a outro; um e outro perderam a existência distinta. ${ }^{269}$

Assim, o que assegura o comunicar é a própria ruptura, a "brecha escancarada", a ferida aberta sobre a pele. É através da brecha que se instaura a alteridade e o conseqüente desejo de uma experiência comum. Bataille confessa que não há sentido para o só: "Se eu quiser que minha vida tenha sentido para mim, é preciso que ela o tenha para outrem." ${ }^{270}$ No entanto, a aceitação de um outro tem duras conseqüências: o si perde, assim como toda sua segurança, o poder de ação sobre o mundo. Ora, comunicar torna-se então um ato sacrificial: eu me lanço, dou meu copo em sacrifício; como resposta, tenho a brecha para a descoberta do estranho. Tal concepção não se aproxima de maneira nenhuma dos pensamentos da comunicação como ação, troca, tampouco como facilitadora dos laços sociais ou instrumento civilizatório. Bataille aposta no caminho da angústia, caminho indeterminado, onde falta mesmo o chão. Somente ali a vida toma sentido verdadeiro: “A comunicação ainda é, como a angústia, viver e conhecer.",271 Mas isto não encerra a questão, pois é a partir daí que se instala na existência uma espécie de círculo paradoxal, no qual oscilam o saber e sua perda:

A angústia supõe o desejo de comunicar, isto é, de me perder, mas não a resolução inteira: a angústia é testemunha do meu medo de me comunicar, de me perder. A angústia é dada no tema do próprio saber: ipse, através do saber, eu queria ser tudo, logo comunicar, perder-me, entretanto permanecer ipse. Para a comunicação, antes que ela ocorra, colocam-se o sujeito (eu, ipse) e o objeto (em parte indefinido, até que seja inteiramente apreendido). O sujeito quer apoderar-se do objeto para possuí-lo /.../ mas ele só pode se perder. ${ }^{272}$

\footnotetext{
${ }^{269}$ Ibid., pág. 68.

270 Ibid., pág. 48.

${ }^{271}$ Ibid., pág. 45.

272 Ibid., pág. 59.
} 
Não há, no entanto, como fugir deste círculo vicioso e enlouquecedor, pois aquele que recusar seu destino comunicante, corre o risco de nele mesmo encontrar o declínio. Para Georges Bataille, a recusa de comunicar significa um meio de comunicação ainda mais hostil do que os outros e, por isso mesmo, o mais potente $^{273}$. Assim, vida e comunicação se confundem, formando o sentido próprio de uma existência que se opõe ao "projeto" e à dominação do sujeito sobre os objetos. Esse estatuto vital conferido à comunicação é apresentado e grifado pelo autor no seguinte fragmento:

Eu afirmava ao mesmo tempo: que a existência é comunicação - e que toda representação da vida, do ser e, geralmente de "qualquer coisa", deve ser revista a partir daí. ${ }^{274}$

E se a existência é comunicação, ela é múltipla e gera variações da experiência interior. Já vimos que o discurso deste filósofo tange o obscuro, mas ainda assim é dis-curso, no sentido grego de acordo com o lógos. O autor sabe que não tem outra escolha senão escrever e deixar pistas para os leitores que eventualmente venham a fazer parte de sua comunidade. Eis um ponto crucial de sua filosofia: a constituição de uma comunidade. Passo precioso para Bataille, pois a comunidade não é feita só de contemporâneos, mas de todos aqueles que, como ele, levam consigo a angústia do incomunicável, do inconfessável ou inadmissível (inavouable), enfim, da descontinuidade.

Assim, comunicar implica comunidade - e em suas várias manifestações. Há, certo, uma comunidade filosófica. Mas há, entre outras, a comunidade dos amantes. Não há como evocar esta questão sem considerar de perto a obra batailliana sobre o erotismo, que inclui, além do livro homônimo, anotações e ensaios publicados apenas postumamente. Para o filósofo, o erotismo tem como fundo a descontinuidade dos seres; e é este limite que faz do humano um incansável desejante de sua continuidade perdida. Tal abordagem toca aparentemente o vocabulário psicanalítico e lembra conceitos como as pulsões de vida e morte, desejo, narcisismo. Mas o próprio autor faz questão de sublinhar que seu trabalho sobre o erotismo, realizado durante décadas a fio, não tem nada a ver com a psicanálise: "Lamento, mas 
trata-se de abordagem filosófica", tal frase é dita tanto na introdução de $O$ erotismo quando em conferências realizadas na mesma época (1947) para platéias formadas pela intelectualidade francesa.

Partindo de visão incontornavelmente filosófica, Bataille apresenta o erotismo como uma forma muito especial de comunicação, pois confere a “aprovação da vida até mesmo na morte" ${ }^{275}$. Mais uma vez, não se trata de relação superficial ou derrisória, não se trata de comunicar a cidade ou os meios civilizatórios. A aprovação da vida até mesmo na morte envolve a entrega dos seres, um lançar-se no irreversível da experiência. E o irreversível leva sempre ao reino do tempo, melhor dizendo, da morte. O autor afirma que "somos seres descontínuos, indivíduos morrendo isoladamente numa aventura inteligível, mas que temos a nostalgia da continuidade perdida." ${ }^{276}$ Naturalmente, a busca de tal continuidade não é qualquer tarefa, já que exige a aposta no êxtase - do tudo perder e do perder-se sobretudo no êxtase erótico. Nenhuma garantia: a continuidade é instantânea, passageira, diz respeito à partilha do que no indivíduo é incomunicável e ao contrato da aventura travada somente entre pares, dá-se entre aqueles que se propõem, mesmo que brevemente, a viver o mesmo sentido.

Tal contrato do êxtase não deixa de ser, para o filósofo, uma grande promessa. Pode-se mesmo dizer que, neste ponto, seu pensamento toca a promessa metafísica, se bem que uma metafísica do instante. Tal promessa realiza-se na medida em que se torna possível a perda de si (sem haver nenhum si) na fronteira morteimortalidade e, sobretudo, no subseqüente retorno à temporalidade da consciência e da história. Daí ser o erotismo o limite da experiência interior, do proibido e de sua transgressão, cujos exemplos Bataille busca tanto nos personagens libertinos do Marquês de Sade quanto na devoção incondicional de uma Santa Tereza D'Ávila.

O erotismo, ao contrário das comunicações sociais, coloca o humano diante do descontínuo. As comunicações em sociedade operam inversamente ao erotismo, pois elas precisam da abertura à luz e do espaço público para, finalmente, funcionarem como tranqüilizantes. Elas apaziguam o terror da finitude e suas fantasmagorias; logo, comunicação como phármakon ou então como antídoto ao imperativo da entropia. Com o erotismo, ao contrário, o descontínuo se impõe como

275 BATAILLE, Georges. L'érotisme. In Oeuvres complètes, vol. X. Paris: Gallimard, 1990. Pág. 17.

276 Ibid., pág. 21. 
grande desterro. Não importa se erotismo dos corpos, dos corações ou do sagrado, o que se acede não tem nada a ver com o social, mas sim com a falta ilimitada, nostalgia da continuidade perdida: "A ação decisiva é o desnudamento. A nudez se opõe ao estado fechado, isto é, ao estado de existência descontínua. Trata-se de um estado de comunicação que revela a busca de uma continuidade possível do ser para além da dobra do si." 277

\section{8}

Há que se ter em conta as ressonâncias do desassossego batailliano na comunidade. Acéphale, ou acéfalo, foi um grupo fundado sobre o desejo de tornar comum a finitude, a ferida da existência, sua incomunicabilidade. Por isso, seus membros não hesitaram em colocar em marcha o sacrifício: deram suas cabeças em troca do êxtase e da experiência indizível. Maurice Blanchot confessa a distinção dessa comunidade inconfessável: "Acéphale permanece ligada a seu mistério; aqueles que participaram não estão tão certos de terem nela tomado parte." ${ }^{278}$ De fato, a comunidade se sabe finita, "pois tem em si o princípio da finitude dos seres que a compõem"279 - e estes seres não suportariam que fosse de outra forma. Com Georges Bataille, eles souberam levar a cabo sua incompletude: o humano vive dessa falta. A formação comunitária estaria, deste modo, baseada no que nela é incomum, incompleto, terminal. Como no erotismo, afirmação da vida até mesmo na morte. Em verdade, diz Blanchot, a comunidade só se forma e se revela pela morte. ${ }^{280}$

Mas de que morte este autor fala? Da única morte da qual podemos nos recordar, a do outro. É ela a finitude da qual sofremos e, para escondê-la de nossos olhos, inauguramos rituais, sociedades, culturas. A ela nos expomos, comunicamos: “Ora, a base da comunicação não é necessariamente a palavra, tampouco o silêncio, pois este é seu fundo e pontuação; é sim a exposição à morte, não mais de mim mesmo, mas do outro cuja presença viva e mais próxima já se mostra como a eterna e insuportável ausência." ${ }^{281}$ Diante dela, o desaparecimento sacrificial da própria

\footnotetext{
277 Ibid., pág. 23.

278 BLANCHOT, Maurice. La communanté inavonable. Paris: Minuit, 1983. Pág. 28.

279 Ibid., pág. 17.

${ }^{280}$ Idem.

${ }^{281}$ Ibid., pág. 46.
} 
cabeça é o que redime esse desaparecimento maior e inevitável do outro. Através do rito extático, o que se tem é a confirmação de um laço poderoso, laço de amizade. Com esta, descobrimos "desconhecido que somos nós mesmos e o encontro de nossa solidão, que apenas nós podemos experimentar." 282

Neste ponto já se percebe que a comunidade em questão não tem nada de mediano ou gregário. Seus membros se sabem sozinhos e mesmo duvidam de sua participação comunitária. Blanchot tenta, mais como advertência do que como definição, dar os traços dessa comunidade: “1) Ela não é uma forma restrita de sociedade, tampouco tende à fusão comunal. 2) Diferentemente de uma célula social, ela se proíbe de produzir e não tem como fim nenhum valor produtivo."283 Mas então para que ela serve? "Para nada, somente para estar presente com o outro até mesmo na morte, para que o outro não se perca solitariamente." 284 No entanto, se a comunidade não é o lugar de experiências medianas, também não é lugar de soberania: "Ela é aquilo que expõe enquanto se expõe. Inclui a exterioridade de ser que a exclui. Trata-se de uma exterioridade que o pensamento não controla, independente dos nomes que receba: morte, relação com o outro ou ainda palavra." 285 Por isso, não vence e não se sobrepõe a nada. Ela própria declina e se dobra à linguagem: "pressente-se que a comunidade, em sua própria derrota, está ligada em parte a um certo tipo de escritura." ${ }^{286}$ Isto é, mesmo sob o êxtase e suas conseqüência que tangem o indiferenciado, resta algo de conhecimento: experimentar o "fora de si (ou simplesmente o fora), que é abismo e êxtase, não deixa de ser uma relação singular." 287

Ao dialogar com Blanchot, o também acéfalo Jean-Luc Nancy desdobra a comunidade. Para ele, a essência mesma da comunidade é a finitude: "ela comparece, ou seja, é exposta." 288 Mas tal exposição só se dá graças à existência viva, ao que está lançado no mundo. O que se partilha, no limite, é o ser:

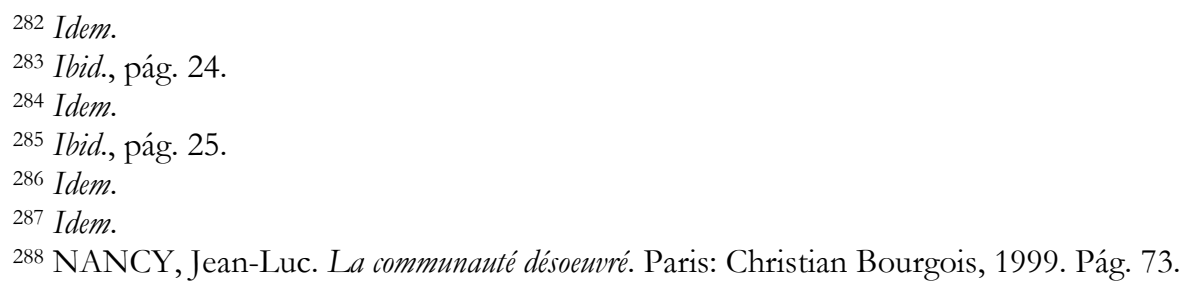


O que há de mais comum que ser, que o ser? Nós somos. O que partilhamos é o ser, a existência. Quanto à não-existência, não estamos lá para partilhá-la, ela não se dá à partilha. Mas o ser não é algo que possuiríamos em comum. $\mathrm{O}$ ser não é em nada diferente da existência, a cada vez singular. Diremos portanto que o ser não é comum no sentido de uma propriedade comum, mas que ele é em comum. Há algo mais simples do que isso a constatar? E no entanto haverá algo mais negligenciado do que isso, até aqui, pela ontologia? ? $^{289}$

Partilhar ou comunicar a condição inclui a aceitação de um ser em-comum. Não faz mais sentido trabalhar sobre conceitos ingênuos, diz Nancy, como isolamento separadamente de comunicação: ambos são uma única realidade. Este autor lembra que, para Bataille, não há seres completamente isolados, tampouco comunicação que seja independente de pontos de isolamento. Portanto, é preciso “tomar cuidado e rejeitar esses dois conceitos mal acabados, resíduos de crenças pueris. ${ }^{" 290}$ Mesmo a idéia de comunicação só deve ser aceita às custas de uma certa violência:

Eu emprego o termo "comunicação" tal como Bataille, ou seja, segundo o regime de uma violência permanente à significação da palavra, assim como naquilo que ela indica de subjetividade e intersubjetividade, no que esta palavra denota de transmissão de uma mensagem e de um sentido. No limite, este termo é insustentável. Eu o mantenho pois é algo que ressoa com "comunidade", mas sobreponho (o que é às vezes substituir) em seu lugar a palavra partilha. A violência que Bataille infligia ao conceito de "comunicação" era consciente de sua insuficiência. ${ }^{291}$

O cuidado vai ao ponto de evitar que a comunicação seja vinculada à idéia de ligação. "Ela não é uma 'ligação'; a metáfora da 'ligação social' se sobrepõe

\footnotetext{
289 Ibid., pág. 201.

290 Ibid., pág. 51.

${ }^{291}$ Idem.
} 
rudemente à de 'sujeitos' (ou seja, de objetos). ${ }^{292}$ Haveria uma ordem mais originária do que a da ligação: a do com-parecimento, agente de uma alteridade e de uma singularidade possíveis: "Esta ordem não se instaura, não se estabelece, tampouco emerge entre sujeitos (objetos) já dados. Consiste na aparição do outro como tal: você e eu (o entre nós), fórmula na qual o 'e' não tem valor de justaposição, mas de exposição." ${ }^{293}$ No com-parecimento, de acordo com Nancy, expõe-se o que é preciso saber ler segundo todas as combinações possíveis:

“- Toi (e(s)t) (tout autre que) moi [você é/e (tudo menos) eu]."

"Ou ainda, de modo mais simples: você me partilha."294

Essa partilha é o que garante a singularidade, embora titubeante, dos participantes do êxtase. Não há ligação nem comunhão, mas antes exposição. Assim, pode-se considerar a comunicação como "o fato constitutivo de uma exposição que define a singularidade." ${ }^{295} \mathrm{Em}$ seu horizonte, está a comunidade como aquilo que retira de cena todo resquício de individuação ontológica e se apresenta como finitude com-parecedora. O que não está isento de luto:

O que faz comunicar as singularidades não é exatamente aquilo que Bataille chamava de dilaceramento [déchirure]. O que é dilacerante, em verdade, é a apresentação da finitude na comunidade e pela comunidade - a apresentação do triplo luto que devo fazer: o da morte do outro, o de meu nascimento e o de minha morte. A comunidade é a conduta deste luto triplo (eu não diria que ela é o "trabalho" de tal luto, em todo caso, não somente: há na conduta do luto algo de mais simples e menos produtivo). Portanto, o que se encontra dilacerado não é o ser singular: ao contrário, este com-parece no dilaceramento. $^{296}$

\footnotetext{
292 Ibid., pág. 74.

${ }^{293}$ Idem.

${ }^{294}$ Idem.

${ }^{295}$ Idem.

296 Ibid., pág. 75.
} 


\section{9}

Não é mais questão de dar a cabeça em sacrifício. Há algum tempo já não há mais cabeça a sacrificar, tampouco pele ou corpo. O massacre está no ar. A vida sem pele manifesta-se não só no fantasmagórico das imagens mediáticas, mas também - e talvez principalmente - no monstruoso. Mas até que ponto isso tudo é apreensível? Como captar as reais estranhezas nascidas do imaginário, agora muito maiores do que nossa própria imaginação (como bem sinalizou Anders)? Este não é mais um caso para fronteiras ou superfícies. A monstruosidade vem do centro, como assevera Dietmar Kamper, do coração do homem. Este autor nos fala da aporia que é viver entre uma sociedade do sacrifício e uma outra, efetivamente monstruosa, a do massacre. A imagem difundida pelo humanismo de que o homem pode ser continuamente melhorado estaria, simultaneamente, ligada ao fato de ele também ser incorrigível. O que se chama "melhora" não responde com fidelidade aos apelos do progresso, das luzes. Assim, a civilização se vê impregnada de suas próprias contradições, do que sai ao seu controle, do que se civiliza em excesso. Kamper, assim como Bataille e Anders, também recorre à memória de seu século danificado:

As guerras e as aniquilações em massa do nosso século $[\mathrm{XX}]$ mostraram que nada têm a ver com o progresso geral no espírito da liberdade; que não há saída possível entre uma sociedade do sacrifício [Opfergesellschaft, que a si mesma devora, e uma sociedade do massacre [Massakergesellschaft], que vive às custas dos outros; que a antiqüíssima monstruosidade do ser humano apenas se disfarça, mas não pode ser abolida. Desde então, todo humano esclarecido sabe do que se trata quando se envergonha de integrar a espécie. ${ }^{297}$

A monstruosidade, portanto, faz-se perceptível não pela razão, mas sim pela imaginação: por imagens criadas ou recriadas endogenamente e, talvez por isso mesmo, assustadoras. Estão presentes desde sempre, sendo ao mesmo tempo familiares e estranhas, enfim unheimlich. Operam na oscilação entre o novo e o repetido, o aqui e o lá, o fora e o dentro. Kamper diz poeticamente que "monstros

297 KAMPER, Dietmar. Unmögliche Gegenwart: zur Theorie der Phantasie. München: Wilhelm Fink, 1995. Pág. 150. 
são máscaras do outro num mundo do mesmo." ${ }^{298}$ O problema maior é, quando pelos caminhos irreversíveis da técnica, a "monstruosidade entra explicitamente em jogo e não mais desaparece do plano das imagens [Bildfläche]. ${ }^{.299}$ Uma pequena chave para chegar a esse epicentro está no conceito de Unheimlich, o estranho-assustador, o terrífico próprio da condição humana que desde Sófocles dá pistas a pensamentos descentralizadores. Kamper faz menção ao Unheimlich, com foco especial sobre sua interioridade, seu caráter literalmente cordial. Além disso, a questão tange as vias tortuosas da dialética:

Com a interposição deste tema, há um outro lado da dialética usual a ser apontado. O Unheimlich não é dialetisável. É algo que irrompe do secreto, que arrebenta de dentro para fora como uma ferida supurada. É preciso fortalecer o receio de que a dialética do pátrio e do estrangeiro, bastante tematizada recentemente tanto como discussão quanto experiência, encobre ou substitui um problema muito pior, já que a partir dela nenhuma erva cresceu no jardim da razão. Contanto que o estranho mantenha-se possível como solo de ressonância para o próprio, como contra-imagem do si, como pólo que se coloque em uma silenciosa complementaridade, sobreviverá a base de tal debate que desde o Romantismo a Europa claramente acompanha e protege. O pior é que, sendo a homogeneidade do mundo a imanência sem alternativa de um princípio único, permite-se o auto-ocultamento das atuais discussões acerca do próprio, do estrangeiro, da propriedade cultural e da alienação política. Assim, o que acontece no interior do sistema torna-se explicitamente oculto através desta impermeabilização e encapsulamento. ${ }^{300}$

Impermeável o mundo, não sobram muitas alternativas para a percepção. $\mathrm{O}$ monstruoso é erroneamente tomado como algo vindo de fora, um alienígena, xenos na acepção mais própria do termo. Mas não é bem assim. A dialética do Unheimlich secreta lentamente o conteúdo de trocas perversas. Kamper explica: "O Unheimlich provém da troca entre o vivo e o morto, mais precisamente, do fracasso dessa troca.

\footnotetext{
298 Ibid., pág. 149.

${ }^{299}$ Ibid., pág. 150.

300 Ibid., pág. 178.
} 
O lugar de seu surgimento não é a margem, mas o centro; por assim dizer: o coração humano." 301 Isso iria contra uma mentalidade corrente, que defende que as vítimas da história empreendem uma marcha que sai da periferia rumo ao centro do poder. $\mathrm{O}$ que é no mínimo um equívoco de perspectiva, revelando um despreparo geral para o perigo. O que leva Kamper a afirmar: "Definitivamente, o perigo não vem de fora, mas sim aninhado no foco do si, no foco da humanidade do homem, no foco do humanismo europeu." 302

Torna-se cada vez mais difícil decodificar os acontecimentos. Os traços dialéticos presentes nas discussões sobre estrangeiridade, território, fronteiras terminam por abolir o outro. E não só: não havendo mais alteridade, toma lugar "uma apoteose do mesmo no espaço interno da mente, que não serve mais para a leitura do que acontece hoje." 303 Não há mais como tratar tais problemas, segundo Kamper, nos termos da propriedade e da alienação; e os homens não são mais capazes de compreender (ou nunca foram?) o que eles mesmos fizeram. Eles têm medo de habitar a própria imaginação, pois esta se tornou monstruosa. No entanto, aqueles que tiverem coragem, saberão que os "monstros são - e significam expoentes e sentinelas do imaginário. ${ }^{\text {304 }} \mathrm{E}$ a única forma de chegar ao seu fundo é recuperar os movimentos, dar nova vida ao corpo: "Quem ficar sentado, não pode constatar se, sobre a tela que dissimula o horizonte, são erigidas pontes que levem para o outro." 305

Trata-se de um caminho sem retorno. O homem, ao comer do fruto da árvore do conhecimento, abandonou definitivamente o paraíso. Não poderia ser diferente: "A partir daí, o paraíso se tornou um lugar pequeno demais para ele, entediante demais." ${ }^{\text {306 }}$ Mas tal abandono nos deixa a todos numa situação de permanente estranheza: sabemos que o paraíso não é mais o nosso lugar, mas guardamos dele a nostalgia. É por isso que, ainda hoje, há aqueles que se empenham inutilmente em recuperar o paraíso perdido. Mas tal procura, como bem define Kamper, "envenenou a história do mundo e espalhou infernos em todos os lugares

\footnotetext{
301 Ibid., pág. 179.

302 Idem.

${ }^{303}$ Idem.

${ }^{304}$ Ibid., pág. 185.

${ }^{305}$ Idem.

306 Idem.
} 
onde o antes havia paraíso." ${ }^{307}$ Descobrir esses segredos tão originários quanto o primeiro pecado exige o esforço de uma viagem: "O Unheimlich interior, desfiladeiro do coração, abre-se e dá o preço de seu segredo.”308

\subsection{0}

Com Sigmund Freud, o conceito de Unheimlich passa a fazer parte de uma via apreensível, instrumento de interpretação psicanalítica. O fato é que diferentes manifestações de Unheimlichkeit, de estranha-inquietude, levaram Freud a uma pesquisa cujos resultados não devem ser desperdiçados. Primeiramente, ele se preocupa em esclarecer o termo, que mesmo em alemão é pouco óbvio. É a própria indefinição da palavra Unheimlich que lhe chama a atenção, que solicita investigação. Assim, recorre aos dicionários disponíveis e a definições literárias, onde encontra definições diversas e às vezes opostas. Se não há para Unheimlich um senso comum, há pelo menos um uso comum: "ele surge, sem dúvida, do assustador, daquilo que suscita angústia e medo. E não é menos certo que esta palavra tenha sido sempre usada de modo que não se pode dá-la uma definição precisa. Assim, na maior parte do tempo, ela evoca o medo em geral." ${ }^{309}$

O importante aqui é salientar que o Unheimlich pertence ao domínio da estética. Seu mistério está no processo de apreensão que o envolve. Nesta direção, Freud tentará mostrar como é possível o familiar converter-se em estranho e assustador. "O que nos parece mais interessante é que entre as múltiplas nuances de significação, a pequena palavra Heimlich (oculto e familiar) se apresenta em concordância ou mesmo coincide com seu antônimo Unheimlich." ${ }^{310}$ Chamou-lhe a atenção uma nota de Schelling, que enuncia o conceito de Unheimlich como algo para o qual nossa expectativa não está preparada. Para Schelling, é unheimlich tudo o que deveria permanecer secreto, na sombra, mas aparece. Tal definição guiará não somente Freud, mas outros autores posteriores do século XX.

\footnotetext{
307 Idem.

308 Idem.

309 FREUD, Sigmund. Das Unheimliche (1919h). In: Studienausgabe, vol. 4. Frankfurt: Fischer, 1970. Cotejada com a tradução francesa de Bernand Féron: L’inquiétante étrangeté. Paris: Gallimard, 1972. Pág. 229 do original.

310 Ibid., pág. 236.
} 
No contexto psicanalítico, é a ambivalência entre consciente e inconsciente que deve ser considerada com mais cuidado: "Heimlich (oculto-familiar) é, pois, uma palavra cujo significado evolui na direção de uma ambivalência, até que acabe por coincidir com seu contrário, o Unheimlich. Unheimlich é de certa forma uma espécie de Heimlich. ${ }^{311}$

O principal exemplo tomado para seu texto não vem da casuística de pacientes, mas da literatura. Um conto de Ernst Theodor A. Hoffman, chamado "O homem da areia", dá os subsídios para a confirmação de suas teses, que culminam no medo edípico da castração. Mas, se por um lado a resposta psicanalítica já está dada, o caminho até ela não precisa ser necessariamente desconsiderado. Com a interpretação do conto, vê-se que o Unheimlich se manifesta por vezes através do medo de perder os olhos, o que em alemão se diz Augenangst. Assim sintetiza Freud o enredo da estória cruelmente dirigida às crianças:

O homem da areia é um malvado personagem que vai até as crianças que não querem dormir. Ele joga areia em seus olhos até que comecem a sangrar. Então, coloca as crianças num saco e as leva, sob a luz da meia lua, para que sirvam de alimento a seus próprios filhos. Os filhos do homem da areia ficam dentro de uma espécie de ninho, têm bicos pontudos como corujas, e começam a bicar os olhos das crianças humanas que não são boazinhas. ${ }^{312}$

A leitura psicanalítica nos traz à memória que o medo de perder os olhos é uma aflição infantil. Muitos adultos continuam sujeitos a tal angústia e não temem nenhum outro mal que não seja ligado a lesões no olho, desenvolvendo a partir disso traços efetivamente fóbicos ${ }^{313}$. Freud, baseado no estudo dos sonhos e também dos mitos, concluiu que o medo de perder os olhos, o medo da cegueira, é costumeiramente um substituto ao medo de castração: "mesmo o auto-cegamento do Édipo mítico seria uma atenuação da pena de castração, única pena adequada para seu caso. ${ }^{\text {314 }}$ Ele cita, além do repertório literário, outros exemplos retirados de

\footnotetext{
311 Ibid., pág. 237.

312 Ibid., pág. 239.

313 Ibid., pág. 243.

314 Idem.
} 
relatos de pacientes. Um deles, que também relaciona uma situação unheimlich ao olho, é o mau-olhado [der böse Blick], considerado por Freud como uma das formas de superstição mais inquietantes [unheimlich] e difundidas: "Alguém que possua alguma coisa que seja ao mesmo tempo preciosa e frágil, percebe a inveja dos outros e projeta sobre eles a mesma inveja. Tais situações se traem pelo olhar, mesmo quando se recusa a expressão verbal." ${ }^{\text {315 }}$ Para além do medo de castração, Freud traz à tona todos os medos, estranhamente condensados - posto que surgidos no familiar. Eles diz que o Unheimlich não é em realidade nada de novo ou estranho, mas qualquer coisa que para a vida psíquica é sempre familiar e que, por um processo de recalque, se tornou estrangeiro. A relação com o recalque esclarece, portanto, a definição de Schelling, segundo a qual o Unheimlich é algo que deveria permanecer sob a sombra mas que saiu para a luz. ${ }^{316}$

\subsection{1}

Sarah Kofman vê na mulher - e não no medo de castração - fonte de Unheimlichkeit, de terror. Recuperemos inicialmente este trecho do texto de Freud:

É freqüente homens neuróticos declararem que, para eles, o órgão sexual feminino é algo unheimlich. Mas acontece que esta Unheimlichkeité, em verdade, a entrada para antiga terra natal [Heimat] do pequeno garoto, entrada para o lugar no qual todos estiveram um dia. "O amor é saudade" [Heimweb] diz um ditado, e quando alguém em seu sonho pensa num lugar ou paisagem: "Isto é para mim conhecido, eu já estive aqui uma vez”, a interpretação nos autoriza a substituir este lugar pelo sexo ou corpo da mãe. O Unheimlich é, portanto, neste caso a antiga familiaridade [das Heimische], o íntimo. O prefixo un na palavra das Un-beimliche é a marca do recalcado. ${ }^{317}$

\footnotetext{
315 Ibid., pág. 253.

316 Ibid., pág. 254.

317 Ibid., pág. 259.
} 
Devido a essa relação com o lugar de origem, verdadeira terra natal, a mulher seria uma espécie de câmara obscura da cultura. Seu destino é maquiar, esconder, mascarar o terror de suas entranhas. Bela por fora, terrível por dentro. O investimento na beleza e nas formas harmoniosas pode ser, assim, uma maneira de encobrir o terror causado pelo feminino. E todo terror geralmente é combatido ou pelo belo ou pelo cômico. Para tratar dessa relação tragi-cômica, Sarah Kofman, num texto sobre Nietzsche, retoma o mito grego de Baubô ${ }^{318}$, personagem que, ao levantar a saia, faz rir Deméter, deusa então enlutada por causa da partida de sua filha Perséfone ao Hades. Baubô é uma velha mulher, já estéril, que ao mostrar a nudez de seu ventre gera um efeito paralisante: "Quando uma mulher levanta suas saias, provoca ou o riso ou a fuga, de tal maneira que este gesto possa ser utilizado como meio apotropaico: o ventre feminino faz o papel de uma cabeça de medusa." 319

Mas Baubô também recebe outras personificações ou simbolizações. Ela pode significar, no limite, a própria vida:

A figura de Baubô nos vem dizer que uma lógica simples é incapaz de compreender a vida, que esta não é nem profundidade nem superfície, pois atrás do véu sempre há um outro véu, atrás de uma camada de pintura há sempre uma outra camada; ela significa também que a aparência não deve despertar nem o ceticismo nem o pessimismo, mas o riso afirmativo de um vivente que, apesar da morte, sente que a vida pode retornar infinitamente. ${ }^{320}$

Esta personagem nos encaminha para o entendimento de que a absoluta nudez feminina não existe. Há sempre algo para encobri-la, um véu ou uma imagem. É assim que a imagem do nu esconde o próprio nu. Esconde porque ninguém consegue contemplá-lo sem recorrer ou ao riso ou à fuga; não há quem consiga deter-se na nudez. É preciso "sair" dela. Mas há vários tipos de saída, sendo alguns perversos. Um exemplo é o fetiche, que constitui-se numa recusa em ver e, mais grave ainda, na recusa em ver sua própria causa, sua origem, seu lugar de nascença.

318 KOFMAN, Sarah. "Baubô: pervertion théologique et fétichisme”. In: Nietzsche et la scène philosophique. Paris: UGE, 1979. Pág. 294.

${ }^{319}$ Idem.

320 Ibid., pág. 295. 
Sarah Kofman sugere que "perverso é aquele que quer a morte ou, pior, que não pode querer outra coisa senão a morte, já que ele próprio está morto.”321

Isso nos reenvia à questão freudiana das pulsões de vida e de morte e, sobretudo, de seus vínculos com a sexualidade. Perverso é aquele que, através do fetiche, manifesta um desequilíbrio entre as duas pulsões e que começa a relacionarse com o desvio, com a saída, e não mais com o objeto. Por isso são tão importantes detalhes, tecidos, roupas e imagens. O perverso/fetichista fixa seu desejo no tempo e no espaço. É incapaz de realizar-se no movimento vivo e no calor dos corpos. Seu vínculo é com o que está morto, fixo.

A nudez da mulher seria, assim, um tipo de Unheimlich, de "estranheza inquietante", uma mistura de terrífico e maravilhoso. Essa palavra alemã, que Freud trata no texto de 1919, significa inicialmente o extra-ordinário, o que sai do comum. No limite, ela designa o assombro, o que vem à noite para atormentar o sono não só das crianças, mas também dos homens adultos. Pesadelo, espécie de não-familiar, mas que se manifesta dentro do familiar. Sarah Kofman relaciona o termo Heim (lar) com o advérbio medieval de origem indo-européia mar. Este mar significa igualmente assombro e está presente em palavras modernas como cauchemar, nightmare (pesadelo), mer (mar) e mère (mãe).

Proliferação medieval da infelicidade [malheur], elemento familiar da língua literária da Idade Média, mar evoca a 'infelicidade de um destino essencialmente dramático, é palavra de ódio ou angústia que se pronuncia quase ritualmente em certos textos medievais'. /... $\mathrm{Na}$ poesia lírica nãocortesã, mar é signo da angústia e da fraqueza, do amor impossível ou não partilhado. Fórmula masculina do amor não correspondido, é sobretudo a figura maior da deploração feminina. ${ }^{322}$

Tal mar, que nos põe numa terrível marginalidade, também está presente na câmara. Ou pior: dela advém, é gerado em seu interior. Habita simultaneamente o estranho e o familiar, o maravilhoso e o terrível, o lúcido e o incompreensível. No entanto, esta mesma câmara não pode, jamais, constituir-se em morada (Heim). Ela é

\footnotetext{
321 Ibid., pág. 266.

322 KOFMAN, Sarah. Comment s'en sortir. Paris: Galilée, 1983. Pág. 107.
} 
apenas lugar de passagem (de parto?), onde nem o homem nem as imagens podem de-morar. É desterritorializante, extra-ordinária e por isso assustadora (Unheimlich). Ou então, para nos confundir um pouco mais, talvez seja seu próprio contrário: a câmara é a única morada possível, mas que se abre por um lampejo, breve e marcado no tempo. E essa abertura se chama a própria vida.

\subsection{2}

Da passagem, uma nota.

"Estou só de passagem”, “citou isso de passagem”, “já passou”. O que dizem efetivamente estas frases: algo não parou, não se deteu, não explorou sequer a superficialidade. Só passou. Terá deixado rastro? Ou somos nós que recusamos a aceitar permanência desse rastro? Quando, com a pretendida finura francesa, pronunciamos a expressão "en passant", o que há de fato é um descompromisso; nós nos des-com-prometemos com o que passa. E forjamos a idéia de que aquilo nada significa para nós - quando na verdade dele já nos apropriamos, trancamos na caixa de guardados. Violência contra o objeto. Ou hábito civilizatório da coleção. 


\section{II - Danificações}




\section{Ao Deus Kom UniK Assão}

Carlos Drummond de Andrade 323

Eis-me prostrado a vossos peses

que sendo tantos todo plural é pouco.

Deglutindo gratamente vossas fezes

vai-se tornando são quem era louco.

Nem precisa cabeça pois a boca

nasce diretamente do pescoço

e em vosso esplendor de auriquilate

faz sol o que era osso.

Genuncircunflexado vos adouro

vos amouro, a vós sonouro

deus da buzina $\&$ da morfina

que me esvazias enchendo-me de flato

e flauta e fanopéia e fone e feno.

Vossa pá lavra o chão de minha carne

e planta beterrabos balouçantes

de intenso carneiral belibalentes

em que disperso espremo e desexprimo

o que em mim aspirava a ser eumano.

Salve, deus compato

cinturão da Terra

calça circular

unisex, rex

do lugarfalar

comum.

Salve, meio-fim

de firinfinfim

plurimelodia

distribuída no planeta.

323 In: As impurezas do branco, 1973. 
Nossa goela sempre sempre sempre escãocarada engole elefantes

engole catástrofes

tão naturalmente como se.

E PEDE MAIS.

A carne pisoteada de cavalos reclama

pisaduras mais.

A vontade sem vontade encrespa-se exige

contravontades mais.

E se consome no consumo.

Senhor dos lares

e lupanares

Senhor dos projetos

e do pré-alfabeto

Senhor do ópio

e do cor-no-copo

Senhor! Senhor!

De nosso poema fazei uma dor

que nos irmane, Manaus e Birmânia

pavão e Pavone

pavio e povo

pangaré e Pan

o Ré Dó Mi Fá Sol-

apante salmoura

n’alma, cação podrido.

Tão naturalmente como se

como ni

ou niente.

Se estou doente, devo estar doentes.

Se estou sozinho devo estar desertos.

Se estou alegra, devo estar ruidosos.

Se estou morrendo, devo estar morrendos? 


\author{
Cumpro. Sou \\ geral. \\ E pouco? \\ Multi \\ versal. \\ É nada? \\ Sou \\ al.
}

Dorme a tumba a cultura oral.

Era uma vez a cultura visual.

Quando que vem a cultura anal

na recomposta aldeia tribal?

O meio é a mensagem

O meio é a mensagem

O meio é a mixagem

O meio é a micagem

A mensagem é o meio

de chegar ao Meio.

O meio é o ser

em lugar dos seres,

isento de lugar,

dispensado meios

de fluorescer.

Salve, Meio. Salve, Melo.

A massa vos saúda

em forma de passa.

Não quero calar junto do amigo.

Não quero dormir abraçado

ao velho amor.

Não quero ler ao seu lado.

Não quero falar

a minha palavra

a nossa palavra. 
Não quero assoviar

a canção parceria

de passarinho/aragem.

Quero komunikar

em código

descodificar

recodificar

eletronicamente.

Se komuniko

que amorico

me centomultiplico

scotch no bico

pararico

rio rico

salpico

de prazer meu penico

em vosso honor, ó Deus komuniko.

Farto de komunikar

na pequena taba

subo ao céu em foguete

até a prima solidão

levando o som

a cor, o pavilhão

da komunikânsia

interplanetária interpatetal.

Convoco os astros

para o coquetel

os mundos esparsos

para a convenção

a inocência das galáxias para a notícia

a nivola

o show de bala

o sexpudim

o blablabum. 


\author{
E quando não restar \\ o mínimo ponto \\ a ser declarado \\ a ser invadido \\ a ser consumido \\ e todos os seres \\ se atomizarem na supermensagem \\ do supervácuo \\ e todas as coisas \\ se apagarem no circuito global \\ e o Meio \\ deixar de ser Fim e chegar ao Fim, \\ Senhor! Senhor! \\ quem nos salvará \\ de vossa própria, de vossa terríbil \\ estremendona \\ inkomunikhassão?
}




\section{À GUISA DE CONCLUSÃo}

Por vezes os textos teóricos imitam a música: pede-se, mais por elegância do que por estilo, que tenham uma última nota, um ponto final. E esta última nota devo a Adorno, mais exatamente ao subtítulo de seu livro Minima moralia, que em português traduziu-se como "reflexões da vida danificada" (Reflexionen aus dem Beschädigten Leben). Encontrei na danificação um certo método de trabalho guardadas todas as sutilezas armazenadas durante os últimos séculos no que diz respeito às palavras "método" e "trabalho". A tarefa não consiste em danificar, mas em perlaborar a partir do que já está em cacos, dilacerado. De todo modo é uma filosofia corporal, na direção de uma terapia contra o dilaceramento da carne e de sua perda de campo frente ao espírito. A carne precisa de casa e cuidado, de terra onde possa vaguear, flanar, sujar os pés. O espírito, este, não precisa de nenhuma terra ou lar (Heim), pois ele próprio é o desterro (Unheimlich).

Resultado da danificação, a única escrita que me permito neste momento é a de uma carta. Essa imagem tão movente - e ao mesmo tempo tão enraizada na cultura - me permite dizer o que resultou de uma pesquisa de cinco anos e cumprir a tarefa desconfortável de deixar algo escrito. É claro que essa decisão, ou permissão, vem acompanhada de uma imensa melancolia epistemológica, de um cansaço que pode ser não o de uma estudante, mas de uma civilização que parece ter esgotado suas energias, que parece sucumbir a cada dia em seu próprio excesso, em sua desmesura científica, seu tudo dizer e tudo comunicar. Não que tudo já esteja dito ou pensado, mesmo por que ainda não inventaram régua para isso. É um outro excesso que está em questão, um acúmulo que em vez de acrescentar desnorteia, que faz casa no despaisamento. Faço parte desta civilização, deste Ocidente que é terra do crepúsculo e que não pode ter outro destino se não escurecer; sou resultado inevitável de diferentes perspectivas em chiaroscuro que circulam nos ambientes universitários; e sou meu próprio instrumento de trabalho para investigar a comunicação entre os humanos. Por estas razões, a única escrita que me aparece como possível, neste momento, é a de uma carta. Sei que muitos colegas não pensam como eu. Estão em outras trilhas e seguem suas pesquisas segundo perspectivas que se 
multiplicam e se recombinam em cada um. Não posso em momento algum desprezar esses que ainda têm o vigor para escrever efetivas teses, tratados, comentários, antologias. Essa gente ainda existe, mas luta sem trégua e está infelizmente dispersa em meio ao excesso. Eles são os que tomam parte na guerra, que conhecem o sentido do chão, da terra-aí; lutam por algo que se mantenha pátrio, familiar, lutam pelo direito de se sentirem em casa. A eles remeto esta carta.

Carta pressupõe distância, talvez um certo mal-estar, saudade. É preciso estar longe de casa, do lugar que parece o mais próprio e comum. É preciso sentir falta: um amigo que partiu, um desejo de notícias. De todo modo, aquele que escreve uma carta o faz pelo menos por dois motivos: ou partiu ou foi partido. Tem sempre a sensação de que há algo deslocado, longe do lugar-comum “cada coisa em seu lugar". No mais, há um desejo de correspondência, de troca viva, de alteridade, uma mistura de nostalgia da proximidade com elogio da distância. É com esta intenção que escrevi este trabalho: corresponder. E também de arriscar no jogo de vários outros conceitos-chave relacionados: carta como letra, mensagem, relato, missiva, epístola, troca, mapa, plano, envelope, peça de baralho.

Se bem que neste jogo uma carta faltou. E faltou necessariamente: a narrativa. Corresponder não é narrar, ainda não. É relato precoce de viagem que não terminou. É contar o que se vive enquanto se vive, impressões, algo mais próximo do diário de viajante ou da reportagem. Uma carta não pode ser narrativa, simplesmente porque esta última pressupõe - além da imprescindível vivência - maturação, tempo. E não há mais tempo para amadurecer. Não há mais tempo para nada, inclusive nos ambientes universitários que, pela própria natureza de sua atividade, deveriam se manter como reduto de resistência. Se o tempo é o que nos confere condição humana, finita, temos tanto direito a ele quanto à nossa própria mortalidade.

Por isso aqui escrever uma carta - e não narrativa, tampouco tese nos moldes canônicos universitários. Desde Walter Benjamin, sabemos que o que se conta nos livros e jornais é tudo menos narrativa. Não há mais a possibilidade de comunicar o vivido pela voz. Depois de uma guerra, os homens voltam calados, "não mais ricos -

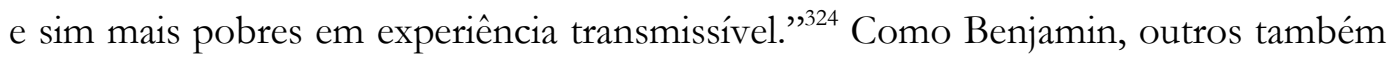
preferiram fazer tabu da palavra narrativa: Maurice Blanchot excluiu o termo de

\footnotetext{
324 BENJAMIN, Walter. "Der Erzähler: Betrachtungen zum Werk Nikolai Lesskows" (1936). In:
} Medienästhetische Schriften. Frankfurt: Suhrkamp, 2002. 
todos os seus textos publicados, alegando que depois de Auschwitz não é mais possível narrar. Georges Bataille e Sarah Kofman participaram do mesmo acordo tácito. Quanto às teses universitárias (e à formação acadêmica dos jovens), a impressão é de que algo semelhante se passa. A obrigação de produzir em curto prazo e acumular pontos segue caminho contrário à reflexão. Não que isso se deva a algum fenômeno parecido com Auschwitz; os estudantes de minha geração não viram homens sendo transformados em cinzas nos campos de concentração. Muitos sequer sabem o que lá aconteceu. Outro tipo de silêncio nos atinge, um silêncio que na verdade é barulho, voz perdida entre tantas outras. Mesmo nossas leituras são feitas de maneira funcional, rapidamente, visando produtividade. E de uma coisa sabemos bem: quem não tem tempo para ler, sofre de má digestão. Falta-nos aquilo que prescreveu Friedrich Nietzsche a todos os dispépticos do espírito, a nós homens modernos: o ruminar ${ }^{325}$.

Tal cenário é certamente bastante conhecido de meus destinatários. As redações universitárias, fundadas primeiramente na tradição hermética medieval e mais tarde no contexto humanista das luzes, refletem os processos de produção e conhecimento de suas épocas. Mas não se limitam a isso, já que têm por vocação um questionamento endógeno, de crítica e muitas vezes de resistência. De Nietzsche também ouvimos que o filósofo tem como alta tarefa ser a "má consciência de seu tempo" 326 ; a afirmação é válida não apenas para filósofos, mas para todo intelectual que tiver bons ouvidos e um pouco de coragem.

Assim entendido, um texto de doutorado é sempre mais que uma tese - e principalmente menos, se considerarmos as barreiras que se impõem, os impedimentos de ordem metodológica, social ou política. Se há quarenta anos no Brasil tinha-se dificuldade para dizer o essencial, por falta de liberdade, hoje a dificuldade está em localizar este mesmo essencial; ou em outras palavras, em localizar os campos de força, os temas e problemas que se perdem no interminável lixo de dados, data trash, como bem descreveu nos anos 90 o autor Arthur Kroker.

A questão é mais aguda nas ciências humanas. Por mais que se proponham métodos ou estratégias de ação comum, os caminhos de cada pesquisa tendem a se particularizar ao extremo. Não cabe recorrer a manuais metodológicos e sim

\footnotetext{
325 Genealogia da Moral. Prólogo, \ 8.

326 Além de bem e mal, $\$ 212$.
} 
desenvolvermos nosso próprio procedimento, calcado como um rastro de autenticidade, assinatura possível da época para si mesma. Assinatura de carta, confissão da má consciência necessária ao conhecimento: se houvesse escolha, textos vigorosos se imporiam e mostrariam seus objetos com clareza. Mas dele, do objeto, se existe é malin como diz Baudrillard, malicioso, adora esconderijos e caminhos sinuosos. Cabe ser investigado em sua trilha originária, o humanismo, como ponto de sujeição (subjectum) do homem, de sua auto-domesticação. Somente certas cartas (ou as cartas certas?) dariam conta de tais objetos fugidios. No entanto, ainda com Nietzsche, poderia-se arriscar: se cartas não são exatamente fruto de uma escrita vigorosa, são pelo menos sinal de convalescença ${ }^{327}$. Peter Sloterdijk, lembrando o escritor do romantismo Jean-Paul, diz: "Livros são cartas dirigidas aos amigos, apenas mais longas." 328

Vem portanto da philia a autorização para corresponder(me). Amizade - e não domesticação - é o que efetivamente cria os vínculos do saber. Nestes termos pode-se eventualmente constituir uma comunidade, como a que Georges Bataille travou não só com seus contemporâneos da revista Acéphalle, mas igualmente com Nietzsche e Sade. Conseqüentemente, desaparece qualquer resíduo da dita neutralidade científica. Para além do método, o que alguns chamam de referencial bibliográfico é na verdade uma comunidade de correspondentes, com alguma sintonia, mas também aberta aos conflitos e sem nenhuma aspiração ao consenso. Rege-se pelo princípio das afinidades eletivas. Para corresponder, também são importantes os pontos de resistência, pois asseguram uma certa regulação dos vínculos. Resistência a discursos, estilos, tempos e textos, sempre colocados lado a lado, lidos e analisados. Enquanto escrevo esta carta, tal como quem recorre a pressupostos metodológicos, atento a resistências de meu próprio texto, a momentos de hesitação, ao que foi silenciado. Resistir não está na disposição da contingência - e sim da necessidade de se tomar corpo e pele na direção contrária às filosofias da

\footnotetext{
327 Cauteloso com relação a esse gênero, em fragmento da primavera de 1978 (IV-28[56]), deixa o jovem Nietzsche: "Contra escrever cartas entre amigos. Tão logo se começa a escrevê-las, começa-se a errar." Por outro lado, o hábito da correspondência pode ser alívio para uma vida cercada de tudo o que é mediano; em Humano demasiado bumano, seção 319, está: "Quem não escreve livros, pensa muito e vive em companhia inadequada, será normalmente um bom escritor de cartas".

328 SLOTERDIJK, Peter. Regeln für den Menschenpark. Frankfurt am Main: Suhrkamp, 1999. Pág. 7.
} 
representação e da exclusão. Por este motivo cada trabalho universitário, sob o nome de tese ou não, não deve mascarar seu processo de construção, suas condições e fronteiras. Aqui, bem entendido, não falo de condições pessoais, mas de um contexto disseminado, dependente de políticas educacionais, financiamentos, avaliações, ritmos impostos, lógicas de mercado. Os trabalhos universitários devem antes de tudo, corresponder, comunicar algo.

Meu objeto de estudo é a comunicação. Durante os últimos cinco anos meditei (e continuo meditando) sobre pequenos-fundamentais problemas que a envolvem. Um deles é a resistência, que na pesquisa apareceu sob diversas formas: fronteira, passagem, terror, mesmo amizade ou philia. Comunicar é resistir ao indiferenciado, ao caos, mas sempre os absorvendo e novamente transpirando; é trazer na pele os traços da finitude. Apesar do "seqüestro do comum", como vimos no segundo capítulo, ou quem sabe graças a ele, em vez de método o que se constituiu aqui foi uma comunidade - de falas, encontros, mestres e alunos, livros e leitores, contemporâneos e extemporâneos. Não é preciso aqui anunciar quem são os membros: vários deles já foram apresentados no texto da tese; alguns participaram com intervenções, indicações de leituras, aulas, conversas nos corredores universitários, saguões de aeroportos, mesmo na solução de entraves burocráticos; outros permanecerão anônimos, como preferem e merecem. O que importa é que, ao fim da escrita, reconheçamos uns com os outros que o processo intelectual, apesar de muitas vezes solitário, não é de modo algum isolado.

Depois disso, sobre o que se entende por método hoje, o que dizer? Que contemporâneos (em alemão, Zeitgenossen, os companheiros da época) recolheram de Nietzsche a genealogia, de Foucault a arqueologia, de Derrida e Kamper a rastreologia. ${ }^{329}$ Em homenagem a esta comunidade formada em torno de um objeto comum, a comunicação, gostaria de expor a seguir os traços de minha própria colheita, uma porologia:

\footnotetext{
${ }^{329}$ O subsídio para esta colheita veio principalmente dos encontros nos dois grupos de pesquisa que freqüentei em São Paulo: FILOCOM, Núcleo de Estudos Filosóficos da Comunicação, localizado na ECA, coordenado por Ciro Marcondes Filho; ali, desde 2000, estudou-se sistematicamente a obra de tais autores; CISC: Centro Interdisciplinar de Semiótica da Cultura e da Mídia, cujo coordenador é Norval Baitello Júnior, da PUC, com membros de desta e de outras instituições tanto brasileiras e como do exterior. A eles expresso aqui gratidão e respeito.
} 
- De vital importância foi o desenvolvimento da pesquisa junto a um projeto coletivo, o FILOCOM. Dali vieram o subsídio e o apoio para trabalhar a comunicação sob um prisma que foge aos discursos dominantes, às pesquisas concentradas unicamente nos meios de massa e em suas conseqüências no âmbito da dominação social ou política. Por isso aqui, gostaria de citar um trecho dessa pesquisa maior, coordenada pelo orientador desta tese. Apesar de longa a citação, interessa segui-la na íntegra:

\section{O conceito de comunicação aqui utilizado:}

A comunicação não é ontológica, no sentido de não ser algo estável, fixo, consistente; nela nada se transfere, ela não é uma "coisa", menos ainda uma coisa única que como vai, assim é recebida. Por isso, "não sendo nada", ela não pode encerrar nenhuma verdade, não pode ser "traduzida", não há uma chave que nos diga o que a coisa significa, quer dizer, representa.

Comunicação é antes um processo, um acontecimento, um encontro feliz, o momento mágico entre duas intencionalidades, que se produz no "atrito dos corpos" (se tomarmos palavras, músicas, idéias, também como corpos); ela vem da criação de um ambiente comum em que os dois lados participam e extraem de sua participação algo novo, inesperado, que não estava em nenhum deles, e que altera o estatuto anterior de ambos, apesar de as diferenças individuais se manterem. Ela não funde duas pessoas numa só, pois é impossível que o outro me veja a partir do meu interior, mas é o fato de ambos participarem de um mesmo e único mundo no qual entram e que neles também entra.

A comunicação não está na difusão em massa dos jornais, rádios, televisões, revistas, publicidades de rua e semelhantes; aí ela é apenas difusão, eu emito sinais e formas livremente e alguém os capta, mas, rigorosamente, não se trata de comunicação, pois não há ação recíproca, a troca, o aprendizado instantâneo e num mesmo ambiente contextual de um com o outro. Quer dizer, a comunicação não se realiza no expresso, no intencional, na maquiagem que pretendemos de nós, de nossas coisas, de nossos produtos, de nossas ações; tudo isso fornece sinais de nós, que são decodificados livre e aleatoriamente pelos que são por eles sensibilizados. No não-intencional, na 
imagem que transmitimos incontroladamente de nosso corpo, de nossa postura, de nossa expressão, deixamos entrever o que há de sincero em nós. São da mesma forma sinais, só que, desta vez, não intencionais. Nenhum dos dois é rigorosamente comunicação.

Comunicação tampouco é instrumento, mas, acima de tudo, uma relação entre mim e o outro ou os demais. Por isso, ela não se reduz à linguagem, menos ainda à linguagem estruturada e codificada numa língua. Ela ultrapassa e é mais eficiente que esse formato, realizando-se no silêncio, no contato dos corpos, nos olhares, nos ambientes. ${ }^{330}$

- Quanto ao poro como passagem para a comunicação, foi considerado como ponto simultâneo de fluidez e resistência, pois só se passa quando há atrito, condição imprescindível para o rastro;

- Em seguida, com relação à con-vocação da comunidade bibliográfica, forma-se uma rede de ambivalências, chegando-se ao ponto em que ela mesma se convoca: de Nietzsche chega-se a Bataille, Blanchot e destes a Sarah Kofman, que por sua vez resiste a Heidegger, que se oferece em diálogos tensos com Derrida. Não há membros centrais ou centralizadores neste caso, já que um leva ao outro. Poderíamos começar por exemplo com Dietmar Kamper e sua chegada a Bataille, e assim por diante. O privilégio ou hierarquização de tal ou tal pensamento não se dá no interior da rede, bem entendido, mas mais tarde no processo de redação do trabalho ou tese, quando as perspectivas tendem inevitavelmente a uma ordenação por prioridades ou campos de força temáticos.

- Um terceiro momento da coleta porológica toca em referências extrateóricas. Noutras palavras, na formação de um entorno (Umwelt), mundo paralelo à tese universitária, organizado por outros discursos, porém tão condensados e intensos que deles se extrai o fundamental. Falo de uma relação endodérmica do texto principal com a poesia: lição de medida e de ritmo, de resistência ao dizer excessivo, de respeito à respiração tanto de quem escreve como de quem lê. O ponto de partida é Carlos Drummond de Andrade, por soprar os espíritos de seu tempo assim como fizeram Paul Éluard ou Paul Celan, porém dando aos meus ouvidos a

330 MARCONDES Filho, Ciro. Até que ponto, de fato, nos comunicamos. São Paulo: Paulus, 2004. Pág. 15. 
familiaridade da língua portuguesa. (Principalmente durante o período de pesquisa na Alemanha, Drummond foi para mim um cantor de exílios, de Heimweh e Unheimlichkeit, e foi antes de tudo o cantor da porosidade. Com ele aprendi: "em mim o que resiste são teus poros", que "Fulana diz mistérios, diz marxismo, rimmel, gás. Fulana me bombardeia, no entanto sequer me vê. / E sequer nos compreendemos." ${ }^{331} \mathrm{Ou}$ ainda o lembrete de que a razão abre aporias que nem ela resolve: "Outros dias virão / E novas coxas e ventres te comunicarão o calor da vida. /.../ O recurso de se embriagar. O recurso da dança e do grito, o recurso da bola colorida, o recurso de Kant e da poesia, todos eles... e nenhum resolve." ${ }^{\text {332 }}$ Simplesmente porque a "a vida é gorda, oleosa, mortal, sub-reptícia." ${ }^{333}$ Em noite de inverno o poeta mineiro consola o refugiado Celan: "Confissões difíceis pedem folha branca. Não grite, não suspires, não te mates: escreve.” E Celan responde brilhantemente: "Agora juntas ao teu peso tudo o que é leve, agora desmascaras o sempre nomeado mas sem nome, agora manda os martelos-mecânicos, os furasílabas, para debaixo do esporão daquele que te leva a saltar para o outro lado da ardilosa madeira da sebe, agora escreves." 334 )

- A viagem: com uma bolsa de estudos na Alemanha de Nietzsche, Heidegger, Kamper, também de outros pensamentos menos centrais mas imprescindíveis, exigiu-se concentração e diminuição do ritmo. Entendi que certos livros têm de ser respirados - e que esta tese ou carta ainda não terminou de ser escrita (como terminar?). Haverá um método que ensine a pôr um fim em tudo? Que ensine a transformar experiência em escrita? Ora, a escrita é o pó que sobra da batalha. Mais uma vez, Nietzsche sopra: "Deve-se falar somente quando não se pode calar; e falar somente daquilo que se superou - tudo o mais é tagarelice, 'literatura', falta de disciplina." 335 No entanto, nada mais próprio ao nosso destino ocidental do que tais assombros: o escrito é um morto, mas um morto que se presta a comunicar. A esse rastro sempre nos dobramos, impotentes.

\footnotetext{
331 DRUMMOND. "O mito", in A rosa do Povo, 1945.

332 "Passagem do ano", in Claro enigma, 1951.

${ }^{333} \mathrm{Idem}$.

334 Poema póstumo de Celan, em tradução portuguesa de João Barrento na edição: A morte é uma flor. Lisboa: Cotovia, 1998. No original: ,Jetzt wächst dein Gewicht um alles Leichte, / jetzt entlarvst du das Nämliche ohne Namen, / jetzt schickst du die silbenstechenden Dampfhämmer unter den Sporn dessen, der hinwegsetzt über das heckige Lisholz, / jetzt schreibst du.“ (Die Gedichte aus dem Nachlass. Frankfurt am Main: Suhrkamp, 1997).

${ }^{335}$ NIETZSCHE, Friedrich. Humano demasiado bumano II, prefácio, \} 1 .
} 
Nas linhas seguintes, finalizo com um breve relato dessa viagem, de seus objetivos estranhos e inquietantes (unheimlich), da pesquisa pelo fantásmico, desterrante que há no pensamento de certos autores da língua alemã. Relato de uma leitura desconcertante para alguém que desembarca da perspectiva solar, brasileira. Foi partindo desta perspectiva que constatei: não nos é mais permitido ter a idade da razão - temos antes a idade de uma razão que nos anoitece.

Fui para a Alemanha para estudar esta palavra, uma única palavra: das Unheimliche. Ela não existe em minha língua, sou estrangeira a ela e sempre serei. Mesmo para seus compatriotas (se é que se pode ter uma palavra como compatriota), ela soa estranha, quando soa. Unheimlich é uma dessas palavras mudas, que se fala no cotidiano sem prestar atenção no que ela evoca. Posso dizer simplesmente como adjetivo: o dia está unheimlich nublado; ou amanheci unheimlich mal-humorada; ou ainda que um livro é unheimlich complicado. Foi esta palavra que me levou para lá. Não falo de um conceito (Begriff) ou sistema filosófico que figure nos catálogos bibliográficos e nas prateleiras dos fabulosos arquivos que existem por toda parte na Alemanha. Não existe teoria sobre das Unheimliche, palavra que além de muda é quase invisível, pois ocupa no máximo entrelinhas, descrições fugidias ou notas de rodapé. Isso não quer dizer não houve alemão que não ousasse enfrentá-la: Hölderlin consagrou algumas exuberantes linhas a essa estranheza; também Nietzsche, Schopenhauer, Heidegger, Freud. E inclusive gente de outras terras. Mas isso não faz de Unheimlich uma teoria; nada pode fazer dela uma teoria. Unheimlich pode ser o maravilhoso - que de tão maravilhoso causa assombro, que de tão assombroso tira o chão, e que de tão desterrante abisma. E ali, no abismal, o homem faz morada. Unheimlich é um lar ou uma terra, mas uma terra que treme e algumas vezes engole quem nela pisa. É também a relativização de todo pisar, de todo impor-se humano verticalmente sobre o planeta. Como no drama de Édipo: o herói tem os pés inchados, tem a ferida justamente nos membros que deveriam lhe permitir 
estabilidade sobre o chão. O abismo de Édipo não está em sua pátria, mas em seus próprios pés.

Abissal, portanto unheimlich, é a condição humana sobre a terra. Heim é a terra mesma, o lugar pátrio, familiar, lar, sentir-se em casa. Heim-lich, por estar incrustado no familiar, é o íntimo, o secreto. Por fim, Un-heim-lich é a secreção: o que deveria ficar guardado, mas escapa; é a negação ou violação de toda familiaridade; exposição monstruosa ao estranho. E nisso há assombro suficiente: assombro da desmesura, do excesso de luz, da cegueira de quem acaba de sair da caverna. Unheimlich é a descoberta do secreto e seu inevitável secretar; não tem nada de poro, mas muito de ferida.

Nem tudo está digerido. 


$$
\text { III - Bibliografia }
$$




\section{GERAL}

ANDERS, Günther. Die Antiquiertheit des Menschen 1: über die Seele im Zeitalter der zweiten industriellen Revolution. Munique: C. H. Beck, 1956.

Die Antiquiertheit des Menschen 2: ̈̈ber die Zerstörung des Lebens im Zeitalter der dritten industriellen Revolution. Munique: C. H. Beck, 1980. 1984.

Menschen obne Welt. Schriften zur Kunst und Literatur. Munique: C. H. Beck,

1989.

Wenn ich verzweifelt bin, was geht's mich an? (1977). Frankfurt: Campus,

BAITELLO Jr., Norval. A era da iconofagia. São Paulo: Hacker, 2005.

BAITEllo, N., Contrera, M. \& Menezes. J. E. (org.). Os meios da incomunicação. São Paulo: Annablume, 2005.

BATAILLE, Georges. O erotismo: o proibido e a transgressão. Lisboa: Moraes, 1968.

- A experiência interior. São Paulo: Ática, 1992.

BENJAMIN, Walter. Medienästhetische Schriften. Frankfurt am Main: Suhrkamp, 2002.

Das Passagenwerk. Gesammelte Schriften, vol. V. Frankfurt: Suhrkamp, 1982.

."Der destruktive Character". In: Gesammelte Schriften, IV, p. 396-398.

Tradução brasileira em volume organizado por Willi Bolle: "O cartáter destrutivo", In: Documentos de cultura, documentos de barbárie. São Paulo: Cultrix, 1986.

- Obras escolbidas III. Charles Baudelaire, um lírico no auge do capitalismo. São Paulo: Brasiliense, 1989.

BLANCHOT, Maurice. L'intretien infini. Paris: Gallimard, 1969.

La communauté inavouable. Paris: Minuit, 1983.

BRETON, Philippe. L'utopie de la communication. Paris: Découverte, 1992.

BUDELLMANN, Felix. The language of Sophocles: communality, communication and involvement. Cambridge: Cambridge Univ. Press, 2000.

CHAUI, Marilena. Simulacro e poder: uma análise da mídia. São Paulo: Fundação Perseu Abramo, 2006.

DELEUZE, Gilles. Lógica do sentido (1969). São Paulo: Perspectiva, 1998.

DERRIDA, Jacques. La voix et le phénomène. Paris: Puf, 1967.

. Marges - de la philosophie. Paris: Minuit, 1972.

Éperons: les styles de Nietasche. Paris: Flammarion, 1978.

Otobiographies: l'enseignement de Nietzsche et la politique du nom propre. Paris:

Galilée, 1984.

Khôra. Paris: Galilée, 1993. 
. Apories: mourir - s'attendre aux limites de la vérité. Paris: Galilée, 1996.

L’animal que donc je suis. Paris: Galilée, 1999.

"Hospitality". In: Acts of religion. Nova York: Routledge, 2002.

DIELS, Hermann (Org.), KRANZ, Walther (Ed.). Fragmente der Vorsokratiker. Zürich/Hidessheim: Weidmann, 1989.

FASSLER, Manfred. Erdachte Welten: die mediale Evolution globaler Kulturen. Wien: Springer Verlag, 2005.

Was ist Kommunikation? (völlig überarbeitete und erneiterte Neuauflage).

München: W. Fink Verlag, 2003.

Menschenbilder. München, 2000.

FLUSSER, Vilém. Kommunikologie. Frankfurt am Main: Fischer, 1998.

Bodenlos: eine philosophische Antobiographie. Düsseldorf: Bollmann, 1992. . Lingua e realidade (1963). São Paulo: Annablume, 2004.

Escrituras, 2002.

. Da religiosidade: a literatura e o senso de realidade (1965). São Paulo:

FREUD, Sigmund. Das Unheimliche (1919h). In: Studienausgabe, vol. 4. Frankfurt: Fischer, 1970.

HAAR, Michel. Nietzssche et la métaphysique. Paris: Gallimard, 1993.

HEGEL, Georg W. F. Cursos de estética. Vol. IV. Trad. Marco Aurélio Werle \& Oliver Tolle. São Paulo: Edusp, 2004.

HEIDEGGER, Martin. "Die griechische Deutung des Menschen in Sophokles' Antigone", (1942). In: Gesamtausgabe, Band 5. Frankfurt am Main: Vittorio Klostermann, 1984. . Brief über den Humanismus, (1946). In: Gesamtausgabe, Band 12. . Essais et conférences. Paris: Gallimard, 1954.

. Chemins qui ne mènent nulle part (Holzwege). Paris: Gallimard, 1962. . O que é metafísica? Trad. Ernildo Stein. São Paulo: Duas Cidades, 1969. " "La question de la technique". In: Essais et conférences. Trad. André Préau. Paris: Gallimard, 1958.

Einführung in die Metaphysik (1953). Tübingen: Max Niemeyer, 1987. Edição brasileira: Introdução à metafísica. Trad. Emmanuel Carneiro Leão. Rio de Janeiro: Tempo Brasileiro, 1978. 1995.

Lingua de tradição e lingua técnica. Trad. Mário Botas. Lisboa: Passagens,

JÄGER, Werner. Paideia: die Formung des griechischen Menschen [1933-1973]. Berlin: Walter de Gruyter, 1989.

KAMERBEEK, J. C. The plays of Sophocles: commentaries on The Antigone. Leiden: E. J. Brill, 1978. 
KAMPER, Dietmar. Zur Soziologie der Imagination. Munique/Viena: Carl Hanser, 1986. Unmögliche Gegenwart. Zur Theorie der Phantasie. Munique: Wilhelm Fink, 1995.

O trabalho como vida. Trad. Peter Naumann e Norval Baitello Jr. São Paulo: Annablume, 1998.

Imanência dos media e corporeidade transcendental. Oito postos de observação para um futuro medial. Trad. Ciro Marcondes filho. São Paulo, 1998.

- As máquinas são tão mortais quanto as pessoas. Uma tentativa de excluir o telemático do pensamento. Trad. Ciro Marcondes Filho. São Paulo, 1998.

KOFMAN, Sarah. Comment s'en sortir? Paris: Galilée, 1983.

. Camera obscura: de l'idéologie. Paris: Galilée, 1973.

Fayard, 1973.

"Un philosophe unheimlich: essai sur Jacques Derrida". In: Ecarts.

. Nietzsche et la scène philosophique. Paris: Galilée, 1986.

. Paroles suffoquées. Paris: Galilée, 1987.

. Socrate(s). Paris: Galilée, 1989.

. Explosion I: De l'Ecce Homo de Nietasche. Paris: Galilée, 1992.

. Explosion II: Les enfants de Nietzsche. Paris: Galilée, 1993.

Le mépris des juifs: Nietzsche, les juifs, l'antisémitisme. Paris: Galilée, 1994.

. L'imposture de la beauté (póstumo). Paris: Galilée, 1995.

KRISTEVA, Julia. Soleil noir: dépression et mélancolie. Paris: Gallimard, 1987.

KROKER, Arthur \& Weinstein, Michael A. Data Trash. The Theory of the Virtual Class. New York: St. Martin's Press, 1994.

LOMBARDO, Giovanni. «Sublime et deinótès dans l'Antiquité gréco-latine ». In: Revue Philosophique de la France et de l'Étranger. Tome CXCIV. Paris: P.U.F., 2003.

MARCONDES Filho, Ciro. O escavador de silêncios: formas de construir e desconstruir sentidos na comunicação. São Paulo: Paulus, 2004. . Até que ponto, de fato, nos comunicamos? São Paulo: Paulus, 2004.

MARTON, Scarlett Z. "Em busca do discípulo tão amado. Uma análise conceitual do prólogo de Assim falava Zaratustra”. In: Impulso - revista de ciências humanas da Unimep, número 28. Piracicaba, 2001.

MATOS, Olgária C. F. O iluminismo visionário: Benjamin, leitor de Descartes e Kant. São Paulo: Brasiliense, 1993.

. "Imagens sem objeto". In: Rede imaginária. (org. Adauto Novaes). São Paulo: Companhia das Letras, 1991.

História viajante: notações filosóficas. São Paulo: Studio Nobel, 1997.

NANCY, Jean-Luc. La communauté désoeuvré (nouvelle édition, révue et augmenté).

Paris: Christian Bourgois, 1999. 
L'intrus. Paris: Galilée, 2000.

NIETZSCHE, Friedrich. Werke. Kritische Studienausgabe. Edição organizada por Colli e Montinari. Berlim: Walter de Gruyter \& Co., 1967-78.

Obras incompletas. Coleção os Pensadores. Trad. Rubens Rodrigues Torres Filho. São Paulo: Abril Cultural, 1974.

O nascimento da tragédia: ou helenismo e pessimismo (1872). Trad. J. Ginsburg. São Paulo: Companhia das Letras, 1992.

La philosophie à l'époque tragique des grecs. Trad. Michel Haar, Marc Launay. Paris: Gallimard, 1997.

Humano, demasiado humano (1878). Trad. Paulo César de Souza. São Paulo: Companhia das letras, 2000.

- Aurora (1881/1887). Trad. Paulo César de Souza. São Paulo: Companhia das Letras, 2004.

- A gaia ciência (1881/1887). Trad. Paulo César de Souza. São Paulo: Companhia das Letras, 2001.

- Assim falou Zaratustra (1883-1885). Trad. Mário da Silva. Rio de Janeiro: Brasiliense, 1986.

Além do bem e do mal (1886). Trad. Paulo César de Souza. São Paulo: Companhia das Letras, 1993.

Genealogia da moral (1887). Trad. Paulo César de Souza. São Paulo: Companhia das Letras, 1998.

. Crépuscule des idoles (1888). Trad. Jean-Claude Hémery. Paris: Gallimard, 1998.

Ecce homo (1888). Trad. Paulo César de Souza. São Paulo: Companhia das Letras, 1995.

PÁL PELBART, Peter. Vida capital: ensaios de biopolitica. São Paulo: Iluminuras, 2003.

PORCHAT PEREIRA, Oswaldo. Vida comum e ceticismo. São Paulo: Brasiliense, 1980.

REINHARDT, Karl. Sophokles. Frankfurt am Main: Vittorio Klotermann, 1976.

ROSENFIELD, Kathrin H. Antígona - de Sófocles a Hölderlin. Porto Alegre: L\&PM, 2000.

ROSSET, Clément. Logique du pire. Paris: P.U.F., 1971.

SERRES, Michel. Hermès I: la communication. Paris: Minuit, 1969. Les cinq sens: philosophie des corps mêlés I. Paris: Grasset, 1985.

SEXTUS EMPIRICUS. Esquisses pirrhoniennes. Trad. Pierre Pellegrin. Paris: Seuil, 1997.

SFEZ, Lucien. Critique de la communication. Deuxième édition. Paris: Seuil, 1990.

SLOTERDIJK, Peter. Regeln für den Menschenpark. Frankfurt am Main: Suhrkamp, 1999. 
VERNANT, Jean-Pierre. Les origines de la pensée grecque. Paris: P.U.F., 1962. . Mythe et pensée chez. les grecs: études de psychologie historique [1965]. Paris: La découverte, 1996. . Mythe et societé en Grèce ancienne [1974]. Paris: La découverte, 2004.

L'individu, la mort, l'amour: soi même et l' autre en Grèce ancienne. Paris: Gallimard, 1988.

VERNANT, Jean-Pierre \& VIDAL-NAQUET, Pierre. Mythe et tragédie en Grèce ancienne. Paris: La découverte, 1972.

WOLTON, Dominique. Penser la communication. Paris: Flammarion, 1997.

\section{POESIA}

DRUMMOND de ANDRADE, Carlos. Poesia completa. Volume único. São Paulo: Nova Aguilar, 2002.

CELAN, Paul. Werke. Frankfurt am Main: Suhrkamp, 1997. A morte é uma flor. Trad. João Barrento. Lisboa: Cotovia, 1998.

ÉLUARD, Paul. Oeuvres complètes. Paris: La Pléiade, 1968.

* ObSERVAÇÃo: os trechos de obras estrangeiras citadas ao longo da tese, quando sem referência a traduções brasileiras, foram por mim traduzidos e são de minha inteira responsabilidade. [DNO] 